\title{
Avaliação do periodonto de sustentação após a aplicação de forças ortopédicas, em ratos diabéticos
}

Tese apresentada à Faculdade de Odontologia de Ribeirão Preto da Universidade de São Paulo, para a obtenção do Título de Doutora em Ciências.

Programa: Odontopediatria

Área de Concentração: Odontopediatria

Orientadora: Profa. Dra. Maria Bernadete Sasso Stuani

Ribeirão Preto 


\section{FICHA CATALOGRÁFICA}

Okada, Elaine Machado Pingueiro

Avaliação do periodonto de sustentação após a aplicação de forças ortopédicas, em ratos diabéticos. Okada, Elaine Machado Pingueiro, Ribeirão Preto, 2018.

141p.; il.; $30 \mathrm{~cm}$

Tese de Doutorado apresentada à Faculdade de Odontologia de Ribeirão Preto da Universidade de São Paulo - Área de concentração: Odontopediatria.

Orientadora: Stuani, Maria Bernadete Sasso

1. Diabetes mellitus. 2. Movimentação Ortodôntica. 3. Remodelação óssea, 4. Expansão Rápida da Maxila. 5. Ligamento Periodontal. 


\section{FOLHA DE APROVAÇÃO}

OKADA, EMP. Avaliação do periodonto de sustentação após a aplicação de forças ortopédicas, em ratos diabéticos.

Tese apresentada à Faculdade de Odontologia de Ribeirão Preto da Universidade de São Paulo, para a obtenção do Título de Doutora em Ciências.

Área de Concentração: Odontopediatria.

Data da defesa:

\section{BANCA EXAMINADORA}

Prof. Dr.

Instituição:

Julgamento: Assinatura:

Prof. Dr.

Instituição:

Julgamento: Assinatura:

Prof. Dr.

Instituição:

Julgamento: Assinatura:

Prof. Dr.

Instituição:

Julgamento:

Assinatura:

Prof. Dr.

Instituição:

Julgamento: Assinatura: 

DADOS CURRICULARES

\section{ELAINE MACHADO PINGUEIRO OKADA}

Nascimento: 28 de outubro de 1985- Ribeirão Preto- SP.

Filiação: $\quad$ Ester Vieira Machado Pingueiro

Arlindo Pingueiro

2005-2008: $\quad$ Curso de Graduação

Faculdade de Odontologia de Araraquara - FOAr. Universidade

Estadual Paulista Júlio de Mesquita Filho- UNESP.

2010-2010: Curso de Extensão universitária: Atendimento Odontológico a Pacientes Especiais

Faculdade de Odontologia de Ribeirão Preto da Universidade de São Paulo

2009-2012: $\quad$ Curso de Pós-Graduação (Mestrado) em Odontologia

Área de Concentração: Odontopediatria

Faculdade de Odontologia de Ribeirão Preto da Universidade de São Paulo

Dissertação: Efeito do laser de baixa potencia após a expansão rápida da maxila na ativação de regiões cerebrais relacionadas à nocicepção.

Orientadora: Profa. Dra. Maria Bernadete Sasso Stuani

Bolsa: CAPES

2014-2018: Curso de Pós-Graduação (Doutorado) em Odontologia Área de Concentração: Odontopediatria

Faculdade de Odontologia de Ribeirão Preto da Universidade de São Paulo

Tese: Avaliação do periodonto de sustentação após a aplicação de forças ortopédicas, em ratos diabéticos.

Orientadora: Profa. Dra. Maria Bernadete Sasso Stuani

Bolsa: CAPES 

Dedicatória 



\title{
Dedico este Trabalho
}

\author{
A Deus, Aba Pai!
}

\section{Obrigada pelo sopro da vida! Pelo seu grande amor para comigo!}

"SENHOR, tu me sondaste, e me conheces.

Tu sabes o meu assentar e o meu levantar; de longe entendes o meu pensamento. Cercas o meu andar, e o meu deitar; e conheces todos os meus caminhos. Não havendo ainda palavra alguma na minha língua, eis que logo, ó Senhor, tudo conheces. Tu me cercaste por detrás e por diante, e puseste sobre mim a tua mão. Tal ciência é para mim maravilhosíssima; tão alta que não a posso atingir. Para onde me irei do teu espirito, ou para onde fugirei da tua face? Se tomar as asas da alva, se habitar nas extremidades do mar,

Até ali a tua mão me guiará e a tua destra me susterá.

Nem ainda as trevas me encobrem de ti; mas a noite resplandece como o dia; Eu te louvarei, porque de um modo assombroso, e tão maravilhoso fui feito; maravilhosas são as tuas obras, e a minha alma o sabe muito bem.

Os meus ossos não te foram encobertos, quando no oculto fui feito, e entretecido nas profundezas

da terra.

E quão preciosos me são, ó Deus, os teus pensamentos! Sonda-me, ó Deus, e conhece o meu coração; prova-me, e conhece os meus pensamentos. E vê se há em mim algum caminho mau, e guia-me pelo caminho eterno."

Salmos: 139 

$\mathcal{A}_{\text {gradecimentos }} \boldsymbol{E}_{\text {speciais }}$ 



\section{AgRAdECIMENTOS EsPECIAIS}

Aos meus pais, Ester e Arlindo!

"O justo anda na sua integridade, Felizes são seus filhos depois dele."

Provérbios: 20:7

Pai, tenho orgulho do senhor! Fachada de sério, mas um coração doce!!! Sei que perder a mãe tão cedo, trabalhar na roça, cuidar dos irmãos, ir atrás do sonho de trabalhar na cidade, correr atrás de empregos, trabalhar fora (lembro-me que quando o senhor voltava, ganhávamos papel de carta- temos uma linda coleção deles!!!)... e chegar até aqui... não foi nada fácil...

Mãe, a senhora é linda por dentro e por fora! Logo que terminou o magistério, começou a lecionar... aliás, a senhora o faz com excelência!!!! A senhora nunca parou de estudar! e sempre nos estimulou a fazer o mesmo!!! Recordo da senhora indo trabalhar o dia todo e chegava correndo pra pegar o ônibus que a levaria pra outra cidade pra fazer faculdade a noite... por vezes o papai precisava correr atrás do ônibus, por vezes a sra o perdia... obrigada por ter abrido mão de outras possibilidades de emprego pra que nós não perdêssemos de estudar onde a sra dava aula... recordo da senhora costurando meu travesseiro altas horas da noite porque sem ele eu não dormia...obrigada pelos incríveis bolos!!!

Sou grata a Deus por ter escolhido a dedo pessoas tão especiais para serem meus pais! Agradeço pelas noites mal dormidas, pelas refições não terminadas, pelos ensinos e correções, pelos eforços que fizeram pra nos darem sempre o seu melhor!!! Agradeço por vocês serem exemplo de caráter e esforço, por terem me dado a Raquel por irmã maravilhosa companhia, por nos amarem muito, por demonstrarem carinho nas pequeninas coisas, por nos ensinarem a trilhar no caminho do Senhor e na sua palavra! Amo muito vocês!

À minha querida irmã Raquel Angélica! Obrigada por repartir sua vida comigo! As coisas não teriam o mesmo brilho sem a sua companhia! Você é uma pessoa incrível, de distinas e numerosas habilidades, e um coração imenso! Sei que por vezes sou egosísta e por te amar tanto, quero você sempre "grudada" em mim! é porque em meio às nossas temosias e brigas, você me entende!!!! Vibrei com cada fase sua, cada etapa!!! Estou aqui! Sou sua torcida, sempre!!!!! 
Ao meu marido Adriano! Meu príncipe, eu te escolhi, e te escolho, sempre!!!!

Sei que no meio da sua trajetória, muita coisa foi diferente do que você pensou, mas agradeço a Deus pelo cursinho... onde te conheci! Você é meu melhor amigo! Homem de incríveis qualidades, sábio, inteligente, de caráter, amoroso, responsável, lindo! E um pai fenomenal!!! Tenho muito orgulho de você!!!!! Sou sua maior torcida, pode acreditar!!!! E tenho muito orgulho da linda família que formamos!!!

Obrigada por repartir comigo os pequenos detalhes da vida!!!!! O pão de cada dia... A vida não seria tão bela sem seu amor!!!! Obrigada por sempre me apoiar!!! Te amo!!

"Se alguém prevalecer contra um, os dois lhe resistirão; e o cordão de três dobras não se quebra tão depressa.” Eclesiastes 4:12

Ao nosso pequeno príncipe Timóteo, presente de Deus, que veio rechear nossa família com muito sabor e cor, e dar mais sentido e motivo às nossas vidas!!! "Aos olhos do Pai, você é uma obra prima..."

Você foi planejado e amado a cada segundo, querido filho, desde meu ventre!! Estou aprendendo contigo! Estou longe de ser perfeita, mas o amor que sinto por você é gigante e me faz sempre querer ser melhor! Estarei sempre aqui, fazendo meu melhor, orando por você e te amando!

À tia Gema, obrigada por seus conselhos, carinho e apoio desde que eu era "catatau"! a senhora é importante em minha vida!!! Te amo mto!

Ao tio Estevão, que mesmo longe, está por perto, orando e trazendo palavras de ânimo!

À dona Cecília e ao saudoso seu Cyro, meus sogros. Por terem me dado o Adriano e por sempre nos apoiarem com amor! Aos meus cunhados Susana, Johny, e Denise, pela convivência harmoniosa e carinho! Aos meus sobrinhos, Raphael - tenho muito orgulho de você, e Viktor Mateus, pequenino! Amo vocês!

A todos os meus familiares, tios e primos! Gostaria de vê-los com mais frequência!!!! vocês são importantes em minha vida!!!!!!

Querida família, obrigada por vocês sempre sonharem comigo, e me darem suporte pra galgar estes sonhos!!!! Amo muito vocês! 
À minha orientadora, Profa. Dra ${ }^{\mathrm{a}}$. Maria Bernadete Sasso Stuani, por ter me acolhido quando na USP cheguei, com muitos sonhos na mão, mas sem conhecer ninguém!! Obrigada por me deixar conhecer um pouquinho da senhora, um ser humano tão peculiar e tão especial! Obrigada pelo conhecimento compartilhado, por ser uma segunda mãe aos que a cercam, pelos conselhos, correções, por participar de minha vida desde 2009 e por nunca ter me deixado desistir!!! Obrigada por usufruir da equipe da "Berna”!! Minha eterna gratidão!

À minha amiga Maya Manfrin Arnez!!! Ainda bem que "esbarrei em você” no meu mestrado! Agradeço a Deus por sua amizade! por me acolher como irmã mais nova, não só "de pesquisa"!!! Obrigada pelas boas conversas, conselhos, experiências (agora com meu pequenino)! por ter me dado muita força pra não desistir do doutorado! Sem sua ajuda eu não estaria aqui!! Você, a linda Alice e o Francisco estão em minhas orações! Você mora no meu coração "Maria”!!!!!!

Aos meus amigos e companheiros de equipe Patrícia, Gabriel, Kelly, Larissa e Paula, Paola por compartilharem comigo não só pesquisas e aprendizado, mas de suas vidas, com dias mais agitados e turbulentos, bem turbulentos, e outros dias alegres! Grata por ter tido a oportunidade de trabalhar com vocês! À Paola, com quem embora tenha sido menor o contato, demostrou ser uma pessoa incrível!!

Às alunas de Iniciação científica Laura e Mariana, que me acompanharam dias a fio enquanto eu trabalhava no microscópio e pensava no quartinho do Timóteo! Obrigada pelo apoio e por sonharem comigo!

À minha amiga Érika Calvano Kuchler! Por vezes me perguntava como dava para ser "pós-doc”, esposa, ninja na cozinha, professora talentosa, crânio nos artigos e pesquisas e ainda ter tempo pros amigos!!!! Você é especial! Obrigada pela ajuda! Boa sorte em sua trajetória!!! 

Agradecimentos 



\section{AgRACEDIMENTOS}

À Faculdade de Odontologia de Ribeirão Preto da Universidade de São Paulo, na pessoa da atual Diretora Profa. Dra. Léa Assed Bezerra da Silva e do Vice-Diretor Prof. Dr. Arthur Belém Novaes Júnior.

À Coordenação do Curso de Pós-Graduação da Faculdade de Odontologia de Ribeirão Preto da Universidade de São Paulo, na pessoa do Prof. Dr. Manoel Damião de Sousa Neto.

Aos Professores do Departamento de Clínica Infantil da Faculdade de Odontologia de Ribeirão Preto da Universidade de São Paulo, Prof. Dr. Adílson Tomasin, Profa. Dra. Aldevina Campos Freitas (que ama o que faz, exemplo pra vida), Profa. Dra. Alexandra Mussolino de Queiroz, Profa. Dra. Andiara De Rossi Daldegan, Prof. Dr. Fábio Lourenço Romano, Prof. Dr. Fabricio Kitazono de Carvalho, Prof. Dr. Francisco Wanderley Garcia de Paula e Silva, Prof. Dr. José Tarcísio Lima Ferreira, Profa. Dra. Kranya Victoria Díaz Serrano, Profa. Dra. Léa Assed Bezerra da Silva, Profa. Dra. Maria da Conceição Pereira Saraiva, Profa. Dra. Maria Cristina Borsatto, Profa. Dra. Mírian Aiko Nakane Matsumoto, Prof. Dr. Paulo Nelson Filho e Profa. Dra. Raquel Assed Bezerra Segato, à saudosa Professora do Departamento de Morfologia, Estomatologia e Fisiologia da Faculdade de Odontologia de Ribeirão Preto da Universidade de São Paulo Profa. Dra. Mamie Mizusaki Iyomasa - a senhora deixou um lindo legado!!!

Aos demais pós-graduandos do Programa de Pós-Graduação em Odontopediatria pelas conversas e convivência sempre tão agradável. Por todo carinho durante à gestação do Timóteo, pelos mimos e preocupações!!

À Michelli Cristina Leite Rovanholo, pela simpatia, amizade, ajuda e paciência, muita paciência ainda bem que você existe em nossas vidas! Obrigada!!

Aos funcionários do Departamento de Clínica Infantil da Faculdade de Odontologia de Ribeirão Preto da Universidade de São Paulo, Fátima Aparecida Jacinto Daniel, Filomena Leli Placciti, Matheus Morelli Zanela, Marco Antônio dos Santos ao saudoso Sr. Carmo Eurípedes 
Terra Barretto e aos funcionários do Centro de Formação de Recursos Humanos no Atendimento Odontológico a Pacientes Especiais Carolina Paes Torres Mantovani, Fátima Aparecida Rizoli e Benedita Viana Rodrigues, à especialista de laboratório e amiga Marilia Pacífico Lucisano pela amizade e atenção que sempre manifestaram!

Aos funcionários do Biotério da Faculdade de Odontologia de Ribeirão Preto da Universidade de São Paulo, Aline Aparecida Ferraresi Tiballi, Antonio Sérgio Aparecido Mesca e Antônio Masssaro pela amizade, boa convivência, ajuda, disponibilidade e pelos cuidados prestados aos animais durante todo o período experimental desta pesquisa. Vocês foram muito importantes para o andamento desta minha pesquisa!

Aos funcionários da Seção de Pós-Graduação da Faculdade de Odontologia de Ribeirão Preto da Universidade de São Paulo, Mary Possani Carmessano e Carlos Feitosa dos Santos pela cordialidade e atenção.

À Rose, pelo sorriso sempre estampado no rosto e disposição pra ajudar! Obrigada pelo apoio nessa reta final.

À Coordenação de Aperfeiçoamento de Pessoal de Nível Superior (CAPES) pela bolsa concedida.

Aos Professores da Banca, pela atenção dispensada na leitura desta dissertação.

A todos aqueles que não foram citados, mas contribuíram de alguma forma deste momento em minha vida. Muito obrigada! 
Resumo 



\section{RESUMO}

Okada, EMP. Avaliação do periodonto de sustentação após a aplicação de forças ortopédicas em ratos diabéticos. [Tese]. Ribeirão Preto. Faculdade de Odontologia de Ribeirão Preto da Universidade de São Paulo, Ribeirão Preto; 2018.

Introdução: Diabetes mellitus (DM) é uma desordem metabólica associada a diversas alterações sistêmicas e uma das características é afetar o metabolismo ósseo. As modificações teciduais induzidas pela força ortodôntica estão relacionadas à sua remodelação por ativação da reabsorção óssea alveolar no lado de pressão e conseqüente aposição óssea no lado de tração. Objetivo: avaliar o processo de remodelação do periodonto de sustentação através da análise imunohistoquímica e histológica após a aplicação da expansão rápida da maxila (ERM) em ratos sob estado diabético. Material e Métodos: Noventa ratos Wistar, machos, foram distribuídos aleatoriamente em seis grupos de estudo, contendo cada um, 15 animais: grupo C: animais não-diabéticos e sem expansão rápida da maxila (ERM); grupo DM: animais com diabetes mellitus (DM) induzidos por Streptozotocina (STZ); grupo ERM: animais com ERM; grupo DM+ERM: animais com DM + ERM; grupo DM+INS: animais com diabetes mellitus e tratados com insulina (INS); grupo DM+INS+ERM: animais com diabetes mellitus, tratados com insulina e realizada a ERM. Os animais foram submetidos à eutanásia 3, 7 ou 10 dias após a ERM. Foram realizadas análises histológicas qualitativas e imunoistoquímicas para avaliar a expressão da tríade protêica (TRAP, RANKL e OPG). Para as reações imunoistoquímicas foram realizadas análise qualitativa e semi quantitativa através da atribuição de scores para a intensidade da expressão das proteínas analisadas. Nos dados não paramétricos, foi utilizado o teste de Kruskal-Wallis e pós-teste de Dunn nas comparações $(p<0,05)$. Resultado: Em relação aos aspectos histológicos houve alteração na disposição das fibras colágenas, morfologia dos fibroblastos, quantidade de vasos sanguíneos e quantidade de tecido ósseo neo-formado caracterizado pelas linhas incrementais nos grupos ERM, DM+ERM e $\mathrm{DM}+\mathrm{INS}+\mathrm{ERM}$ comparado com seus respectivos grupos controle. Qualitativamente, a neoformação do osso alveolar dos ratos diabéticos foi menor quando comparado com os normais e, a alteração sistêmica diabetes melittus promoveu redução significativa na taxa de formação e maturação óssea. O grupo ERM mostrou os maiores valores para indicadores de osteoclastogênese (TRAP) nos períodos iniciais sendo que nos grupos diabéticos (DM+ERM e DM+INS+ERM), essa expressão foi maior nos períodos finais do experimento. O mesmo comportamento foi verificado com as proteínas de remodelação e neo-formação óssea (RANKL e OPG) óssea. Conclusão: A diabetes mellitus atrasou o processo de reparo do periodonto de sustentação e alterou o turnover ósseo. A insulina utilizada para o controle do diabetes melhoraram as respostas, mas não restabeleceram completamente os valores iniciais do grupo controle. Porém, apesar das diferenças qualitativas nas respostas teciduais do periodonto, a condição diabética em estado inicial mostrou pouco impacto clínico sobre o procedimento de movimentação dentária induzida.

Palavras-chave: diabetes mellitus, movimentação ortodôntica, remodelação óssea, expansão rápida da maxila, ligamento periodontal. 

Hastract 



\begin{abstract}
Okada, EMP. Evaluation of the support periodontium after the application of orthopedic forces in diabetic rats. [Thesis]. Ribeirão Preto. Dentistry School of São Paulo University, Ribeirão Preto, Brazil; 2018.
\end{abstract}

Introduction: Diabetes mellitus (DM) is a metabolic disorder associated with several systemic changes and one of the characteristics is to affect bone metabolism. Tissue modifications induced by orthodontic force are related to its remodeling by activation of alveolar bone resorption on the pressure side and consequent bone apposition on the traction side. Objective: To evaluate the remodeling process of the support periodontium through immunohistochemical and histological analysis after the application of rapid maxillary expansion (RME) in rats on diabetic state. Material and Methods: Ninety male Wistar rats were randomly assigned to six study groups, each containing 15 animals: GC: non-diabetic animals without rapid maxillary expansion (RME); GDM: animals with diabetes mellitus (DM) induced by Streptozotocin (STZ); GRME: animals with RME; GDM+RME: animals with DM + RME; GDM+INS: animals with DM, treated whit insulin; GDM+INS+RME: animals with DM, treated with insulin and RME. The animals were submitted to euthanasia 3,7 or 10 days after RME. Qualitative and immunohistochemical histological analyzes were performed to evaluate the expression of the protein triad (TRAP, RANKL and OPG). For the immunohistochemical reactions, qualitative and semi quantitative analysis were performed through the assignment of scores for the expression intensity of the analyzed proteins. The non-parametric data were used the Kruskal-Wallis test and Dunn post-test in the comparisons $(p<0.05)$. Results: In relation to the histological aspects, there was alteration in the collagen fibers, fibroblast morphology, number of blood vessels and quantity of neoformed bone tissue characterized by the incremental lines in the RME, DM+RME and DM+INS+RME groups, compared to their respective control groups. Qualitatively, the neoformation of the alveolar bone of the diabetic rats was smaller when compared to the normal ones, and the systemic alteration diabetes melittus promoted a significant reduction in the formation rate and bone maturation. The RME group showed the highest values for indicators of osteoclastogenesis (TRAP) in the initial periods, and this expression was higher in the diabetic groups (DM+RME and DM+INS+RME) in the final periods of the experiment. The same behavior was verified with bone remodeling and neoformation (RANKL and OPG) proteins. Conclusion: Diabetes mellitus delayed the periodontal repair process and altered bone turnover. Insulin used to control diabetes improved responses but did not completely restore control group initial values. However, in spite of the qualitative differences in the tissue responses of the periodontium, the diabetic condition in initial state showed little clinical impact on the induced tooth movement procedure.

Keywords: diabetes mellitus, orthodontic movement, bone remodeling, rapid maxillary expansion, periodontal ligament. 

Lista de Figuras 



\section{LISTA DE FIGURAS}

Figura 1- Esquema ilustrando o delineamento experimental do estudo e os procedimentos experimentais executados em seus respectivos

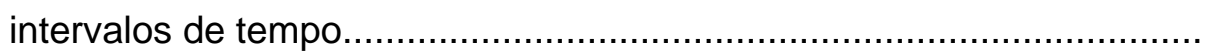

Figura 2- A- Fotografia do dispositivo ortodôntico utilizado, B- Animal posicionado na mesa operatória, C- espátula 7 utilizada na ERM, posicionada entre incisivos, D- dispositivo ortodôntico em posição, Eresina recobrindo o dispositivo ortodôntico.

Figura 3- Fotomicrografias dos Grupos controles, não submetidos à ERM (C, DM e DM+INS) de 3, 7 e 10 dias após o começo do período experimental: O - tecido ósseo, LP - ligamento periodontal com fibras colágenas, vasos sanguíneos e células, d - dente, seta- vaso sanguíneo hiperêmico. Coloração de HE e Masson.

Figura 4- Fotomicrografias do Grupo ERM, de 3, 7 e 10 dias pós aplicação da força: O - tecido ósseo, LP - ligamento periodontal com fibras colágenas, vasos sanguíneos e células, $\mathrm{d}$ - dente, * tecido inflamatório e áreas hemorrágicas, seta - osteoclastos. Coloração de HE e Masson.....

Figura 5- Fotomicrografias do Grupo DM+ ERM, de 3, 7 e 10 dias após aplicação da força: O - tecido ósseo, LP - ligamento periodontal com fibras colágenas, vasos sanguíneos e células, d - dente, *(preto) tecido inflamatório e *(branco) áreas hemorrágicas, seta osteoclastos. Coloração de HE e Masson...........................................

Figura 6- Fotomicrografias do Grupo DM+ INS+ ERM, de 3, 7 e 10 dias após aplicação da força: O - tecido ósseo, LP - ligamento periodontal com fibras colágenas, vasos sanguíneos e células, d - dente, seta osteoclastos. Coloração de HE e Masson.

Figura 7- Análise semi-quantitativa da expressão de TRAP nos diferentes grupos e períodos analisados. Expressão da mediana, amplitude interquartil, valores máximos e mínimos dos escores de imunorreatividade para TRAP ( $p<0,05$; Kruskal-Wallis, teste de Dunn). Os dados correspondem a 10 dias de experimento. ${ }^{*} p<0,05 \%$, ${ }^{* *} p<$ 0,01 . 
Figura 8- Análise semi-quantitativa da expressão de RANKL nos diferentes grupos e períodos analisados. Expressão da mediana, amplitude interquartil, valores máximos e mínimos dos escores de imunorreatividade para RANKL; $(p<0,05 ;$ Kruskal-Wallis, teste de Dunn). Os dados correspondem a 10 dias de experimento. * $p<0,05 \%$, ${ }^{* *}$ p 0,01

Figura 9- Análise semi-quantitativa da expressão de OPG nos diferentes grupos e períodos analisados. Expressão da mediana, amplitude interquartil, valores máximos e mínimos dos escores de imunorreatividade para OPG ( $p<0,05$; Kruskal-Wallis, teste de Dunn). Os dados correspondem a 10 dias de experimento. * $p<0,05 \%,{ }^{* *}$ p 0,01

Figura 10- Gráficos mostrando os escores para TRAP (A), RANKL (B) e OPG (C) dos grupos analisados. Fotomicorgrafias mostrando a aparência histológica da imunomarcação para TRAP (A1, A2 e A3); RANKL (B1, B2 e B3) e OPG (C1, C2 e C3). 


\section{$\mathcal{L}_{\text {istade }} \boldsymbol{T}_{\text {abelas e }} \boldsymbol{Q}_{\text {uadro }}$}





\section{LISTA DE TABELAS E QUADRO}

Tabela 1- Grupos experimentais, tempos, número de animais e procedimentos propostos.

Tabela 2- Avaliação glicêmica ( $\mathrm{mg} / \mathrm{dl})$ nos diferentes grupos de estudo e tempos de avaliação

Tabela 3- Avaliação do peso corporal (g) nos diferentes grupos de estudo e tempos de avaliação

Tabela 4- Avaliação do consumo hídrico $(\mathrm{mL})$ nos diferentes grupos de estudo durante todo o experimento

Quadro 1- Escore utilizado para descrever a intensidade da presença de imunomarcação das proteínas analisadas 

$\mathcal{L}_{\text {ista de }} \mathcal{A}_{\text {breviaturas, }} \mathcal{S}_{\text {iglase }} \mathcal{S}_{\text {imbolos }}$ 



\section{LISTA DE ABREVIATURAS, SIGLAS E SÍMBOLOS}

$\% \quad$ Expressa um valor em percentual

${ }^{\circ} \mathrm{C}: \quad$ Graus centígrados (Celsius)

ADA: American Diabetes Association

ANOVA: $\quad$ Análise de Variância

C Controle

CEUA Comissão de Ética no Uso de Animais

DNA: Ácido desoxirribonucleico

EDTA: Etileno-diamino-tetra-acético

DM: $\quad$ Diabetes mellitus

DM1: Diabetes mellitus tipo 1

DM2: $\quad$ Diabetes melitus tipo 2

ERM: $\quad$ Expansão rápida da maxila

FORP-USP Faculdade de Odontologia de Ribeirão Preto da Universidade de São Paulo

FID: $\quad$ Federação internacional de diabetes

g: $\quad$ Grama(s)

HE: Hematoxilina e eosina

IDF: International diabetes federation

INS: Insulina

Kg: $\quad$ Quilograma(s)

Laser Light amplification by stimulated emission of radiation (Amplificação da luz por emissão estimulada da radiação)

LP: $\quad$ Ligamento periodontal

$\mathbf{m g} / \mathbf{k g} \quad$ Miligrama por quilograma

mg: $\quad$ Miligrama(s)

$\mathrm{mL}: \quad$ Mililitro(s)

mm: $\quad$ Milímetro(s)

mm2 Milímetro quadrado

ng: Nanograma(s)

nm: Nanômetro(s)

OMS: Organização Mundial da Saúde

OPG Osteoprotegerina

$P \quad$ Valor- $p$

PBS Solução tampão fosfato salino

pH: Potencial hidrogeniônico 
RANK Receptor ativador do fator nuclear Kappa B

RANK-L Ligante do receptor ativador Kappa B

RNAm Ácido ribonucleico mensageiro

SBD: $\quad$ Sociedade Brasileira de Diabetes

STZ: $\quad$ Estreptozotocina

SUS: $\quad$ Sistema único de saúde

TRAP: fosfatase ácida resistente ao tartarato

WHO: World

$\mu \mathrm{L}: \quad$ Microlitro(s)

$\mu \mathrm{m}: \quad$ Micrômetro(s) 
$\mathcal{S}$

umário 



\section{SUMÁRIO}

1. INRODUÇÃO

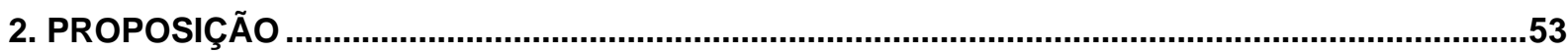

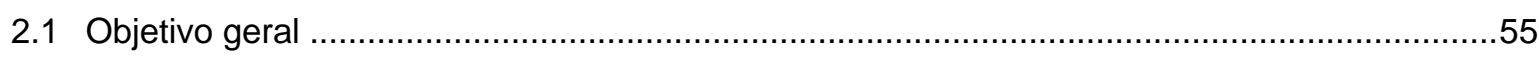

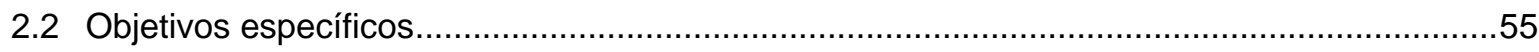

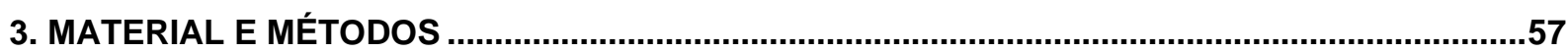

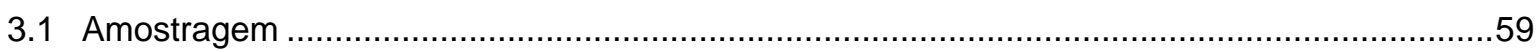

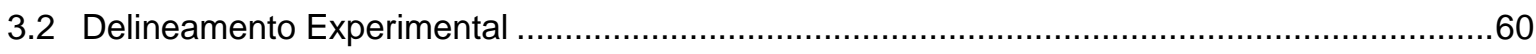

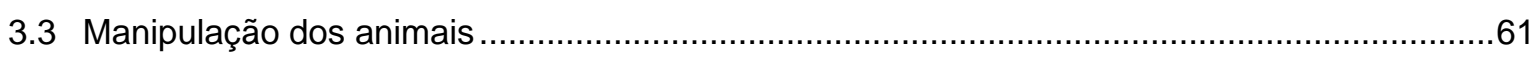

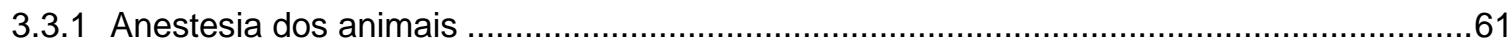

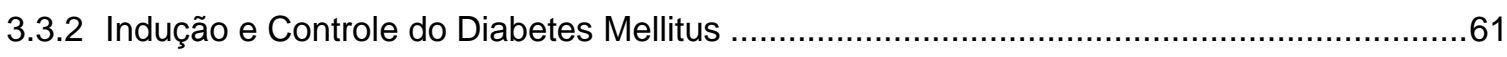

3.3.3 Procedimento de Expansão Rápida da Maxila e instalação de dispositivo ortodôntico ......62

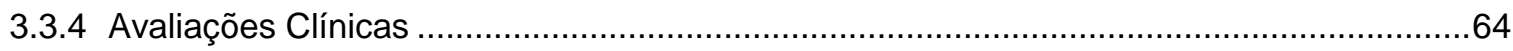

3.3.5 Eutanásia dos animais e coleta dos Espécimes ................................................................65

3.4 Preparo das peças para exame histológico e imunohistoquímico ............................................65

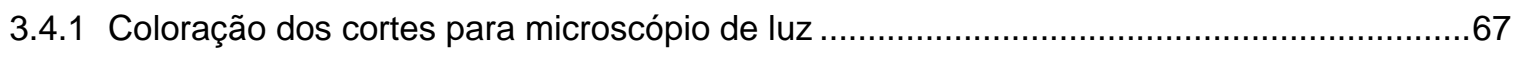

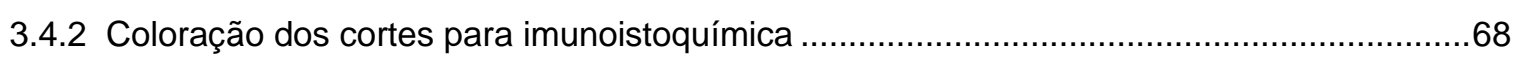

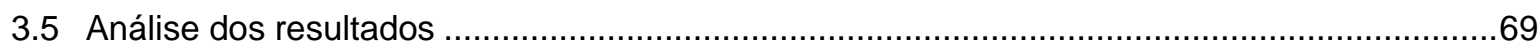

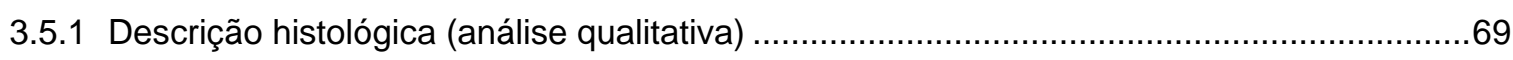

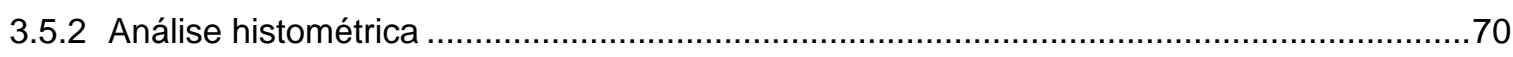

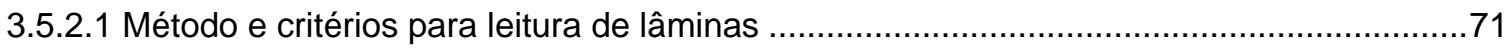

3.6 Precisão da Metodologia (Calibração do examinador) …….............................................. 72

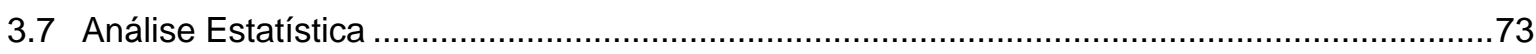

4. RESULTADOS

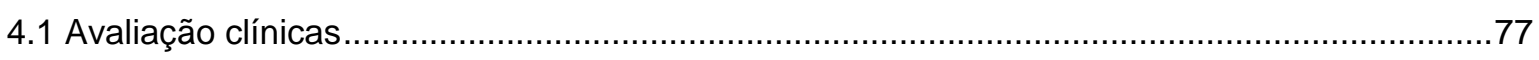

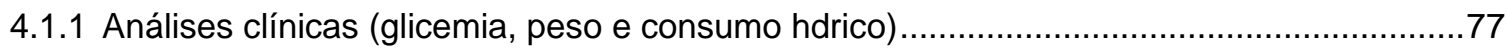

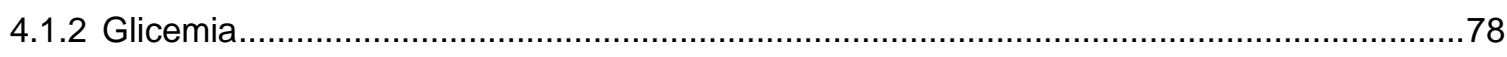

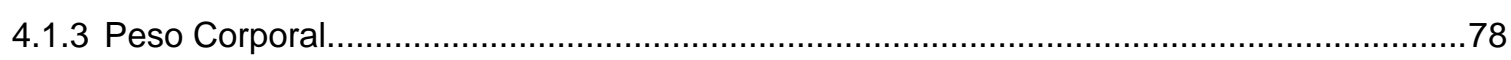

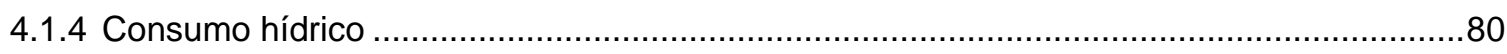

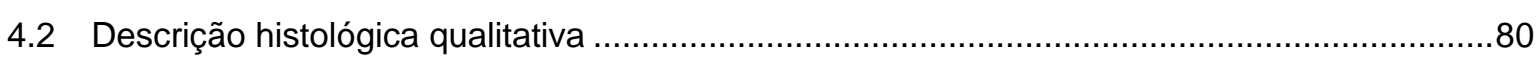

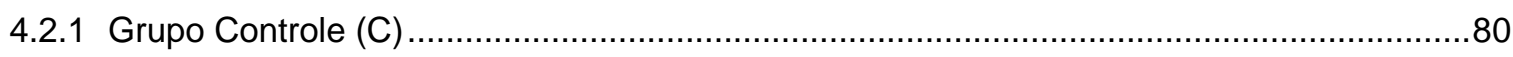

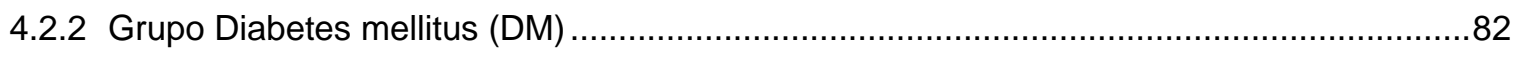

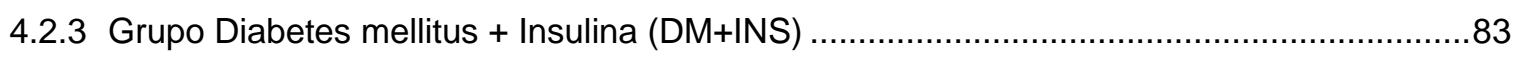

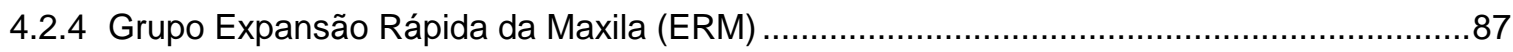

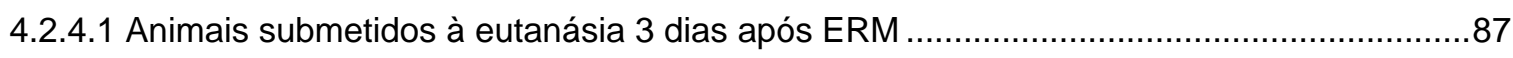

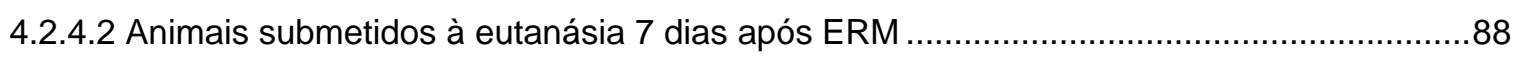

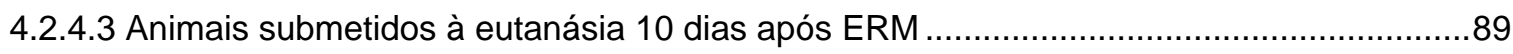

4.2.5 Grupo Diabetes mellitus + Expansão Rápida da Maxila (DM+ERM) .................................93

4.2.5.1 Animais DM submetidos à eutanásia 3 dias após ERM ..............................................93 
4.2.5.2 Animais DM submetidos à eutanásia 7 dias após ERM ……....................................... 94

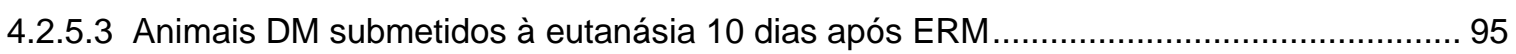

4.2.6 Grupo Diabetes mellitus + Insulina + Expansão Rápida da Maxila (DM+INS+ERM) ......... 99

4.2.6.1 Animais diabéticos tratados (INS), submetidos à eutanásia 3 dias após ERM................. 99

4.2.6.2 Animais diabéticos tratados (INS), submetidos à eutanásia 7 dias após ERM................ 99

4.2.6.3 Animais diabéticos tratados (INS), submetidos à eutanásia 10 dias após ERM ........... 100

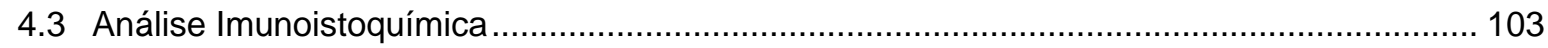

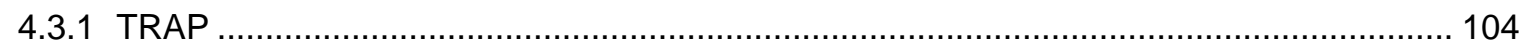

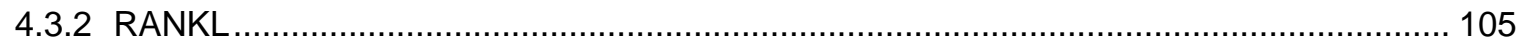

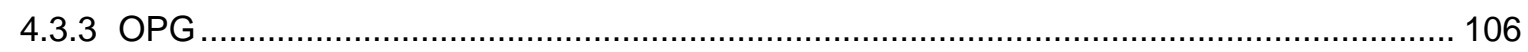

5. DISCUSSÃO

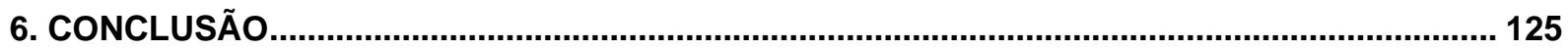

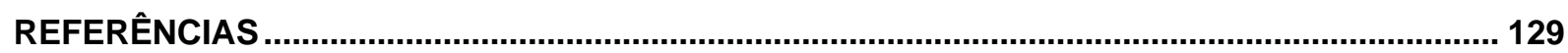

ANEXO 
1. Introdução 



\section{INTRODUÇÃO}

O Diabetes Mellitus (DM) é uma doença caracterizada pelo aumento da concentração plasmática de glicose no sangue de forma crônica, devido à deficiência da produção de insulina no pâncreas, ou à redução de sua ação, ou ambas (SBD, 2009; ADA, 2011, WHO, 2016). O DM é reconhecido pela Organização Mundial da Saúde (WHO, 2016) como uma importante causa de incapacidade e morte prematura. Quando o diabetes não é bem controlado, podem desenvolver complicações que ameaçam a saúde e põem em risco a vida. Complicações agudas são um importante contribuinte para a mortalidade, custos e baixa qualidade de vida (WHO, 2016).

Estimou-se que em 2017 havia 451 milhões de pessoas com diabetes no mundo (Cho et al., 2018) e em 2014, 422 milhões de adultos viviam com diabetes, em comparação a 108 milhões em 1980. A prevalência global de diabetes quase duplicou desde 1980 , passando de $4,7 \%$ para $8,5 \%$ na população adulta (WHO, 2016). Este crescimento vertiginoso pode ser explicado pelo aumento e envelhecimento populacional, seguido da prevalência específica relacionada a cada faixa etária, assim como ao tipo de dieta, estilo de vida, sedentarismo, obesidade e acesso ao tratamento médico (SBD, 2009; Danaei et al., 2011).

Desde 1991, visualizando a importância desta doença, a Federação Internacional de Diabetes (FID) vinculada a OMS criou o dia mundial de controle e prevenção do diabetes, celebrado no dia 14 de novembro. No Brasil o dia nacional do DM é comemorado no dia 27 de junho e há uma lei federal n 11.347/2006 que está em vigor desde 2007, que determina que pacientes diabéticos devem receber gratuitamente pelo Sistema Único de Saúde (SUS), os medicamentos necessários para o tratamento, assim como os materiais exigidos para a sua aplicação e a monitoração da glicemia capilar (glicosímetro). 
De acordo com a Organização Mundial da Saúde (OMS) e a Associação Americana de Diabetes (ADA) há quatro classes clínicas de diabetes, DM tipo 1 (DM1), DM tipo 2 (DM2), DM gestacional e outras formas específicas de diabetes devido a outras causas, tais como DM de origem genética, medicamentosa ou infecciosa (como algumas medicações para tratamento de HIV ou após transplante de órgãos). Além disso, a glicemia de jejum alterada e a tolerância à glicose diminuída não são consideradas entidades clínicas, mas são fatores de risco ao DM e à doenças cardiovasculares, sendo referidas como estágios pré-diabéticos (WHO, 1999; ADA, 2011).

O DM1 é caracterizado pela destruição parcial ou completa das células beta $(\beta)$ do pâncreas, o que gera a deficiência de insulina (5-10\% dos diabéticos). Esta categoria pode ser de origem autoimune ou idiopática. O DM2 caracteriza-se pela perda progressiva de secreção de insulina, ou resistência à mesma, associado ao quadro de sobrepeso ou obesidade do paciente (90-95\% dos diabéticos). O DM gestacional é geralmente diagnosticada no segundo ou terceiro trimestre de gravidez, sendo qualquer intolerância à glicose, devido às mudanças hormonais (SBD, 2009; WHO, 1999; ADA, 2016, WHO, 2016).

Para o diagnóstico de DM, temos: condições de poliúria, polifagia, polidipsia e perda de peso associados à glicemia sanguínea casual acima de 200 miligramas (mg) de glicose por decilitro ( $\mathrm{dl}$ ) de sangue; relacionado à glicemia plasmática de jejum (GPJ) (oito horas sem ingestão de alimentos) que deve ser igual ou superior ao valor de $126 \mathrm{mg} / \mathrm{dl}$; baseado no teste oral de tolerância à glicose (TOTG), isto é, a avaliação glicêmica de duas horas pós-sobrecarga de $75 \mathrm{~g}$ de glicose com valores acima de 200mg/dl (SBD, 2009). O teste A1C ou teste de hemoglobina glicada (HbA1c) com limiar abaixo ou igual a $6,5 \%$ foi recentemente foi recomendado (resume o valor glicêmico do paciente no período anterior de 60 a 90 dias) (ADA, 2016, WHO, 2016).

O indivíduo portador diabetes está sujeito a complicações crônicas de caráter micro e macrovascular. As microangiopatias estão associadas com complicações clínicas clássicas como retinopatia, nefropatia e neuropatia, enquanto as macroangiopatias são complicações relacionadas com doença isquêmica do coração, infarto e doenças vasculares periféricas (WHO 1999; WHO, 2016).

Existem evidências de que pacientes diabéticos apresentam anormalidades de desenvolvimento dos maxilares e mandíbula. Estudos clínicos e experimentais 
(El-Bialy, Aboul-Azm, El-Sakhawy, 2000; Giglio e Lama, 2001; Abbassy, Watari, Soma, 2008) relataram uma diminuição nos parâmetros cefalométricos e atraso no desenvolvimento esquelético em pacientes com DM1, fatores que predispõe às maloclusões dentárias.

O DM também é responsável por aumentar a suscetibilidade à doença periodontal (IDF, 2009; Um et al., 2010; Sanz et al., 2018), aumentar o risco de fratura em ossos (Starup-linde et al., 2016; Palermo et al., 2017), alterar e comprometer o processo de reparo ósseo e de tecido mole (Mishima et al., 2002; Lu et al., 2003; Thrailkill et al., 2005; Villarino, Lewicki, Ubios, 2011). Como o diabetes afeta o metabolismo ósseo, pode afetar não apenas a movimentação dentaria, mas também a reabsorção radicular (Arita et al., 2016). Segundo Kanazawa e Sugimoto (2018), a fragilidade óssea induzida pelo DM foi recentemente reconhecida como uma complicação diabética e como o risco de fratura é independente da redução da densidade mineral óssea, a deterioração da qualidade óssea pode ser a principal causa da fragilidade óssea.

A sustentação dos dentes nos óssos basais ocorre através do periodonto, composto por quatro tecidos conjuntivos, subdividido em periodonto de sustentação (cemento, ligamento periodontal e osso alveolar) e o peridonto de proteção (gengiva) (Katchburian, Arana, 1999; Tem, Cate 2001). O ligamento periodontal (LP) apresenta elevado metabolismo celular e sofre grande remodelação. É um tecido conjuntivo celular, inervado e vascularizado, que possui função sensorial, de suporte e fixação do dente no alvéolo, nutrição e homeostasia. Através de seus espessos feixes de fibras colágenas, conecta o cemento (que recobre a raiz do dente) à superfície cortical do osso alveolar, ambos tecidos mineralizados. Dentre as células que o compõe, temos cementoblastos, osteoclastos, osteoblastos, células de defesa, células progenitoras (Tem Cate, 2013).

A movimentação dentária é a base do tratamento ortodôntico e está fundamentada no princípio biológico de que uma pressão prolongada aplicada nos dentes, resulta na remodelação das estruturas periodontais, como osso alveolar e ligamento periodontal (Kirkanydes et al., 2000). A transmissão da força gera uma resposta biológica descrita por Garlet et al. (2007) como uma inflamação aguda e não patológica. Segundo Hughes (2000), este evento inflamatório desencadeia mudanças vasculares, síntese e liberação de prostaglandinas, citocinas e fatores de 
crescimento, os quais induzem à diferenciação de células mesenquimais indiferenciadas em osteoblastos e osteoclastos, responsáveis pela deposição e reabsoção do osso alveolar, respectivamente. Nas áreas de compressão, ocorre a reabsorção da matriz óssea e remodelação do colágeno extracelular, e nas áreas de estiramento do ligamento periodontal, ocorre a deposição de osso alveolar e de colágeno (Nakagawa et al.,1994; Krishnan, Davidovitch, 2006; Masella, Meister, 2006).

Qualquer força exercida sobre os dentes é imediatamente transmitida ao ligamento periodontal e, através de seus feixes de fibras, ao osso de suporte, mas para a força ser eficiente e produzir movimentação dentária, é necessário que cause certo grau de estresse nos tecidos periodontais, por hipóxia ou por compressão (Consolaro, 2005), formando áreas de pressão e tração, associadas à absorção e aposição de osso alveolar, respectivamente, (Gianelly, 1969; Gianelly e Goldman 1951; Macapanpan, Weinmann, Brodie 1954). Na área de tração, na fase inicial pode-se observar distensão periodontal, estiramento de fibras periodontais e aumento do espaço periodontal, enquanto que na área de pressão, ocorre compressão tecidual e deflexão óssea (Consolaro, 2005).

Estudos observaram que tanto a movimentação dentária ortodôntica decorrente da ortodontia, foram significantemente menores em ratos diabéticos do que em ratos normais (Arita et al., 2016). Maia et al. (2014), ao analisarem as alterações histológicas do ligamento periodontal e osso alveolar após a movimentação dentária em ratos com diabetes, observaram alterações metabólicas e efeitos indesejáveis na remodelação óssea pós forças leves. Na literatura observase um relato de caso de DM associado ao tratamento de expansão rápida da maxila (ERM), no qual o paciente apresentou uma úlcera necrótica no palato após a ERM, e a reversão dos sinais e sintomas após identificação e tratamento do DM1 (Maia et al., 2011). Já Villarino, Lewicki e Ubius (2011) analisaram histologicamente a resposta óssea de ratos diabéticos não tratados e insulino-tratados após a aplicação de forças ortodônticas e observaram que a resposta óssea a forças ortodônticas em animais diabéticos insulino-tratados, não diferiu significantemente à observada em animais saudáveis, mesmo que na utilização de forças pesadas.

Arnez (2014) observou que ratos induzidos ao diabetes mellitus e submetidos à ERM, tiveram alteração da expressão gênica e proteica de diferentes 
biomarcadores do processo de remodelação óssea, resultando em um comprometimento do reparo ósseo na região da sutura palatina mediana.

A remodelação óssea é orquestrada por células da linhagem osteoblástica e envolve uma rede complexa de interações célula-célula, célula-matriz e de múltiplas vias de sinalização celular, juntamente com a participação de hormônios sistêmicos, fatores de crescimento, produção de citocinas locais, que atuam de maneira autócrina e parácrina (Meikle, 2006). Estas moléculas podem estimular muitas respostas celulares através de diversos tipos de células no tecido ósseo, desta forma, fornecendo um microambiente favorável para deposição e reabsorção tecidual (Davidovitch et al.,1988).

Os eventos celulares e moleculares que acontecem durante a osteogênese tem sido amplamente investigados com a finalidade de compreender o processo de remodelação óssea. $O$ processo de reabsorção óssea necessita da ação dos clastos, osteoblastos e macrófagos, que juntos formam a unidade osteoremodeladora, cujos gerentes são os osteoblastos, presentes nas corticais e trabéculas ósseas e que recebem informação através de mediadores químicos e transmitem as informações para as demais células (Consolaro, 2005).

Os osteoclastos são células gigantes multinucleadas e responsáveis pela reabsorção óssea, móveis, fagocitárias, e encontradas ao longo da superfície endóstea cortical e nas lacunas de Howship (áreas de reabsorção). Originam-se das células do sistema monócito/macrófago (sistema hematopoiético). A osteoclastogênese começa com o estímulo das células hematopoiéticas, que então se diferenciam em pré-osteoclastos. Os pré-osteoclastos fundem-se com outras células semelhantes para formar um osteoclasto imaturo multinuclear (Garant, 2003; Lerner, 2000; Robey et al. 1993). Em cortes histológicos, os osteoclastos são facilmente identificados por sua aparência multinuclear e coloração positiva para fosfatase ácida tártaro-resistente (TRAP). Embora o TRAP não seja um marcador específico para a identificação de osteoclastos (é expressado em macrófagos alveolares humanos, osteoclastos, baço e fígado), ele é um marcador útil para identificar osteoclastos em lâminas histológicas, pois células de linhagem osteogênica não expressam TRAP (Fukushima, Bekker, Gay 1991; Minkin, 1982). A tríade RANK, RANK-L e OPG tem sido estudada por sua importante participação na remodelação óssea (Arnez et al., 2017). O desequilíbrio da tríade RANK/RANKL/OPG pode ser observado na doença periodontal, osteoporose e artrite reumatóide (Boyle et al., 2003, Amorim et al., 2008). O RANKL (RANK ligante) 
é uma molécula importante para a diferenciação das células hematopoiéticas progenitoras em osteoclastos maduros e exerce seus efeitos por meio de sua ligação ao receptor RANK (receptor ativador do fator nuclear kappa B). Por outro lado, a proteína circulante osteoprotegerina (OPG) bloqueia a osteoclastogênese (Boyle et al 2003), pois se a OPG se liga ao RANKL, este não pode se ligar ao RANK, impossibilitando que as células osteoprogenitoras se diferenciem em osteoclastos.

Apesar de vários estudos mostrarem que em pacientes e animais diabéticos há um processo de reparo ósseo comprometido, quando do emprego de estresse ortodôntico, a maioria (Li et al., 2010; Braga et al., 2011; Villarino, Lewicki e Ubios, 2011; Zhang et al., 2011; Maya et al., 2014; Plut et al., 2015; Arita et al., 2016; Gomes et al., 2017) observou resultados associados aos movimentos dentários em diabéticos, mas não as alterações no periodonto de sustentação, durante movimentos ortodônticos de grande magnitude, como a expansão rápida da maxila.

Durante a última década, a prevalência de diabetes aumentou mais rapidamente em países de baixa e média renda do que nos países de alta renda (WHO, 2016). Visto que o diabetes mellitus é um problema de saúde pública de grande relevância, sendo que um em cada 11 adultos no mundo tem diabetes, destes, 1 em cada 2 adultos não foi diagnosticado, mais de 1 milhão de crianças e adolescentes tem diabetes tipo 1 e no Brasil estima-se 30900 crianças com DM tipo 1 (IDF, 2017),considerando que essa doença sistêmica interfere no desenvolvimento esquelético e no processo de formação e remodelação óssea, e o crescente acesso ao tratamento ortodôntico de maloclusões inclusive submetidas a forças de grande magnitude, acredita-se ser de fundamental importância avaliar a expressão de proteínas ósseas envolvidas na sinalização osteoblasto-osteoclasto no periodonto de sustentação após a expansão rápida da maxila em ratos diabéticos-induzidos, insulino-tratados e não tratados, em avaliações de diferentes períodos.

A análise da qualidade óssea através do ponto de vista histológico e protêico, tem grande potencial para contribuir para um melhor entendimento da formação óssea em diabéticos submetidos à forças ortopédicas e isso pode contribuir para a investigação da fisiopatologia óssea no alvéolo dentário. 
2. Proposição 



\section{PROPOSIÇÃO}

\subsection{Objetivo geral}

O objetivo do presente estudo foi avaliar in vivo a influência da aplicação de forças ortopédicas obtidas através da expansão rápida da maxila (ERM), em ratos com diabetes mellitus tipo I, sobre o processo de remodelação do periodonto de sustentação, por meio de análise miscroscópica e imunoistoquímica.

\subsection{Objetivos específicos}

1. Avaliar através da descrição histomorfológica qualitativa o efeito da ERM em ratos com diabetes mellitus tipo I, insulino-tratados ou não, na remodelação do periodonto de sustentação, em diferentes períodos, comparativamente a ratos saudáveis.

2. Avaliar quantitativamente a imunomarcação das proteínas TRAP, RANKL e OPG, em ratos com diabetes mellitus tipo I, insulino-tratados ou não, submetidos ou não à ERM, em diferentes períodos, comparativamente a ratos saudáveis. 

3. Xateriale Xétodos 



\section{MATERIAL E MÉTODOS}

\subsection{Amostragem}

Foram usados 90 ratos da raça Wistar (Rattus norvegicus albinus), machos, com 90 dias de vida (adultos), pesando em média $300 \mathrm{~g}$. Os animais apresentavamse saudáveis e em condições de serem submetidos aos procedimentos operatórios. Animais machos foram utilizados para eliminar qualquer variabilidade hormonal devido ao ciclo reprodutivo feminino. Neste projeto consideramos para o cálculo amostral a variável primária diabetes para testar a hipótese de que o diabetes apresenta efeito na remodelação óssea pós-disjunção. O poder do teste foi de $80 \%$, com nível de significância de 5\%, determinando um número amostral de 5 animais por grupo. Ou seja, o " $n$ " amostral foi calculado com base no alfa igual a $5 \%(p=0.05)$ e o beta de $80 \%$. Os ratos foram fornecidos pelo Biotério Central da Universidade de São Paulo, campus de Ribeirão Preto. Este projeto teve a aprovação da Comissão de Ética no Uso de Animais (CEUA- USP), sob protocolo 10.1.1026.53.6 (anexo). Durante o período experimental os animais foram alimentados com dieta padrão constituída por ração convencional (Labina - Purina) em grãos para os ratos sem a instalação de aparelho ortodôntico e moída para os ratos submetidos ao uso de aparelho ortodôntico, a fim de se evitar eventuais danos ao aparelho ortodôntico durante a mastigação, água ad libitum e mantidos em ambiente aclimatizado por todo o período experimental.

Durante a fase experimental, as gaiolas foram identificadas com etiquetas, nas quais constavam o número de animais e o grupo ao qual pertenciam. Além disso, cada animal recebeu a marcação de seu número na cauda com caneta de retroprojetor (Faber-Castell), o que o diferenciou dentro de seu próprio grupo e dos animais de outros grupos, facilitando a sua identificação. 


\subsection{Delineamento Experimental}

Para cada período experimental após a expansão rápida da maxila $\left(3^{\circ}, 7^{\circ}\right.$ ou $10^{\circ}$ dia) foram utilizados cinco animais $(n=5)$, distribuídos aleatoriamente de acordo com a Tabela 1.

Tabela 1. Grupos experimentais, tempos, número de animais e procedimentos propostos.

\begin{tabular}{|c|c|c|c|c|}
\hline \multirow{3}{*}{ Grupos } & \multicolumn{3}{|c|}{ Imunohistoquímica e Histológico } & \multirow{3}{*}{ Descrição do Grupo Experimental } \\
\hline & \multicolumn{3}{|c|}{ Tempo experimental } & \\
\hline & 3 dias & 7 dias & 10 dias & \\
\hline C & 5 ratos & 5 ratos & 5 ratos & Veículo \\
\hline ERM & 5 ratos & 5 ratos & 5 ratos & Veículo + Expansão Rápida da Maxila (ERM) \\
\hline DM & 5 ratos & 5 ratos & 5 ratos & Induzidos ao diabetes \\
\hline DM+ERM & 5 ratos & 5 ratos & 5 ratos & Induzidos ao diabetes + ERM \\
\hline DM+INS & 5 ratos & 5 ratos & 5 ratos & Induzidos ao diabetes + insulina \\
\hline DM+INS+ERM & 5 ratos & 5 ratos & 5 ratos & Induzidos ao diabetes + insulina + ERM \\
\hline Total & & 90 ratos & & $\begin{array}{l}\text { Total de animais distribuídos nos } \\
\text { diferentes grupos experimentais }\end{array}$ \\
\hline
\end{tabular}

No primeiro dia de experimento (dia zero), todos os animais foram submetidos à análise de normoglicemia de jejum. Após esta análise, todos os grupos receberam uma injeção intraperitoneal, ou contendo veículo (para os animais controle, não induzidos ao diabetes), ou contendo o medicamento estreptozotocina (para os animais induzidos ao diabetes). No dia seguinte, os valores de glicemia foram reavaliados (animais normoglicêmicos ou hiperglicêmicos, de acordo com seu grupo), e novamente avaliados no vigésimo oitavo dia. No 28으 dia após a avaliação da glicemia, os animais foram enfim anestesiados para a realização da expansão rápida da maxila (de acordo com seu grupo). A partir deste momento, os animais foram submetidos à eutanásia no período de 3,7 ou 10 dias. No $29^{\circ}$ dia, iniciou 0 tratamento dos animais dos grupos tratados com insulina. Os animais foram monitorados quanto ao controle de glicemia, consumo hídrico e peso corporal. 
Figura 1- Esquema ilustrando o delineamento experimental do estudo e os procedimentos experimentais executados em seus respectivos intervalos de tempo

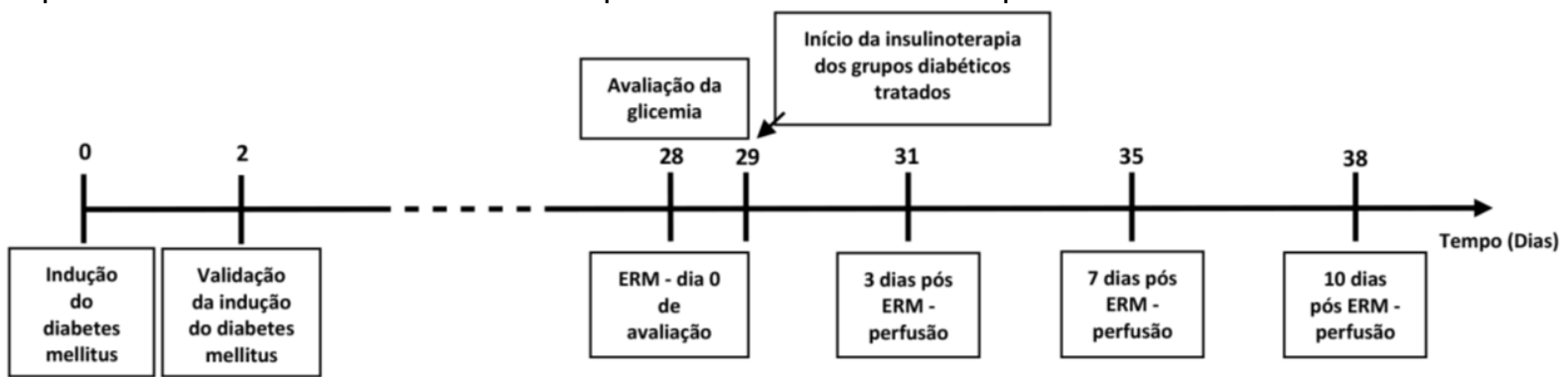

\subsection{Manipulação dos animais}

\subsubsection{Anestesia dos animais}

Os procedimentos nos animais foram realizados sob anestesia e sedação por via intramuscular utilizando solução de Cloridrato de Ketamina (Vetaset ${ }^{\circledR}$ - Fort Dodge Animal Health, lowa, USA) na dosagem de 0,07 $\mathrm{ml}$ para cada $100 \mathrm{~g}$ de peso corporal para a indução anestésica) associado com a solução de Cloridrato de Xilazina (Coopazine® - Coopers Brasil Ltda, Cotia, SP, Brasil) na dosagem de 0,03 $\mathrm{ml}$ para cada $100 \mathrm{~g}$ de peso corporal, promovendo o relaxamento muscular.

A avaliação do valor glicêmico foi realizada com o animal acordado e sob contenção manual, para não haver alteração deste valor.

\subsubsection{Indução e Controle do Diabetes Mellitus}

Inicialmente todos os animais foram submetidos à coleta de sangue, via veia caudal, para a realização do exame da taxa glicêmica. Após o período de 24 horas de jejum, exceto água ad libitum, para a realização da taxa glicêmica, os animais dos grupos DM, DM+INS, DM+ERM e DM+INS+ERM foram induzidos ao diabetes mellitus, no dia zero do experimento, através da administração de dose única de estreptozotocina (STZ) (Sigma Chemical Co, St. Louis, MO) na concentração de $50 \mathrm{mg} / \mathrm{kg}$ por peso e diluído no veículo tampão citrato (Sigma Chemical, St. Louis, MO) a 0,09M e pH = 4,5, por via intraperitoneal (Nascimento-Saba et al., 1997; Li et al., 2010; Villarino, Lewicki, Ubios, 2011), com seringa de $1 \mathrm{ml}$ e agulha acoplada de 12,7mm (BD Ultra-Fine® Original). A substância estreptozotocina é um antibiótico de ocorrência natural, derivado do Streptomyces acromogenes, que apresenta uma ação diabetogênica em animais, uma vez que destrói as células $\beta$ das ilhotas do pâncreas. Esta toxina quando injetada em ratos produz uma prejudicada resposta 
insulínica às injeções de glicose, assim como baixa tolerância a glicose e um elevado nível glicêmico basal (Blondel, Bailbe, Portha, 1989). Os animais do Grupo C e ERM ( $n=30)$ receberam também por via intraperitonial o veículo tampão citrato $(1 \mathrm{ml})$, com o intuito de promover nestes animais o mesmo grau de estresse dos demais grupos. A alimentação foi restituída aos animais 12 horas após a administração da STZ e da solução tampão.

No primeiro e no segundo dia, após dez horas de jejum diurno, todos os animais da amostra foram submetidos ao exame sanguíneo para verificação da concentração de glicose capilar (taxa glicêmica).

A avaliação do valor glicêmico foi realizado com o animal acordado e sob contenção manual. A verificação da hiperglicemia foi feita na cauda do rato. A veia caudal do rato foi dilatada com o auxílio de água à temperatura de $30^{\circ} \mathrm{C}$. No terço médio e inferior da cauda do rato foi feita uma punção venosa, a fim de coletar o sangue para verificação da glicemia. $O$ sangue foi gotejado em fita reagente própria para o aparelho One Touch Ultra, (Johnson \& Johnson Medical S.A., China), que realizou imediatamente a leitura da glicemia. A concentração de glicose padronizada foi menor que $126 \mathrm{mg} / \mathrm{dl}$ para os animais dos grupos C e ERM, e maior que $300 \mathrm{mg} / \mathrm{dl}$ para os grupos STZ-injetados (DM, DM+INS, DM+ERM, DM+INS+ERM).

Exames semelhantes foram realizados no vigésimo oitavo dia de experimento, a fim de confirmar os ratos hiperglicêmicos (níveis glicêmicos maiores que $300 \mathrm{mg} / \mathrm{dl}$ ) antes da realização da expansão rápida da maxila.

No dia 29, foi instituído o tratamento com insulina NPH humana (Novolin N Penfill, Bagsvaerd, Dinamarca) montada em caneta (NovoPen® 3 Demi, Novo Nordisk $\Theta$, Tiajin, China) e acoplada com agulhas apropriadas de $4 \mathrm{~mm}$ (BD UltrafineTM, Dublin, Irlanda) nos animais dos grupos DM+INS e DM+INS+ERM. A administração de insulina foi feita por via subcutânea. O protocolo de insulinoterapia utilizado foi de 2 UI pela manhã (8h) e 4 UI a tarde (17h) até a data da eutanásia (Sabino-Silva et al., 2009; Okamoto et al., 2011).

\subsubsection{Procedimento de Expansão Rápida da Maxila e instalação de dispositivo ortodôntico}

No vigésimo oitavo dia após a indução do diabetes mellitus, realizou-se os testes glicêmicos e depois os animais dos grupos ERM, DM+ERM e DM+INS+ERM foram anestesiados e posicionados em mesa operatória apropriada. A expansão 
rápida da maxila foi realizada por um operador treinado, com o auxílio de uma espátula 7 (S.S. White, Duflex, RJ, Brasil), posicionada no terço cervical dos incisivos, e com movimentos rotacionais, obteve a separação da sutura palatina mediana e realizou a instalação do dispositivo ortodôntico para mantê-la aberta.

Os dispositivos ortodônticos foram confeccionados com auxílio de alicate n¹39 (3M Unitek) para manter a disjunção maxilar, e eram constituídos de uma mola passiva (1,5 mm largura de fio de aço inoxidável de 0,5mm de diâmetro) (Morelli, SP, Brasil) posicionada entre os incisivos superiores (Figura 2). A espessura da mola de aço inoxidável foi determinada com base em resultados de um estudo preliminar (Sawada e Shimizu, 1996) que indicou que 1,5mm de disjunção entre os incisivos induz a taxa máxima de disjunção na sutura palatina mediana sem diminuição contínua do peso corpóreo do animal.

Figura 2- A- Fotografia do dispositivo ortodôntico utilizado, B- Animal posicionado na mesa operatória, C- espátula 7 utilizada na ERM, posicionada entre incisivos, D- dispositivo ortodôntico em posição, E- resina recobrindo o dispositivo ortodôntico
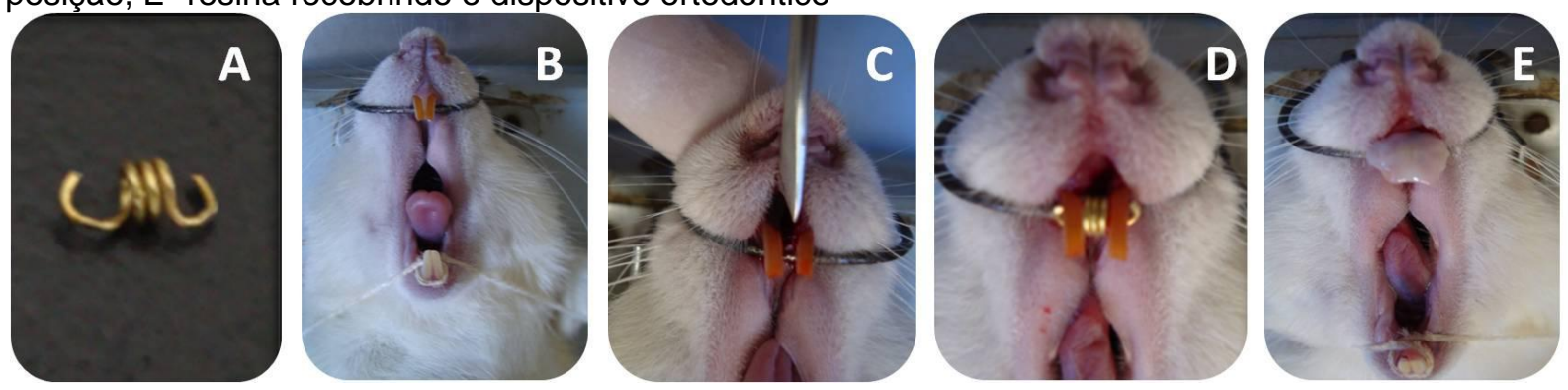

$\mathrm{Na}$ montagem do dispositivo para disjunção foram utilizados alicates $n^{0} 139$ (3M Unitek, SP, Brasil), alicate para corte de fio espesso (Dentaurum, Springen, Alemanha), espelho bucal (S.S. White, Duflex, RJ, Brasil), sonda exploradora $n^{\circ} 5$ (S.S. White, Duflex, RJ, Brasil) e calcador de anéis (S.S. White, Duflex, RJ, Brasil). Todos os dispositivos ortodônticos foram confeccionados e instalados pelo mesmo operador e assistente, seguindo sempre o mesmo protocolo.

Previamente a montagem do dispositivo para a disjunção maxilar, a superfície dos incisivos foi preparada para aumentar a retenção e estabilização do mesmo. Foi utilizada uma broca esférica diamantada $n^{0} 1011$ (K.G. Sorensen, SP, Brasil) em motor de alta rotação (Dabi-Atlante, SP, Brasil) para confeccionar sulcos rasos, apenas no esmalte, no terço gengival das faces vestibular e distal dos incisivos superiores. Em seguida foi realizada profilaxia dos incisivos com pasta de pedra-pomes misturada com água aplicada em taça de borracha (Viking) em contra- 
ângulo adaptado ao micromotor (Dabi- Atlante, SP, Brasil) por 15 segundos. Realizou-se a lavagem com spray (água-ar) e a secagem com ar proveniente da seringa tríplice. O condicionamento do esmalte nos incisivos foi realizado utilizando ácido ortofosfórico à 37\% em forma de gel (3M, SP, Brasil), durante 60 segundos, conforme recomendações do fabricante. Na sequência foi feita novamente a lavagem e secagem das superfícies dentárias, por 15 segundos, com o auxílio da seringa tríplice. O agente de união Primer \& Bond 2.0 (Dentsply, SP, Brasil) foi aplicado sobre a superfície condicionada do esmalte e fotopolimerizado com luz halógena por 20 segundos (comprimento de onda de 470nm) com auxílio do aparelho Heliomat II (Vigodent, RJ, Brasil).

A resina fotopolimerizável Transbond ${ }^{\mathrm{TM}}$ (3M Unitek, SP, Brasil) foi adaptada sobre o segmento de fio nas faces vestibular e distal recobrindo-o e, em seguida foi realizada a polimerização durante 30 segundos, dirigida em orientação oclusal, vestibular, mesial e distal de cada incisivo. Para compensar o desgaste decorrente do contínuo hábito roedor dos animais, várias camadas de resina foram fotopolimerizadas sobre o grampo. Após a colocação do aparelho, ele não recebeu ativação adicional durante o experimento.

Todos os procedimentos operatórios foram realizados na sala de Cirurgia Experimental do Bioterio I da Faculdade de Odontologia de Ribeirão Preto da Universidade de São Paulo (FORP-USP), sob condições de assepsia higiene adequada e pelos mesmos operadores.

\subsubsection{Avaliações Clínicas}

O correto posicionamento do dispositivo ortodôntico foi conferido diariamente, quanto à posição, à estabilidade e à necessidade de correções na eventualidade de estar causando injúrias à mucosa oral do animal.

Foi realizada a mensuração do consumo hídrico $(\mathrm{ml})$ dos animais através de garrafas de vidro graduadas, a avaliação de peso (g) em balança digital (Filizola, SP, Brasil) e mensuração da glicemia dos animais (mg/dl). Tais avaliações foram feitas para acompanhar o polidipsia, alteração de peso e nível glicêmico dos animais e foram realizados diariamente na primeira semana de experimento e depois semanalmente, até o vigésimo oitavo dia, quando foi confirmada a glicemia. A partir de então, a avaliação de peso e consumo hídrico continuaram diariamente, até o dia da eutanásia. 


\subsubsection{Eutanásia dos animais e coleta dos Espécimes}

Os procedimentos operatórios foram realizados na sala de cirurgia experimental do Biotério I da FORP-USP, sob condições de limpeza, anti-sepsia e desinfecção, com instrumentos esterilizados em autoclave. Decorrido os períodos experimentais de 3,7 ou 10 dias, foi administrado a todos os animais uma sobredose de Ketamina $(80 \mathrm{mg} / \mathrm{Kg})$ e Xilazina $(10 \mathrm{mg} / \mathrm{Kg})$, via intramuscular e, em seguida, os animais foram perfundidos por via intracardíaca utilizando bomba perfusora Masterflex LS (Cole-Parmer Instrumet Company, Vermon Hills, IL, USA). A perfusão foi realizada com 200ml de tampão fosfato salino a 10\%, pH 7,4 (PBS) a $38^{\circ} \mathrm{C}$ seguida de solução fixadora $(400 \mathrm{ml})$ de paraformaldeído (Sigma ChemicalCo., St. Louis, MO, USA) a $4 \%$ em tampão fosfato de sódio (Sigma ChemicalCo.,St. Louis, MO, USA) a $0,1 \mathrm{M}, \mathrm{pH} 7,4$ a $4^{\circ} \mathrm{C}$. A maxila, preservando a sutura palatina mediana e os incisivos superiores, foi removida, dissecada e, imediatamente conservada e fixada em formol tamponado a $10 \%$ por 48 horas em frascos individuais de cada grupo experimental, para posterior processamento histológico.

\subsection{Preparo das peças para exame histológico e imunohistoquímico}

O preparo das peças para a microscopia ótica foi realizado no Departamento de Morfologia da Faculdade de Odontologia de Ribeirão Preto (FORP-USP). Após a eutanásia, as peças foram fixadas em formol tamponado a 10\% por 48 horas, em frascos individuais. Na sequência, os espécimes foram lavados em água corrente por 24 horas e colocados em solução desmineralizadora à base de EDTA a 4,13\% (etileno-diaminotetra-acético, Merck®, Darmstadt, Alemanha), tamponado em pH neutro $(7,0-7,4)$, por um período de aproximadamente 3 meses. Esta solução foi renovada a cada 72 horas, com 0 intuito de preservar a matriz orgânica durante 0 processo de descalcificação. A confirmação da descalcificação das secções anatômicas foi realizada através de radiografias obtidas das peças anatômicas, durante o período de descalcificação, a fim de avaliar o grau de calcificação das peças.

Depois de submetidos à desmineralização, todos os espécimes foram imersos em sulfato de sódio a $5 \%$ por 24 horas à temperatura ambiente, com a finalidade de neutralizar a ação da solução descalcificadora. Os espécimes foram lavados em água corrente por 24h. Posteriormente, foi realizada desidratação em concentrações crescentes de álcoois, 70\%, 80\%, 90\% e 100\% (Reagen, PR, Brasil), 
sucessivamente, por 60 minutos à temperatura ambiente, a fim de evitar trocas osmóticas bruscas, o que poderia causar alterações nas estruturas teciduais. Concluída a desidratação, as peças foram diafanizadas em três banhos de xilol (Merck, RJ, Brasil). O xilol é miscível em álcool e em a parafina, isto é, remove todo o álcool das peças anatômicas e fornece ao tecido condições de ser impregnado pela parafina. O tempo de imersão em cada solução de xilol I, II e III dependeu da evolução da diafanização. De modo geral, as peças ficaram em torno de 40 minutos em cada solução.

Após o xilol substituir todo o álcool nas peças, estas foram submetidas à parafinização lenta, promovida por seguidos banhos de xilol-parafina, nas proporções de 2:1, 2:2, e parafina pura (Reagen, PR, Brasil), sendo que as peças ficaram imersas uma hora em cada banho. Durante este procedimento as peças foram mantidas em estufa de temperatura constante regulada para $58^{\circ} \mathrm{C}$, até que 0 xilol fosse completamente substituído pela parafina fundida. Assim que a infiltração se completou, as peças foram posicionadas no centro de formas de alumínio com dimensões aproximadas de $30 \mathrm{~mm}$ de extensão por $15 \mathrm{~mm}$ de largura e profundidade que foram preenchidas com parafina fundida de baixa temperatura de fusão (56$58^{\circ} \mathrm{C}$, Reagen). Antes da solidificação, cada peça foi posicionada no centro da forma de alumínio com parafina, com o auxílio de uma pinça clínica (Duflex) aquecida, de tal modo que a superfície oclusal dos molares ficasse paralela ao sentido dos cortes desejados. Os blocos de parafina solidificados foram identificados e colocados em água gelada e, em seguida, no refrigerador, para evitar sua cristalização. Em seguida esses blocos foram removidos das formas de alumínio, reduzidos com navalha apropriada, até permanecer $5 \mathrm{~mm}$ de parafina de cada lado da peça de interesse e alcançar paralelismo ideal para serem seccionados no micrótomo rotativo de precisão (Spencer, modelo 820).

Secções longitudinais semi-seriadas foram obtidas em micrótomo com $5 \mu \mathrm{m}$ de espessura. As fitas foram levadas ao cristalizador (Robertshaw, IL, EUA), onde foram distendidas e montadas em lâminas silanizadas para microscopia (Objektträger - Knittel Gläser, Bielefeld, Alemanha). Posteriormente, estas lâminas foram mantidas em estufa, em posição vertical, por 24 horas, a $40^{\circ} \mathrm{C}$, para favorecer a remoção da umidade e aderência do material à lâmina. 
As lâminas foram divididas em dois grupos, sendo que o primeiro grupo foi corado pela técnica de Hematoxilina e Eosina (H/E) e Tricrômico de Masson (TM) e o segundo grupo para análise imunohistoquímica.

\subsubsection{Coloração dos cortes para microscópio de luz}

Para que o corte pudesse ser submetido à coloração, foi realizada a desparafinização das lâminas. Para isso procedeu-se primeiro à eliminação da parafina dos cortes pelo xilol, mergulhando as lâminas em soluções de xilol I, II e III, com duração de 10 minutos em cada solução. Assim que foi constatada a eliminação da parafina dos cortes, foi iniciado o processo de hidratação, quando o xilol foi removido com banhos de álcool absoluto I, II e III, (Reagen) e, em seguida álcool 95\%, por 3 minutos em cada solução, até chegar à água destilada. Esse procedimento tem a finalidade de evitar fenômenos osmóticos bruscos, os quais produzem retrações e deslocamento do material da lâmina. Os cortes histológicos foram montados em série e corados com hematoxilina e eosina $(\mathrm{H} / \mathrm{E})$ e tricrômico de Masson (TM).

Para a coloração por $\mathrm{H} / \mathrm{E}$, os cortes hidratados foram submetidos à coloração pôr hematoxilina (Merck) por 3 minutos. Em seguida, realizou-se a lavagem das lâminas em água corrente até assumirem tom azulado, sendo então, mergulhadas rapidamente em solução de álcool acetificado (solução de ácido acético glacial diluído em álcool 95\%). Nova lavagem foi realizada em água corrente por 2 a 5 minutos e álcool a 95\%. A eosina foi utilizada (Merck) pôr 2,5 minutos, dando aos tecidos uma cor rosada. A seguir foi realizada nova desidratação através de três banhos de álcool absoluto I, II e III por 3 minutos cada, e três banhos de xilol (Merk) I, II e III também por 3 minutos cada. Finalmente, as lâminas foram cobertas com lamínulas montadas com Entellan (Merck).

Para a coloração por TM, os cortes hidratados foram submetidos à coloração por Alumen de ferro a $5 \%$, dentro da estufa $\left(38^{\circ} \mathrm{C}\right.$ a $\left.40^{\circ} \mathrm{C}\right)$ por $17 \mathrm{~min}$. Em seguida, realizou-se a lavagem das lâminas em água corrente, seguida por água destilada. Os cortes foram então submetidos à coloração pôr Hematoxilina de Regaud dentro da estufa $\left(38^{\circ} \mathrm{C}\right.$ a $\left.40^{\circ} \mathrm{C}\right)$ por 15 minutos. Em seguida realizou-se a lavagem em água destilada sendo então, mergulhadas rapidamente em solução de álcool 95\%, e em seguida mergulhadas também rapidamente em solução de álcool pícrico por 30 segundos. As lâminas foram então, submetidas à nova lavagem em água destilada e 
a Mistura de Ponceau por 12 minutos. Os cortes foram mergulhados rapidamente em água acetificada a 1\% (solução de ácido acético glacial diluído em água destilada) e submetidos à solução de Ácido fosfomolibídico a 1\% por 15 minutos. Nova lavagem em água destilada foi realizada e os cortes foram submetidos à solução de Azul de anilina por 3 minutos, seguida por lavagem rápida em água acetificada à $1 \%$, submetidas à solução de Ácido fosfomolibídico por 2 minutos e nova lavagem rápida em água acetificada a $1 \%$. A seguir foi realizada nova desidratação através de três banhos de álcool absoluto I, II e III por 3 minutos em cada e três banhos de xilol I, II e III também por 3 minutos cada. Finalmente, as lâminas foram cobertas com lamínulas montadas com Entellan (Merck).

Terminada a montagem e secagem das lâminas, estas com os respectivos cortes corados foram rotuladas, onde os cortes foram identificados, e, posteriormente, foram acondicionadas em caixas apropriadas e armazenadas em ambiente seco e fresco, estando, finalmente, prontos para exame histológico ao microscópio de luz.

\subsubsection{Coloração dos cortes para imunoistoquímica}

As lâminas foram preparadas para o processamento imunoistoquímico previamente à adição dos anticorpos. Como anticorpos primários foram utilizados a Osteoprotegerina - OPG (Goat anti-OPG polyclonal antibody - Santa Cruz Biotechnology® - SC 21038, Califórnia, USA), o TRAP (Goat anti-TRAP polyclonal antibody - Santa Cruz Biotechnology ${ }^{\circledR}$ - SC 30832, Califórnia, USA) e o RANKL (Goat anti-RANKL polyclonal antibody - Santa Cruz Biotechnology ${ }^{\circledR}$ - SC 7627, Califórnia, USA). O anticorpo secundário utilizado foi o biotinilado anti-cabras, produzido em coelhos (Pierce Biotechnology ${ }^{\circledR}$, Illinois, USA).

Para os cortes destinados aos ensaios de imunoistoquímica para as proteínas TRAP, RANKL e OPG, as lâminas foram desparafinizadas, hidratadas em série descrecente de álcoois e mantidas em solução salina fosfatada tamponada (PBS). Em seguida a peroxidase endógena foi bloqueada com peróxido de hidrogênio a 1,5\% diluído em metanol por 30 minutos. As lâminas foram lavadas em PBS por 5 minutos (2X) e submetidas à recuperação dos epítopos antigênicos utilizando solução tampão de citrato de sódio $\left(\mathrm{pH} \mathrm{6,0)}\right.$ aquecido a $93^{\circ} \mathrm{C}$ por 15 minutos. Depois foram lavadas em PBS por 5 minutos $(2 x)$ e os sítios de ligação não-específica foram bloqueados com albumina de soro bovino a $1 \%$ por 30 
minutos. Os tecidos foram incubados com os anticorpos primários (Santa Cruz Biotechnology Inc., Santa Clara, CA, EUA) para cada proteína de interesse. Estes anticorpos foram previamente titulados com o objetivo de determinar as concentrações e tempo de incubação adequados para cada anticorpo. Em seguida as lâminas foram lavadas e incubadas com anticorpos secundários biotinilados por 1 hora, lavadas em PBS, e incubadas com estraptavidina conjugada à horseradish peroxidase (HRP) por 20 minutos. O sinal da reação imunoistoquímica foi amplificado com o sistema avidina-biotina (Kit DAKO, Glostrup, Dinamarca) e a reação foi revelada utilizando a diaminobenzidina (DAB, DAKO Co., Califórnia, USA) como cromógeno, por 5 minutos; as lâminas foram lavadas em PBS, contra-coradas com hematoxilina de Harris por 15 segundos, lavadas com água destilada, desidratadas em concentrações crescentes de álcool e montadas em Permount ${ }^{\circledR}$.

Lâminas-controle foram utilizadas para testar a efetividade e especificidade da imunomarcação nas quais foi omitido a anticorpo primário e as lâminas foram incubadas com imunoglobulinas obtidas da mesma espécie animal na qual o anticorpo primário foi produzido. $O$ objetivo é avaliar a efetividade e especificidade das reações de TRAP, OPG e RANKL. Assim, funciona como uma contra-prova: se houver marcação no controle, provavelmente a imunomarcação das outras proteínas são inespecíficas. Não havendo marcação no controle, as marcações das demais proteínas são consideradas específicas. A coloração em hematoxilina e eosina também foi utilizada como uma referência para a citoarquitetura dos cortes analisados.

\subsection{Análise dos resultados}

\subsubsection{Descrição histológica (análise qualitativa)}

As análises foram realizadas qualitativamente em microscópio de luz. As faces mesial e distal da raiz foram consideradas. Observou-se as características do ligamento periodontal, osso alveolar, cemento, dentina, além da ocorrência de reabsorção inflamatória, anquilose e reabsorção por substituição. O periodonto de inserção foi didaticamente dividido em terço cervical, médio e apical para realizar a análise histológica e histométrica. Para análise microscópica descritiva, foram selecionadas aleatoriamente dez lâminas, contendo três cortes corados em cada uma, totalizando 30 cortes para cada tempo experimental. Os cortes corados pela técnica de H/E e TM foram analisados, por um único avaliador calibrado e cego ao 
tratamento realizado, através da microscopia de luz com a avaliações subjetivas das morfologias do contorno ósseo, gengival e ligamento periodontal, visualização do infiltrado inflamatório, presença de clastos, dos fibroblastos, áreas de hialinização, organização das fibras colágenas, dos vasos sanguíneos e formação do tecido osteóide. Para análise das fibras colágenas foi utilizada a coloração de TM.

A leitura das estruturas histológicas foi realizada com 0 auxilio do microscópio óptico HM-LUX (Wild Leitz, Periplan), com as seguintes resoluções: 10 NF X 4.0, para visualização panorâmica do preparo histológico; $10 \mathrm{NF} \times 10$, para identificação e visualização das estruturas do osso neoformado e $10 \mathrm{NF} X 20$, para identificação das células e demais estruturas.

Após a análise, as imagens histológicas em H/E e TM foram capturadas para análise, com o auxílio do microscópio Olympus BX-BX61 (Olympus, Tokio, Japão) acoplado a uma câmera de captação de imagem (Olympus, Tokio, Japão) conectada a um microcomputador DELL ${ }^{\circledR}$ (Dell Inc., Round Rock, USA), com software DP2$\mathrm{BSW}^{\circledR}$ (Olympus) para captura e análise de imagens digitalizadas.

O objetivo da análise histológica foi investigar os eventos morfológicos que ocorreram no interior do periodonto de inserção, focando na presença de remodelação óssea. A vitalidade do tecido conjuntivo e ósseo foi observada por meio da análise microscópica com auxílio do microscópio de transmissão de luz e considerou-se como critério de avaliação qualitativa a observação de tecido conjuntivo com presença de camada de osteoblastos delimitando as bordas ósseas, com vasos sanguíneos, fibroblastos e outros tipos celulares na porção central desse tecido, áreas de fibras colágenas, presença ou não de processo inflamatório, formação e organização do tecido conjuntivo, ósseo e medular, e remodelação óssea.

\subsubsection{Análise histométrica}

Para a histometria das reações de imunoistoquímica, a região do terço médio do periodonto de inserção foi escolhida, pois o processo de reparo alveolar ocorre de maneira mais homogênea nesta região (Okamoto e de Russo, 1973; Carvalho e Okamoto, 1987), evitando dessa forma o terço cervical, em virtude da interferência do ato cirúrgico nessa região, pelo uso do instrumental, para a abertura da sutura palatina mediana. 
Para a realização da análise histométrica, foi utilizado o método "estereológico" ou "casualização de amostra" que consiste em determinar parâmetros quantitativos tridimensionais de estruturas anatômicas a partir de cortes histológicos, com intuito de eliminar a ocorrência de vício na amostragem. O referido método baseia-se no princípio geométrico-estatístico, derivados da probabilidade das imagens e dos perfis da estrutura no corte histológico, resultando num sistemateste efetivo. Portanto, realizaram-se os procedimentos de escolhas aleatórias para as seguintes fases do experimento: seleção dos animais, dos blocos histológicos, das lâminas histológicas, dos cortes e campos histológicos.

Todas as medidas foram realizadas por um mesmo pesquisador que desconhecia os grupos experimentais e os tratamentos realizados. O pesquisador foi submetido a um rigoroso processo de calibração pela repetição de mensurações, em um intervalo de 48 horas, utilizando $10 \%$ do total das imagens digitais, selecionadas aleatoriamente. A calibração foi aceita se a concordância existente entre as medidas iniciais e aquelas realizadas após 48 horas era maior ou igual a 90\%.

Nas lâminas onde foram realizadas as reações imunoistoquímicas foi realizada análise dos dados de forma semi-quantitativa, para mensurar o nível de intensidade da expressão das proteínas (marcação ausente, discreta, moderada e intensa) onde foram considerados com "escores" padrão contendo fotos representativas das intensidades: score $0(0 \%)$ para as lâminas que não apresentaram nenhuma marcação, score 1 (1\%-30\%); score 2 (31\%-60\%) e score 3 (61\%-100\%) de intensa marcação. Para a análise qualitativa foram levados em consideração os tipos celulares marcados positivamente pelas proteínas analisadas.

\subsubsection{Método e critérios para leitura de lâminas}

As imagens obtidas das imunomarcações das proteínas TRAP, OPG e RANKL de todos os grupos estudados foram comparadas através da contagem de células positivas utilizando o "software" IMAGEJ 1.28u (programa de domínio público desenvolvido por Wayne Rasband NIMH, NIH,U.S.A.). Os cortes teciduais submetidos à imunomarcação (cor marrom) foram avaliados quanto a intensidade, presença ou a ausência das imunomarcações. Para a análise qualitativa foram levados em consideração os tipos celulares marcados positivamente pelas proteínas analisadas. As secções histológicas foram analisadas sob iluminação de campo claro em microscópio óptico (Olympus BX-BX61, Tokio, Japão) por um investigador 
que desconhecia os grupos experimentais que foram analisados. Para a realização da análise semi-quantitativa foi realizada contagem do número das células imunorreativas para os anticorpos TRAP; OPG e RANKL para cada grupo e período estudado. $O$ número de osteoclastos $/ \mu \mathrm{m}^{2}$ e células precursoras de osteoblastos $/ \mu \mathrm{m}^{2}$ do tecido ósseo na região do ligamento periodontal $(\mathrm{Nm})$ foi determinada no sistema de análise IMAGE J. Foram consideradas células imuno positivas osteoclastos maduros contendo três ou mais núcleos e células osteoblásticas e precursoras de osteoblastos. A imunomarcação foi definida como aquela de coloração acastanhada presente no compartimento nuclear das células ou no compartimento citossólico das células.

Cada espécime foi mensurada por um examinador calibrado em sistema de duplo cego usando método semi-quantitativo a partir de imagens capturadas no microscópio Olympus BX-BX61 (Tokio, Japão) acoplado a um computador DELL ${ }^{\circledR}$ (Dell Inc., Round Rock, USA), através do programa DP2-BSW ${ }^{\circledR}$ (Olympus). Os seguintes critérios foram usados para padronizar a análise histométrica: 1) análise de apenas cinco lâminas (10 cortes histológicos) de cada animal; 2) delimitação de vinte campos (alvéolo mesio-vestibular e mésio-palatino) de tamanhos equivalentes no terço médio do alvéolo; 3) padronização no tamanho e posição dos campos.

\subsection{Precisão da Metodologia (Calibração do examinador)}

Para a confiabilidade dos resultados desse trabalho, procurou-se minimizar os erros dos métodos de mensuração empregados. Calculou-se a precisão do investigador pelo erro sistemático intraexaminador. O erro sistemático reflete uma falta de padronização do método, uma vez que o examinador tende a sub ou superestimar os valores de suas medições de maneira inconsciente, de modo a direcionar os resultados de acordo com as expectativas em relação às conclusões do estudo. Para avaliar a calibração do examinador, nas mensurações de cada espécime, foi realizada, previamente às leituras finais, a correlação intraclasse. Vinte cortes foram aleatoriamente selecionados e suas contagens foram feitas e repetidas três semanas após a primeira medição pelo mesmo examinador. A análise de variância para dados repetidos (one-way ANOVA) foi usada para verificar o erro intraexaminador sistemático do método (Erro do método), por meio da comparação dos valores das duas análises distintas com intervalo de 30 dias, independente do grupo e do tempo. Valores de $\mathrm{p}<0,05$ foram considerados para estimar a viabilidade 
de utilização do método proposto. Assim, observou-se que erros na verificação da precisão desse estudo foram admissíveis, promovendo resultados fidedignos.

\subsection{Análise Estatística}

A hipótese de não haver diferença estatisticamente significante na taxa de expressão protêica no periodonto de inserção entre os diferentes períodos e tipo de tratamento entre os grupos foi testada. A análise estatística foi realizado com o programa de estatística GraphPad Prism versão 5 (GraphPad Software Inc., San Diego, CA, EUA), tendo sido adotado o nível de significância de $5 \%(p<0,05)$ para que as diferenças fossem consideradas estatisticamente significativas, ou seja, para rejeitar a hipótese nula.

$\mathrm{Na}$ análise intra-grupo o teste paramétrico de análise de variância (OneWay ANOVA) foi utilizado e, quando detectada diferença estatisticamente significante foi utilizado o teste paramétrico de Tukey-Kramer, detectando assim a diferença significativa entre os grupos dentro do mesmo ensaio.

Para as medidas em escores os dados foram agrupados e apresentados em medianas, intervalos interquartil, e os valores mínimos (variáveis ordinais) e máximo. O teste Kruskal-Wallis e os testes de Dunn $(p<0,05)$ foram utilizados para os escores. 

4. Resultados 



\section{RESULTADOS}

\subsection{Avaliação Clínicas}

Durante avaliação clínica, pôde-se notar que em todos os animais sem a ERM, a gengiva marginal livre apresentava-se sadia, sem sinais clínicos de inflamação ou ulceração. Não se observou separação dos pontos de contato entre os incisivos centrais, apenas na região cervical, onde estava presente a papila interdental, compatível com a normalidade, achados estes que foram confirmados na avaliação histológica.

Nos animais submetidos à ERM, após a remoção do aparelho ortodôntico que estava fixado nos incisivos centrais superiores, observou-se a demarcação do grampo sobre a mucosa fina, sem áreas de ulceração, porém com a presença de leve hiperplasia gengival. Além disso, pôde-se notar clinicamente a separação do ponto de contato entre os incisivos superiores. Estes resultados foram confirmados pelos exames histológicos e em radiografias da maxila realizadas anteriormente pelo nosso grupo de pesquisa (Okada, 2012; Arnez, 2014; Monteiro, 2017). Estes exames radiográficos foram realizados no momento da eutanásia para certificar-se da eficácia da ERM e manuntenção com dispositivo ortodôntico. A sutura palatina mediana nos grupos controle se apresentava intacta, e nos grupos ERM, apresentava-se aberta.

\subsubsection{Análises clínicas (glicemia, peso e consumo hdrico)}

Os animais foram separados por grupos (diabéticos, não-diabéticos e diabéticos tratados) e subgrupos (com ERM e sem ERM) e mantidos em número de 3 por gaiola, todos nas mesmas condições de temperatura, luz, alimentação e higiene; tiveram o peso, consumo hídrico e as taxas glicêmicas monitorados durante todo o experimento. 


\subsubsection{Glicemia}

Consideramos a taxa glicêmica acima de $300 \mathrm{mg} / \mathrm{dl}$ para os animais diabéticos. As taxas de glicemia dos ratos mensuradas após a indução e antes da eutanásia mostraram que os ratos diabéticos mantiveram em estado diabético no início e no final do experimento, apresentando um valor aproximadamente três a quatro vezes maiores em relação aos ratos normais. Esses dados foram importantes apenas para indicar a manutenção do estado diabético, não sendo necessário efetuar comparações estatísticas (Tabela 2).

Durante todo o experimento não houve alterações relevantes nas taxas glicêmicas dos animais do grupo DM e DM+ERM, onde a média glicêmica após a indução do diabetes foi de $439,33 \mathrm{mg} / \mathrm{dl}$ e de $460,67 \mathrm{mg} / \mathrm{dl}$, respectivamente. Nos animais dos grupos diabéticos tratados com insulina, as taxas glicêmicas tiveram alguma redução. A média glicêmica dos animais do grupo DM+INS após a administração da insulina foi de $285,3 \mathrm{~g} / \mathrm{dl}$.

Os valores glicêmicos foram estatisticamente diferentes quando se comparou os grupos C x DM, ERM x DM+ERM após 2 e 28 dias da indução ao diabetes e nos períodos de 3, 7 e 10 dias após a instalação dos aparelhos ortodônticos $(p<0,05)$, isto é os grupos diabéticos com ou sem disjunção apresentaram níveis glicêmicos mais elevados comparado aos grupos controles. Entretanto não se observou diferença nos índices glicêmicos no grupo $\mathrm{C}$ comparado ao grupo ERM, DM x DM+ERM ( $p>0,05)$ (Tabela 2).

Tabela 2- Avaliação glicêmica ( $\mathrm{mg} / \mathrm{dl})$ nos diferentes grupos de estudo e tempos de avaliação

\begin{tabular}{lcccccc}
\hline \multicolumn{1}{c}{ Grupo } & $\begin{array}{c}\text { Média } \pm \text { DP } \\
\text { Inicial }\end{array}$ & $\begin{array}{c}\text { Média } \pm \text { DP } \\
\text { 2 dias }\end{array}$ & $\begin{array}{c}\text { Média } \pm \text { DP } \\
\text { 28 dias }\end{array}$ & $\begin{array}{c}\text { Média } \pm \text { DP } \\
\text { 3 dias }\end{array}$ & $\begin{array}{c}\text { Média } \pm \text { DP } \\
\text { dias }\end{array}$ & $\begin{array}{c}\text { Média } \pm \text { DP } \\
\text { 10 dias }\end{array}$ \\
\hline Controle (C) & $93,3 \pm 14,58$ & $88 \pm 10,76$ & $91,4 \pm 9,99$ & & & \\
DM & $89,8 \pm 12,46$ & $411,1 \pm 51,25$ & $467,5 \pm 82,24$ & & & \\
DM+INS & $90,26 \pm 11,76$ & $358,5 \pm 38,41$ & $575,1 \pm 44,55$ & $193,8 \pm 41,59$ & $240,9 \pm 134,71$ & $421,2 \pm 64,75$ \\
ERM & $99,3 \pm 10,92$ & $92,1 \pm 12,70$ & $105,3 \pm 14,63$ & & & \\
DM+ERM & $102,9 \pm 12,63$ & $415,5 \pm 92$ & $505,9 \pm 97,16$ & & & \\
DM+INS+ERM & $89,8 \pm 9,86$ & $365,1 \pm 37,14$ & $543,6 \pm 68,89$ & & $201,8 \pm 170,52$ & $545,6 \pm 73,96$ \\
\hline
\end{tabular}

\subsubsection{Peso Corporal}

Os animais não diabéticos, após a administração de tampão citrato, apresentaram-se sem alterações clínicas na saúde geral durante o experimento, com ganho de peso dentro dos níveis médios esperados para ratos sadios, além de 
não apresentaram clinicamente sinal de polifagia, poliúria ou polidipsia. Todos os animais deste grupo tiveram níveis glicêmicos estáveis, dentro do padrão de normalidade, sem diferença significativa entre eles, durante todos os períodos experimentais. Os animais diabéticos após a administração de STZ, apresentaram parâmetros clínicos gerais compatíveis com diabetes grave, como caquexia e progressiva perda de peso. Esta perda de peso foi significativa quando comparada com os animais não diabéticos. Nos animais dos grupos DM e DM+ERM a perda de peso foi mais acentuada quando comparada aos grupos DM+INS e DM+INS+ERM, que receberam doses de insulina. Ainda com relação ao peso corporal, após o início do tratamento com insulina, os animais do grupo DM+INS e DM+INS+ERM, pararam de perder peso e observamos uma tendência a ganhar peso (Tabela 3).

Ao comparar os grupos C x DM, observou-se diferença estatisticamente significante no peso dos animais nos períodos de 28 dias de avaliação e nos períodos de 3, 7 e 10 dias de eutanásia $(p<0,05)$, isto é, os animais diabéticos perderam peso durante o estudo, ao passo que os animais do grupo controle tiveram um ganho de peso durante os tempos de avaliação. Este mesmo padrão de resultado foi observado quando se comparou os grupos, $\operatorname{ERM} \times \mathrm{DM}+\mathrm{ERM}(p<0,05)$. Por outro lado, não houve diferença estatística entre os pesos dos animais $C \times E R M$ e DM $\times$ DM+ERM $(p>0,05)$, isto é, os animais do grupo controle, assim como os animais dos demais grupos submetidos ou não à disjunção apresentaram pesos similares durante todo o desenvolvimento da pesquisa.

Em resumo, os animais dos grupos não diabéticos submetidos ou não à disjunção ganharam peso $(p<0,05)$ nos tempo de 28 dias e nos períodos de 3,7 e 10 dias de eutanásia, porém, os animais diabéticos com ou sem disjunção perderam peso nestes períodos $(p<0,05)$ (Tabela 3$)$.

Tabela 3- Avaliação do peso corporal (g) nos diferentes grupos de estudo e tempos de avaliação

\begin{tabular}{lcccccc}
\hline \multicolumn{1}{c}{ Grupo } & $\begin{array}{c}\text { Média } \pm \text { DP } \\
\text { Inicial }\end{array}$ & $\begin{array}{c}\text { Média } \pm \text { DP } \\
\text { 2 dias }\end{array}$ & $\begin{array}{c}\text { Média } \pm \text { DP } \\
\text { 28 dias }\end{array}$ & $\begin{array}{c}\text { Média } \pm \text { DP } \\
\text { dias }\end{array}$ & $\begin{array}{c}\text { Média } \pm \text { DP } \\
\mathbf{7} \text { dias }\end{array}$ & $\begin{array}{c}\text { Média } \pm \text { DP } \\
\text { 10 dias }\end{array}$ \\
\hline Controle (C) & $343,8 \pm 19,76$ & $348,9 \pm 19,67$ & $499,2 \pm 36,57$ & $526,4 \pm 36,36$ & $544,1 \pm 41,38$ & $563 \pm 54,74$ \\
DM & $319,4 \pm 25,70$ & $313,5 \pm 23,70$ & $319,1 \pm 41,93$ & $342,6 \pm 44,46$ & $326,2 \pm 50,43$ & $318,6 \pm 46,82$ \\
DM+INS & $354,7 \pm 24,98$ & $324,5 \pm 26,46$ & $276,8 \pm 40,72$ & $296,5 \pm 42,08$ & $305,2 \pm 39,39$ & $321,4 \pm 47,79$ \\
ERM & $418,3 \pm 58,73$ & $407,2 \pm 52,19$ & $547,9 \pm 36,95$ & $549,2 \pm 43,23$ & $533,6 \pm 33,93$ & $519,4 \pm 51,22$ \\
DM+ERM & $376 \pm 21,54$ & $359,9 \pm 20,18$ & $300,7 \pm 30,82$ & $318,3 \pm 29,98$ & $333,4 \pm 45,20$ & $303,8 \pm 25,60$ \\
DM+INS+ERM & $320,5 \pm 20,72$ & $303 \pm 30,40$ & $260,8 \pm 40,73$ & $280,9 \pm 38,92$ & $282,1 \pm 37,87$ & $313 \pm 36,38$ \\
\hline
\end{tabular}




\subsubsection{Consumo hídrico}

Avaliando-se o consumo hídrico dos animais observou-se diferença estatística quando se comparou os grupos C x DM, ERM $\times$ DM+ERM após 2 e 28 dias da indução ao diabetes e nos períodos de 3, 7 e 10 dias após a instalação dos aparelhos ortodônticos $(p<0,05)$, isto é, os grupos diabéticos com ou sem disjunção apresentaram maior consumo de água comparado aos grupos controles. Para os grupos DM $\times$ DM+ERM observou-se maior consumo de água nos animais do grupo DM nos tempos de 28 dias de validação e 7 dias de eutanásia $(p<0,05)$. Entretanto não se observou diferença no consumo hídrico dos animais do grupo $C \times E R M$ $(p>0,05)$ (Tabela 4).

Tabela 4- Avaliação do consumo hídrico $(\mathrm{mL})$ nos diferentes grupos de estudo durante todo o experimento

\begin{tabular}{lcccccc}
\hline \multicolumn{1}{c}{ Grupo } & $\begin{array}{c}\text { Média } \pm \text { DP } \\
\text { Inicial }\end{array}$ & $\begin{array}{c}\text { Média } \pm \text { DP } \\
\text { 2 dias }\end{array}$ & $\begin{array}{c}\text { Média } \pm \text { DP } \\
\text { 28 dias }\end{array}$ & $\begin{array}{c}\text { Média } \pm \text { DP } \\
\text { 3 dias }\end{array}$ & $\begin{array}{c}\text { Média } \pm \text { DP } \\
\mathbf{7} \text { dias }\end{array}$ & $\begin{array}{c}\text { Média } \pm \text { DP } \\
\text { 10 dias }\end{array}$ \\
\hline Controle (C) & $44,3 \pm 16,59$ & $51,1 \pm 13,57$ & $67 \pm 0$ & $63,6 \pm 7,03$ & $58,5 \pm 12,02$ & $60,2 \pm 9,31$ \\
DM & $67 \pm 0$ & $160,8 \pm 51,04$ & $154,4 \pm 30,90$ & $176,7 \pm 40,60$ & $229,4 \pm 60,99$ & $219,8 \pm 50,39$ \\
DM+INS & $67 \pm 0$ & $102,1 \pm 17,54$ & $217,7 \pm 42,89$ & $226,7 \pm 40,60$ & $210 \pm 21,08$ & $200 \pm 0$ \\
ERM & $67 \pm 0$ & $59,6 \pm 14,32$ & $53,7 \pm 16,11$ & $63,3 \pm 28,13$ & $60 \pm 17,48$ & $55 \pm 11,18$ \\
DM+ERM & $55,7 \pm 16,59$ & $134,4+31,23$ & $116,8 \pm 18,96$ & $164,7 \pm 37,10$ & $147,4 \pm 44,31$ & $160 \pm 54,77$ \\
DM+INS+ERM & $67 \pm 0$ & $116,8 \pm 39,80$ & $138,7 \pm 25,71$ & $164,3 \pm 34,60$ & $183,3 \pm 28,44$ & $200 \pm 61,23$ \\
\hline
\end{tabular}

\subsection{Descrição histológica qualitativa}

A fim de permitir a comparação, as ocorrências verificadas nos grupos controle e experimentais foram apresentadas juntas seguindo-se os períodos cronológicos de eutanásia dos animais. Os resultados obtidos pelo grupo controle foi similar para todos os tempos de estudo, devido à ausência de aplicação de força ortodôntica. Assim sendo, foram descritos, após análise, as seguintes estruturas: ligamento periodontal, cemento radicular e tecido ósseo.

\subsubsection{Grupo Controle (C)}

O exame histológico do periodonto de sustentação dos dentes dos animais do Grupo Controle mostrou características de normalidade destas estruturas, que serviram como comparativo com os animais dos demais grupos. As características do Grupo Controle nos diferentes períodos (3, 7 e 10 dias) foram descritas juntas.

$\mathrm{Na}$ identificação de cada componente do periodonto, os cortes histológicos revelaram a delgada camada de cemento acelular uniforme, regular e íntegra 
presente no terço cervical e médio da superfície radicular. O cemento celular, também distribuído de modo regular, ocupava principalmente o terço médio e apical da raiz, caracterizado pela presença de cementócitos no seu interior. Lacunas (cementoblastos) vazias foram encontradas nas camadas mais profundas do cemento, principalmente no ápice radicular, ou contendo cementócitos. Estes conferem ao cemento celular desta região, aspecto mais celularizado. Entre os espécimes, notaram-se, pequenas variações relativas à espessura e à extensão, de cada tipo de cemento. A espessura do cemento aumentou, gradativamente, da região cervical em direção apical, onde a camada do mesmo era mais espessa. Ao longo de toda superfície externa do cemento, recobrindo-a, verificou-se uma fina camada de tecido cementário recoberta por cementoblastos inativos (células achatadas e com núcleos paralelos à superfície radicular e pouco evidentes) e alguns cementoblastos ativos (células grandes, arredondadas contendo núcleos volumosos e de coloração mais intensa) enfileirados, geralmente de maneira organizada. Por entre estes cementoblastos, foi evidenciado o sistema de fibras de Sharpey, oriundas do ligamento periodontal, que inseriam-se, na sua maioria, perpendicularmente ao cemento, atingindo suas camadas mais profundas. Não se observou presença de reabsorção nas superfícies radiculares, evidenciando nos terços cervical e apical radicular camada de cemento acelular e celular preservada. (Figura 3, página 85).

O espaço periodontal apresentou espessura uniforme ao redor das raízes de todos os dentes. O ligamento periodontal mostrou-se com abundância de fibras colágenas e estas estavam mergulhadas, tanto no cemento quanto no osso alveolar, de tal forma que foi possível verificar nítida conexão entre os tecidos conjuntivos mineralizados do periodonto. A maioria das fibras penetrava, perpendicularmente, ao osso e ao cemento e, projetava-se para o centro do espaço periodontal, nas mais diversas direções, onde formava um emaranhado na região central do espaço periodontal. A distribuição das fibras periodontais foi, facilmente, verificada nos cortes histológicos, sendo que o grupo das fibras horizontais era o mais abundante e o mais espesso. O plexo vásculo-nervoso, irregularmente distribuído localizava-se a meia distância entre o osso alveolar e o cemento, porém, o tecido conjuntivo, próximo ao osso, apresentou-se mais rico em vasos do que o tecido conjuntivo que revestia o cemento. Os vasos sangüíneos, normalmente, seguiam a orientação dos feixes de fibras e apresentaram-se com luz circular ou levemente ovaladas e 
repletos de células sangüíneas. A camada compacta do osso da parede do alvéolo apresentou-se rica em perfurações, através das quais os vasos oriundos dos espaços medulares subjacentes penetravam no ligamento periodontal. $O$ ligamento periodontal apresentou-se densamente celular com predominância de fibroblastos distribuídos por todo o espaço periodontal, que observados em maiores aumentos, alinhavam-se ao longo dos feixes de fibras, individualizando-se pelo seu grande tamanho e núcleo em forma de fuso. Também foram observadas as células mesenquimais indiferenciadas, osteoblastos de tamanho discreto, dispostos em fileiras únicas junto das camadas de osteóide e cementoblastos (Figura 3, página 85).

A superfície interna do processo alveolar era lisa em seu contorno e estava bem regular e organizado, exceto por perfurações que podiam ser observadas na superfície óssea, devido à irrigação proveniente dos espaços medulares subjacentes, penetrando no ligamento periodontal. Este osso caracterizava o osso fasciculado (imaturo) sustentando a inserção das fibras ligamentares no lado alveolar. O terço cervical da crista óssea alveolar caracterizou-se por osso predominantemente compacto com vários sistemas de Havers organizados e circundados por escassas e pequenas cavidades medulares, preenchidas por tecido conjuntivo fibroso. No terço apical a quantidade de osso esponjoso era maior. Este situava-se na parte central do processo alveolar, constituído por delgadas trabéculas ósseas, compostas de lamelas intersticiais e com a ocorrência, também, de alguns sistemas harvesianos. Nesta região, as cavidades medulares eram amplas e com células mesenquimais e osteoblastos em seu interior. Todo o osso lamelar apresentou-se recoberto por camada fina e irregular de osso não lamelar com matriz orgânica ainda em calcificação mostrando grande número de osteócitos já bem definidos. Justaposta à camada de osso não lamelar, foi verificada fina camada de osteóide. Grande número de osteoblastos, de corpo celular cubóide, recobria toda a extensão desse tecido osteóide. (Figura 3, página 85).

\subsubsection{Grupo Diabetes mellitus (DM)}

Embora as características histológicas do DM foram bastante semelhantes às do grupo controle, foram notadas algumas alterações na morfologia normal do ligamento periodontal, vascularização e osso alveolar. 
As superfícies dentárias mostraram-se preservadas, uniformes inclusive com tecido cementário, revestido por cementoblastos, dispostos ao acaso, em paliçada, predominantemente justapostos à superfície, não ocorrendo modidicações nucleares dignas de registro. As áreas de absorção radicular eram raras e, quando presentes, discretas e rasas, sem extensão para a camada dentinária. O cemento acelular apresentou-se de modo geral, pouco espesso e regular, mostrando camada nítida de pré-cemento. No tipo celular notou-se espessura variável, maior em direção ao ápice radicular (Figura 3, página 85).

No ligamento periodontal duas áreas distintas foram observadas: a primeira camada, próxima ao cemento, era extremamente celular com predomínio de fibroblastos jovens, com núcleos arredondados e volumosos quando comparado ao GC com uma discreta perda de orientação de fibras colágenas; a segunda camada, voltada para o osso alveolar, notou-se predomínio de fiblobrastos com morfologia alongada ou estrelada e, maior quantidade de fibras, de morfologia semelhante aos do GC. Os fibroblastos, em menor número nesta última camada, apresentavam núcleo alongado e estavam posicionados entre as fibras colágenas. Nesta camada, a quantidade de vasos sanguíneos estava aumentada, e com sinais de hiperemia e, estes eram mais numerosos no grupo diabético do que no GC, em toda extensão da membrana periodontal. As fibras colágenas estavam preservadas em toda extensão do ligamento periodontal, tanto na face mesial como na distal das raízes, porém com maior perda de orientação e se apresentavam mais delgadas no grupo diabético em comparação com o controle. A superfície do osso alveolar, voltada para o ligamento periodontal, apresentou contorno levemente irregular, com linhas incrementais em maior número, sem orientação definida. Osteócitos e suas lacunas apresentaram características normais. Às margens do tecido ósseo foram observados alguns osteoblastos ativos (Figura 3, página 85).

\subsubsection{Grupo Diabetes mellitus + Insulina (DM+INS)}

Os animais tratados com insulina apresentaram, características histológicas semelhantes àquelas visualizadas no DM, porém menos marcadas.

Os cortes microscópicos analisados revelaram ligamento periodontal com largura constante e uniforme em toda sua extensão. Suas fibras colágenas mantiveram-se, em geral, paralelas entre si inserindo-se perpendicularmente, às superfícies óssea e cementária. A superfície cementária apresentou-se uniforme e 
revestida por cementoblastos dispostos em paliçada, geralmente de maneira organizada, não sendo observadas lacunas de reabsorção. A superfície radicular dos terços cervical e apical possuía camada de cemento acelular preservada, com raras áreas de reabsorções atingindo cemento. A camada de cemento celular presente na região apical também se encontrava preservada. No ligamento periodontal, novamente, foram observadas duas áreas distintas, porém de forma mais tênue. A primeira camada, próxima ao cemento, altamente celular, com predomínio de fibroblastos de núcleos arredondados com cromatina finamente granular e a segunda, próxima ao osso alveolar, com maior quantidade de fibras. $\mathrm{Na}$ segunda camada preodominava fibroblastos, em menor número, com núcleo alongado e estavam em paralelismo com as fibras. Áreas hialinas não foram visualizadas e raras mitoses dos fibroblastos foram detectadas. Os vasos sanguíneos estavam distribuídos por todo o ligamento, com tamanho variado, e alinhados às margens do tecido ósseo (Figura 3 , página 85 ).

A superfície do osso alveolar voltada para o ligamento apresentou contorno levemente irregular, discretamente recortada, com poucos clastos dispostos em lacunas de Howship ou justapostos à superfície. Os osteoblastos dispunham-se justapostos à superfície arranjados em paliçada. As linhas de reversão estavam presentes em toda extensão óssea. O osso maduro apresentou maior número de linhas incrementais e osteócitos de tamanho normal. O que diferenciou o Grupo Controle do Grupo Diabético com e sem Insulina, foi a grande presença de vasos sanguíneos hiperêmicos no interior do ligamento periodontal nos animais diabéticos. Esses vasos hiperêmicos estavam mais próximos ao osso alveolar do que da superfície radicular (Figura 3, página 85). 
Figura 3- Fotomicrografias dos Grupos controles, não submetidos à ERM (C, DM e DM+INS) de 3 , 7 e 10 dias após o começo do período experimental: O tecido ósseo, LP - ligamento periodontal com fibras colágenas, vasos sanguíneos e células, d - dente, seta- vaso sanguíneo hiperêmico. Coloração de HE e Masson

\section{GRUPO CONTROLE}

CONTROLE
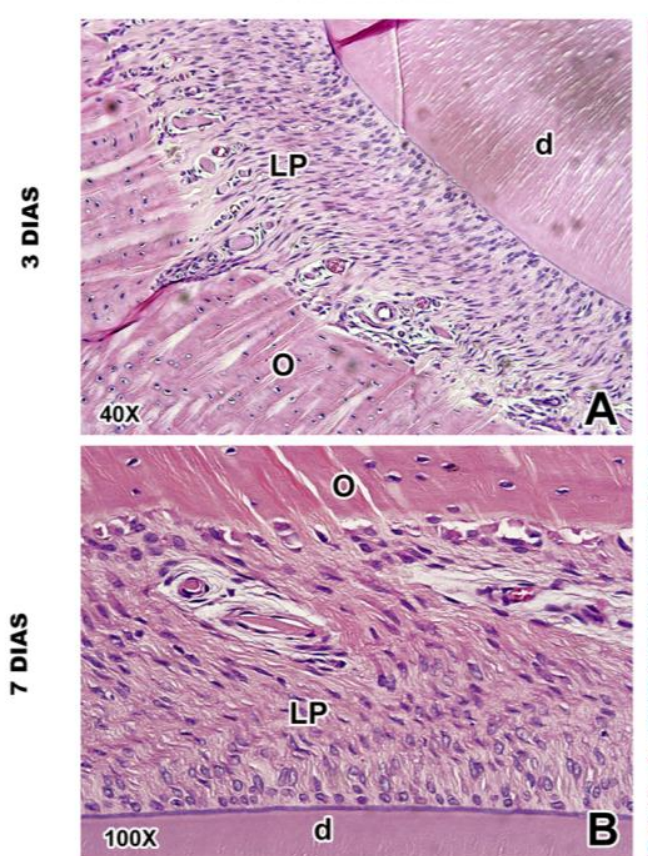

B
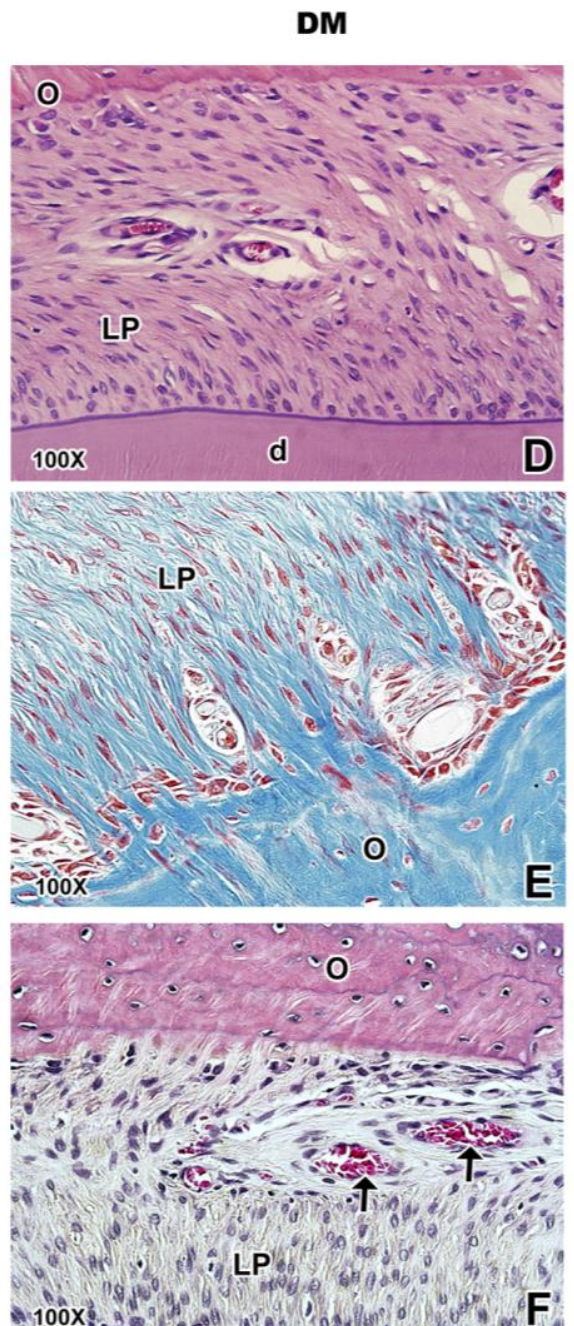

DM + INS
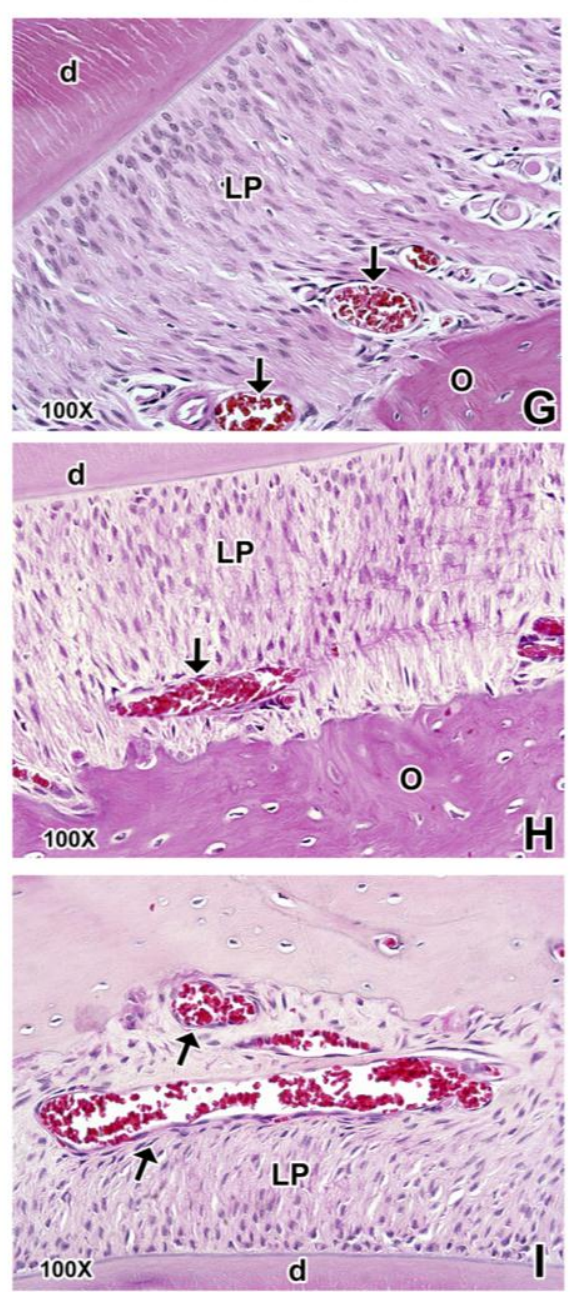



\subsubsection{Grupo Expansão Rápida da Maxila (ERM)}

As estruturas do periodonto de sustentação, frente à aplicação da força resultante da ERM, revelaram modificações expressivas nos seus componentes, em decorrência da força aplicada. Após a aplicação da força ortodôntica sobre a coroa dos incisivos superiores, ficou caracterizada a presença de áreas de pressão (face distal) e tração (face mesial) no ligamento periodontal deste dente, sendo esta maior no terço cervical e médio do que no terço apical, características do movimento de inclinação dentária. Microscopicamente, a gengiva marginal livre entre os incisivos centrais mostrou a instalação de processo inflamatório no seu interior, principalmente no período inicial de aplicação de força ortodôntica, verificado também ao exame clínico, porém, tal processo não invadiu o periodonto de inserção. Os quadros histológicos apresentados indicaram reações teciduais mais intensas nos períodos de 3 e 7 dias pós-movimentação, enquanto que no período de 10 dias, os quadros denotaram condições de reparação e tendência para retornar à normalidade.

\subsubsection{Animais submetidos à eutanásia 3 dias após ERM}

No lado de pressão, na sua maior parte, a superfície dentária mostrou-se com cemento acelular, fino e uniforme, revestido por cementoblastos. Alguns focos de absorção cemento-dentinária, com intensidade e tamanho variando de discreto a intenso, foram observados, principalmente no terço apical, onde predominava o cemento celular. A largura do ligamento periodontal mostrou-se bastante diminuída, com poucos núcleos corados, fibras desorganizadas e comprimidas impossibilitando a identificação, poucos capilares e presença de algumas áreas de hialinização. Numa camada mais profunda, observou-se quantidade discreta de fibroblastos e de capilares, predominando um infiltrado inflamatório com polimorfonucleares neutrófilos estendendo até o nível da crista alveolar. Na superfície radicular, evidenciou-se poucos cementoblastos distribuídos, e poucos osteoblastos presentes no osso alveolar frontalmente à hialinização. Nos espaços medulares e nas superfícies do osso alveolar adjacente às áreas de hialinização, observou-se presença de células clásticas promovendo reabsorção óssea à distância (Figura 4 página 91).

No lado de tração, apresentava características semelhantes com alargamento do ligamento periodontal, que continham fibras colágenas estiradas, 
oblíquas e paralelas entre si, com maior quantidade de capilares em relação ao lado de pressão, além de fibroblastos fasciculados predominantemente fusiformes. Algumas áreas hemorrágicas foram observadas. De modo geral, a superfície radicular apresentou-se preservada com a camada de cemento acelular uniforme e contínua.

\subsubsection{Animais submetidos à eutanásia 7 dias após ERM}

No lado de pressão o cemento mostrou sinais de recuperação nas áreas de absorção prévia, com fibroblastos e cementoblastos acoplados à sua superfície e, depósito de tecido cementário. De modo geral, mostrou-se delgado e regular sem grandes áreas de absorção radicular, com exceção do ápice onde ainda mostrava cavidades contendo cementoclastos. Portanto, ainda foram notadas áreas de absorção radicular ativa atingindo tanto cemento quanto a dentina. Notou-se ainda, diminuição da largura do espaço do ligamento periodontal com compressão das fibras, capilares e células. Na área de concentração de maior pressão (região cervical da superfície distal) o ligamento apresentava baixa celularidade, fibras desorganizadas com características de massa amorfa e irrigação diminuída, formando áreas semi-hialinizadas. Em outras áreas as fibras do ligamento periodontal apresentaram-se com trajeto alterado. A superfície óssea submetida à pressão mostrou áreas de absorção variando de moderadas a intensas com presença de células multinucleadas do tipo osteoclásticas, bem como áreas de hialinização, mas com maior atividade clástica em sua volta. A absorção óssea ocorreu tanto na superfície periodontal, quanto na endosteal, com pequenas variações entre as regiões, sendo que na porção cervical, onde o osso era mais compacto predominou a absorção óssea frontal e o reparo iniciou-se de forma mais rápida. A superfície óssea apresentou-se irregular e com alguns osteoclastos recobrindo-a. Na região apical, onde havia a predominância de osso esponjoso, encontrou-se absorção óssea solapante, principalmente em associação com a formação de áreas hialinas. Os osteoclastos das cavidades medulares absorviam o tecido ósseo em direção ao espaço periodontal. Houve aumento do número de cavidades medulares, sendo que algumas se comunicavam com o ligamento periodontal, e proliferação intensa de osteoclastos nestas cavidades (Figura 4, página 91). 
No lado de tração observou-se aumento do espaço do ligamento periodontal; feixes de fibras colágenas distendidas e fibroblastos com núcleos mais alongados, demonstrando estiramento. Vasos sanguíneos estavam em maior número que no grupo controle e, alguns vasos apresentavam hiperemia e hemorragia. Raras figuras de mitoses, células polimorfonucleadas, mononucleadas e multinucleadas estavam presentes. Havia intensa neoformação óssea que, em algumas áreas, apresentou formação em camadas e, em outras, na forma de espículas orientadas na direção da força de tração. A superfície cementária mostrou-se predominantemente regular, com os cementoblastos arranjados em paliçada em quase toda a superfície cementária e justapostos em outras áreas.

\subsubsection{Animais submetidos à eutanásia 10 dias após ERM}

No lado de pressão, a superfície distal revelou algumas áreas de absorção radicular de pouca profundidade, no terço cervical, atingindo preferencialmente a camada de cemento, porém em sua maior extensão apresentou a camada de cemento íntegra. Na região apical as áreas de absorções eram maiores e mais profundas. A largura do ligamento periodontal mostrou-se ainda diminuída com fibras comprimidas, porém, às vezes, esta largura mostrou-se um pouco aumentada, principalmente na região da crista alveolar. No espaço periodontal restou apenas pequenas áreas hialinizadas e caracterizou por acentuada celularidade do ligamento periodontal, próximo ao tecido ósseo, com núcleos seguindo o longo eixo das fibras colágenas e bem demarcados. Na região apical era constante a presença de alguns macrófagos. Também foi verificada proliferação vascular, com vasos sangüíneos dilatados e hiperêmicos próximos à superfície óssea, conferindo boas condições de suprimento vascular. Feixes de fibras colágenas se mostravam delicados, dispersos, porém com orientação mais definida, nas regiões mais alargadas. A superfície óssea mostrou-se irregular com poucas lacunas de Howship e osteoclastos em seu interior. (Figura 4, página 91).

No lado de tração observou-se a partir deste período, aspecto de organização tecidual, onde predominava um tecido conjuntivo imaturo contendo proliferação fibroblástica e vasos neoformados. Indícios de linhas de neoformação óssea, que delimitavam o osso alveolar maduro e o tecido osteóide também foram observados, sendo que os osteoblastos estavam distribuídos ao longo da superfície óssea alveolar. $\mathrm{O}$ osso alveolar apresentava maiores quantidades de trabéculas 
quando comparado com o osso alveolar do grupo controle. Em algumas regiões o processo de neoformação óssea se apresentou com deposição em camadas e, em outras, na forma de espículas orientadas na direção da força de tração. O tecido ósseo recém-mineralizado tinha, aproximadamente, metade da espessura do osso maduro e podia ser distinguido deste pela presença das linhas incrementais, caracterizadas pela sua coloração mais rosada (Figura 4, página 91). 
Figura 4- Fotomicrografias do Grupo ERM, de 3, 7 e 10 dias pós-aplicação da força: O - tecido ósseo, LP - ligamento periodontal com fibras colágenas, vasos sanguíneos e células, d - dente, * tecido inflamatório e áreas hemorrágicas, seta - osteoclastos. Coloração de HE e Masson
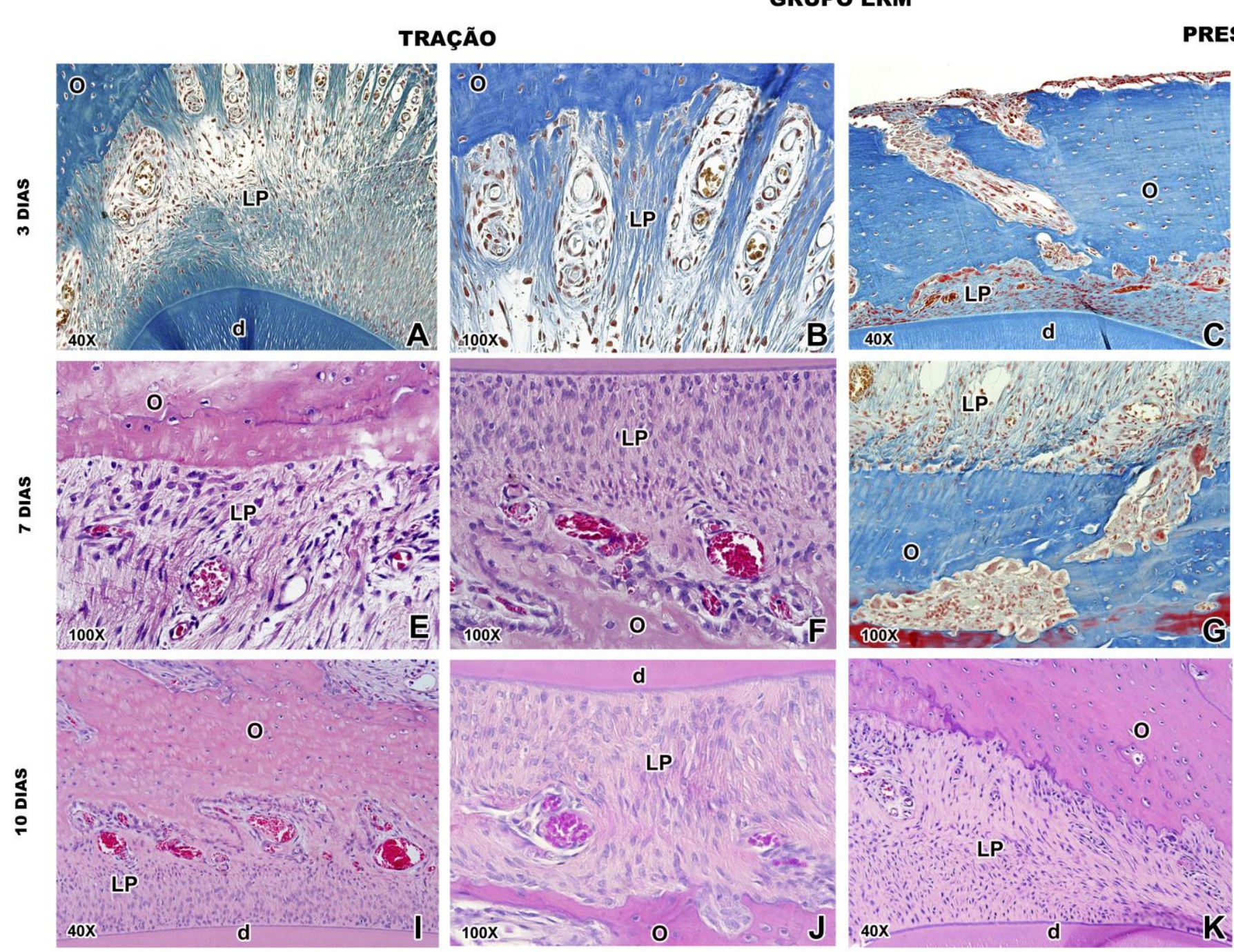

PRESSÃO
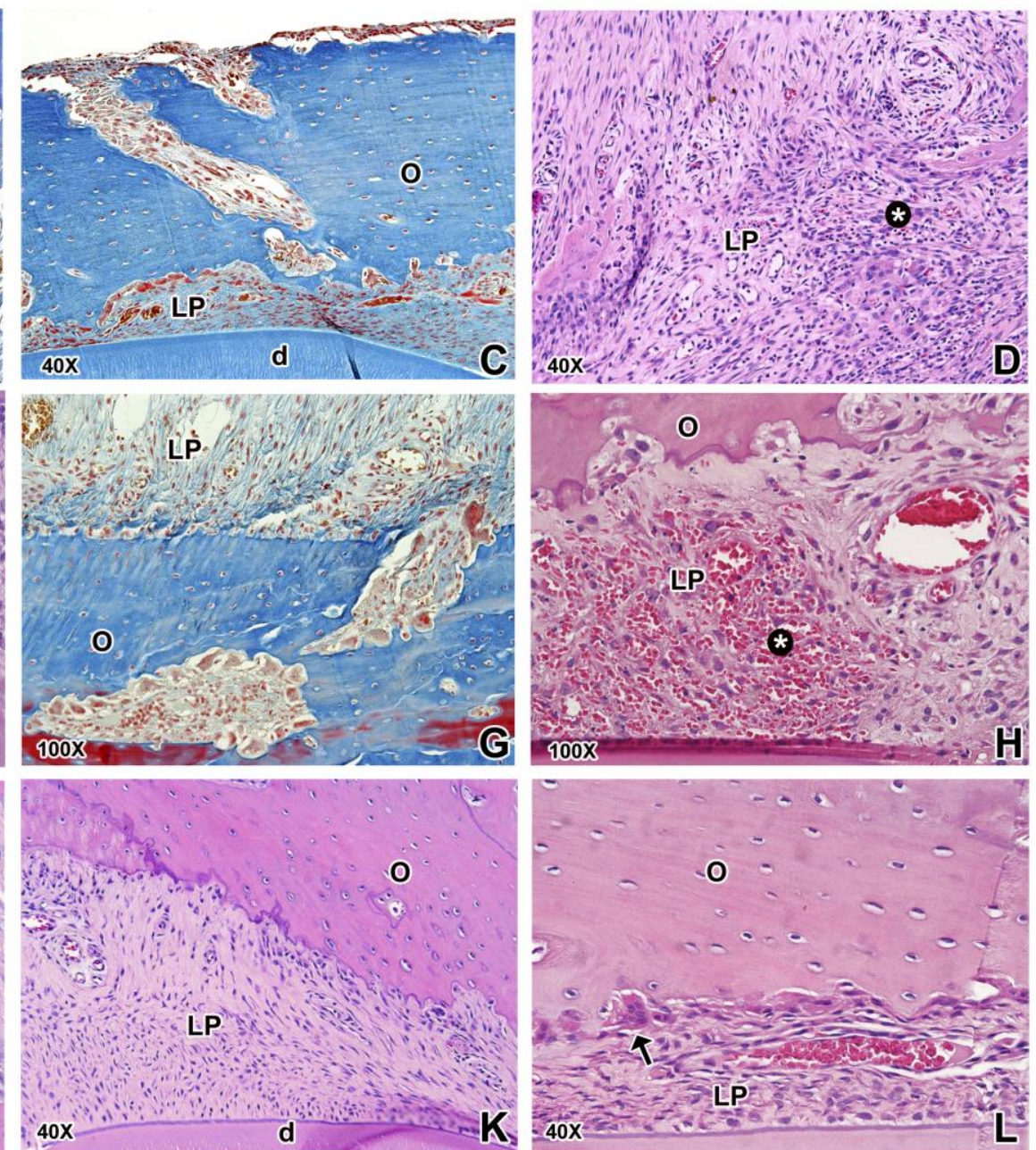



\subsubsection{Grupo Diabetes mellitus + Expansão Rápida da Maxila (DM+ERM)}

Numa vista panorâmica, observou-se que no grupo DM+ERM os movimentos dentários induzidos também foram predominantemente de inclinação, o mesmo observado no grupo ERM podendo presenciar na mesma face, distal ou mesial, de regiões de compressão e de tração.

O grupo DM+ERM apresentou alterações teciduais com uma magnitude inflamatória mais intensa em relação ao grupo ERM, devido à persistência do infiltrado inflamatório intenso na maioria dos animais avaliados, especialmente nas regiões cervicais, com a formação, até mesmo de seqüestros ósseos em alguns animais (Figura 5, página 97).

\subsubsection{Animais DM submetidos à eutanásia 3 dias após ERM}

No lado de pressão verificou-se a presença de lesões de profundidade maior do que no grupo ERM, na superfície do cemento acelular e algumas atingiram a camada de dentina. As áreas de absorção radicular eram mais intensas na região cervical onde a força de pressão foi maior, devido ao movimento de inclinação dentária, e, no ápice radicular, onde o cemento era altamente celular, sendo observado presença de clastos adjacentes às áreas de hialinização reabsorvendo o cemento. O ligamento periodontal mostrou-se de largura reduzida, com predomínio de vasos sangüíneos estreitos e feixes de fibras colágenas comprimidos e desorganizados e, algumas vezes, com perda de inserção no osso e no cemento, e havia início de perda de fasciculação de alguns fibroblastos, pois além de fusiforme, os fibroblastos mostraram-se, também, em forma ovalada e estavam distribuídos ao acaso. Havia pouca visualização de capilares, caracterizando áreas semihialinizadas, e na camada mais profunda, a presença de células inflamatórias estavam distribuídas por todo espaço do ligamento periodontal, predominando as mononucleares e neutrófilos polimorfonucleares. O osso alveolar, na região cervical (osso compacto) apresentou áreas típicas de zonas de pressão, com várias lacunas de absorção contendo osteoclastos multinucleados ativos em seu interior. Próximo a esta região houve aumento significativo da vascularização e do número de células, porém, mais evidente nos espaços medulares, na região apical. As áreas socavadas estavam preenchidas com tecido conjuntivo, densamente vascularizado com vasos de pequeno diâmetro. Os espaços medulares apresentavam-se recobertos por osteoclastos ativos, principalmente na região do terço apical onde os espaços 
medulares eram maiores e mostraram atividade de absorção mais intensa (Figura 5, página 97).

No lado de tração, observou-se um aumento da espessura do ligamento periodontal e, a superfície radicular apresentou-se preservada com a camada de cemento acelular uniforme e contínua em quase toda a sua extensão. As fibras colágenas estavam estiradas, mas bem orientadas, com maior quantidade de capilares em relação ao lado de pressão, sendo que alguns estavam hiperêmicos. Algumas áreas hemorrágicas foram observadas por entre as fibras colágenas estiradas. A superfície óssea na porção periodontal mostrou-se irregular, no entanto as cavidades reabsortivas estavam inativas, com presença de linhas de reversão. Os osteoblastos apresentavam-se em disposição aleatória e alguns justapostos (Figura 5, página 97).

\subsubsection{Animais DM submetidos à eutanásia 7 dias após ERM}

Da mesma forma que o período anterior, absorções radiculares foram encontradas. Estas áreas mostraram margens denteadas e irregulares, recobertas por cementoclastos, com profundidades variadas, ora atingindo a camada de cemento, ora aprofundando-se na dentina. O reparo dessas áreas mostrou apenas tecido conjuntivo fibroso. No terço cervical, o ligamento periodontal se encontrava ainda com largura reduzida em relação ao normal, estando a raiz bastante próxima do osso alveolar e os vasos sangüíneos estavam com o lúmen reduzido e achatado. Os feixes de fibras mostravam-se comprimidos entre o dente e o osso, perdendo a sua disposição original. As fibras colágenas se apresentavam mais afiladas e em muitos locais sem definição dos feixes, produzindo imagem de tecido amorfo. Os fascículos de fibras colágenas e os fibroblastos encontravam-se desorganizados, perdendo sua configuração alongada. Discreto infiltrado inflamatório mononuclear apresentou-se mais concentrado e com predomínio de linfócitos. Nas áreas de diminuição da largura do espaço do ligamento periodontal, a superfície óssea alveolar estava irregular e socavada, com lacunas de Howship distribuídas em sua extensão, mostrando áreas de absorção que atingiam, de maneira uniforme, toda a parede alveolar. Esta região, contendo osteoclastos localizados no interior das lacunas e justapostos à superfície óssea caracterizaram áreas de absorção óssea frontal. As áreas endosteais não apresentaram modificações quanto à forma de absorção. Na crista óssea alveolar havia perda de organização e individualidade das 
fibras de Sharpey, com a crista tornando-se mais pontiaguda, exibindo áreas de absorção ativa. Na região apical as cavidades medulares ainda estavam amplas e com presença de muitos osteoclastos ativos (Figura 5, página 97).

No lado de tração evidenciou-se, provavelmente em decorrência do tipo de movimentação dentária promovida, o aumento do espaço periodontal, associado ao estiramento das fibras com os núcleos celulares orientados na direção do estiramento. A superfície radicular ainda possuía uma distribuição visível de cementoblastos. Os osteoblastos localizavam-se justapostos à superfície, em sua maioria, dispondo-se em paliçada, observavam-se ainda poucos espaços medulares com presença de discreto infiltrado inflamatório mononuclear (Figura 5, página 97).

\subsubsection{Animais DM submetidos à eutanásia 10 dias após ERM}

A partir deste período, mudanças topográficas significativas na raiz dentária foram observadas de forma mais intensa. De modo geral, no cemento radicular foram observados focos de absorção radicular mais intensas, geralmente adjacentes às áreas semi-hialinas, com grau de severidade variando desde pequenas e pouco profundas, às lesões profundas e extensas, associadas ou não a cementoclastos, que, quando presentes, eram evidentes e multinucleadas. Foi observada ainda, expressiva diminuição na largura do espaço do ligamento periodontal e, os feixes de fibras colágenas encontravam-se comprimidos, desorganizados sem orientação definida. Lateralmente, a esta área havia intensa proliferação celular e vascular. Os fibroblastos mostraram-se com mudanças relevantes na área de pressão, com perda do formato fusiforme característico, assumindo a forma ovalada e, quanto à disposição, foram encontrados comumente ao acaso. Em relação ao sistema circulatório, os vasos sangüíneos mostraram-se distribuídos, principalmente nas adjacências do osso alveolar, geralmente distendidos, hiperêmicos e com vários tamanhos e discreta hemorragia. Além da presença de discreto infiltrado inflamatório mononuclear contendo linfócitos, macrófagos e células polimorfonucleadas, tipo neutrófilos, foi observada pequena área de necrose na região apical do espaço periodontal. A superfície periosteal da cortical alveolar interna da região cervical apresentou-se recoberta por osteoclastos multinucleados ativos, dispostos em cadeia, caracterizando intensa atividade de absorção óssea frontal, deixando a superfície alveolar irregular, recortada, com várias lacunas de Howship, distribuídas em sua extensão. Na crista óssea alveolar, notaram-se perdas de organização e 
individualidade das fibras de Sharpey e a crista tornando-se pontiaguda, exibindo áreas de absorção ativa, com menor quantidade de massa óssea. Os osteoclastos, caracteristicamente multinucleados, também se localizavam no interior das cavidades medulares não apresentando mudanças quanto a absorção óssea (Figura 5, página 97).

No lado de tração as alterações morfológicas foram bem demarcadas, quando comparadas ao grupo ERM. Observou-se aumento na largura do espaço periodontal, feixes de fibras colágenas distendidas e fibroblastos com núcleos alongados. Vasos sanguíneos estavam presentes em maior número, dilatados, congestos e localizados de forma semelhante em todos os campos histológicos examinados; sempre entre as áreas de deposição de matriz óssea. Algumas áreas hemorrágicas foram observadas. $O$ processo de neo-formação óssea apresentou padrão diferente daquele observado no grupo ERM com deposição de matriz em espículas. Independente dessas diferenças, osteoblastos foram vistos alinhados, cobrindo a superifície óssea, associados à camada de osteóide. O tecido ósseo recém-mineralizado tinha aproximadamente, um terço da espessura do osso maduro e ambos apresentaram aspecto desorganizado com presença de numerosas linhas incrementais (Figura 5, página 97). 
Figura 5- Fotomicrografias do Grupo DM+ ERM, de 3, 7 e 10 dias após aplicação da força: $\mathrm{O}$ - tecido ósseo, LP - ligamento periodontal com fibras colágenas, vasos sanguíneos e células, $d$ - dente, *(preto) tecido inflamatório e *(branco) áreas hemorrágicas, seta - osteoclastos. Coloração de HE e Masson

GRUPO DM + ERM

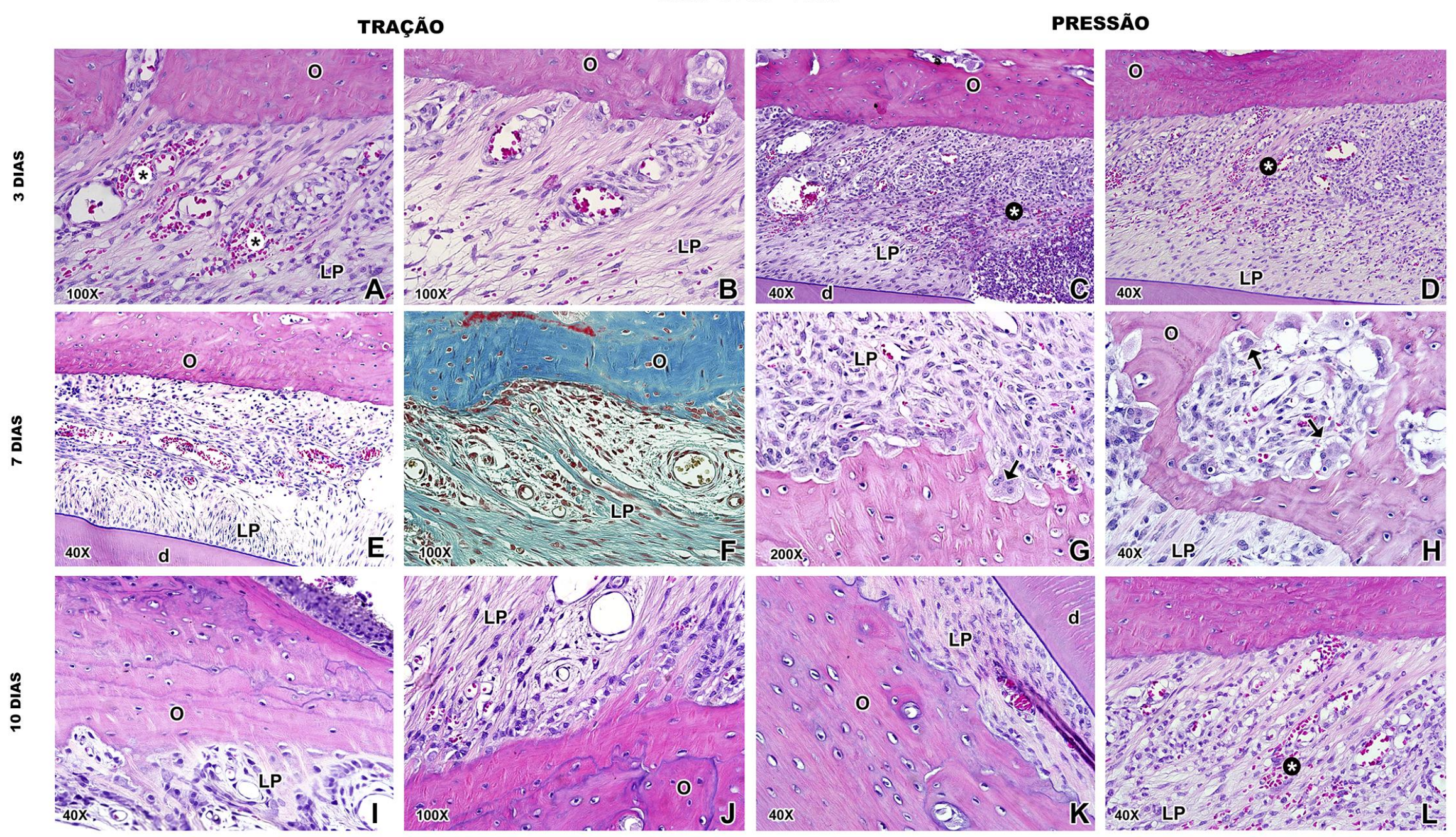





\subsubsection{Grupo Diabetes mellitus + Insulina + Expansão Rápida da Maxila (DM+INS+ERM)}

\subsubsection{Animais diabéticos tratados (INS), submetidos à eutanásia 3 dias após ERM}

No lado de pressão as àreas de absorção radicular estavam presentes ao longo da superfície radicluar. Tais áreas de absorção se localizavam principalmente no terço cervical das raízes e, nessas lesões não foram visualizados indícios de processo reparador. No ligamento periodontal comprimido encontraram-se feixes de fibras colágenas, com áreas apresentando desorganização tecidual e, as áreas hialinas estavam presentes. Ao longo do ligamento periodontal observaram-se vasos sangüíneos com a luz mais constrita (Figura 6, página 101).

No lado de tração, a superfície radicular apresentou-se preservada com a camada de cemento acelular uniforme e contínua em quase toda a sua etensão. As fibras colágenas estavam estiradas, com maior quantidade de capilares em relação ao grupo anterior, sendo que alguns estavam hiperêmicos e, áreas hemorrágicas também foram observadas (Figura 6, página 101).

\subsubsection{Animais diabéticos tratados (INS), submetidos à eutanásia 7 dias após ERM}

Econtrou-se áreas de hialinização, e indícios de atividade clástica em sua volta, bem como na superfície do cemento, e à distância nos espaços medulares. A superfície interna do osso alveolar, nas regiões de menor espessura do espaço periodontal, foi caracterizada pela presença de algumas áreas de absorção óssea frontal, porém com predomínio da absorção óssea solapante. A cortical interna do alvéolo, na região cervical, apresentou áreas típicas de zonas de pressão, com contorno irregular, de aspecto denteado, formando inúmeras lacunas de Howship, que alojam osteoclastos ativos, denotando absorção óssea frontal. O calibre dos vasos sangüíneos, próximo à superfície óssea estava aumentado. Observou-se discreto infiltrado inflamatório mononuclear contendo linfócitos, macrófagos, vasos sangüíneos congestos e discreta hemorragia. Os espaços medulares da região sob pressão apresentavam-se maiores que o normal e com intensa proliferação de osteoclastos ativos (Figura 6, página 101).

No lado de tração, observaram-se linhas de reversão em toda a extensão óssea, de forma mais pronunciada a partir do terço médio em direção ao ápice, 
demonstrando indícios de linhas de neoformação óssea, que delimitavam o osso alveolar maduro e o tecido osteóide, caracterizando o remodelamento da região. $\mathrm{Na}$ crista óssea alveolar, encontrou-se contorno caracteristicamente arredondado, ainda com focos de absorção bem como de linha de reversão, sendo nítidas as fibras de Sharpey (Figura 6, página 101).

\subsubsection{Animais diabéticos tratados (INS), submetidos à eutanásia 10 dias após ERM}

Após 10 dias da aplicação da força ortodôntica nos animais diabéticos tratados com insulina, as áreas de pressão e tração estavam bem definidas. Na zona de pressão, observou-se características semelhantes ao grupo DM+ERM. Na região apical, apesar da compressão do ligamento periodontal ser nítida, sua largura começou aumentar em função da absorção óssea frontal, predominantemente caracterizada pelos osteoclastos na superfície óssea e absorção solapante com osteoclastos nos espaços medulares. Observou-se atividade vascular aumentada nesta região, contendo vasos ora normais, ora comprimidos, e, alguns se apresentando congestos. Notou-se, ainda, discreta hemorragia pontual, em alguns casos. Persistiram poucas áreas de hialinização, porém agravou a profundidade das crateras nas superfícies radiculares que sofreram reabsorção, especialmente quando estavam associadas ao persistente infiltrado inflamatório. Nesta região, próxima aos vasos sangüíneos, algumas células semelhantes a macrófagos foram observadas, como também ocasionais células polimorfonucleadas e células gigantes multinucleadas. Estas últimas encontravam-se a certa distância da superfície óssea e radicular (Figura 6, página 101).

$\mathrm{Na}$ região de tração, observou-se um aumento na largura do espaço do ligamento periodontal, feixes de fibras colágenas perpendiculares, discretamente estiradas, oblíquas e paralelas entre si e bastante celularizadas com fibroblastos fusiformes, e alguns ovalados, distribuídos entre essas fibras. Vasos sanguíneos estavam presentes, dilatados, congestos e localizados de forma semelhante à observada no grupo diabético tratado (DM+INS). A neoformação óssea apresentouse com deposição de matriz em espículas. Osteoblastos estavam alinhados recobrindo a superfície óssea, associada à camada de osteóide. O osso alveolar apresentou aspecto desorganizado com numerosas linhas incrementais. Os cementoblastos estavam justapostos em toda extensão cementária e dispostos em paliçada (Figura 6, página 101). 
Figura 6- Fotomicrografias do Grupo DM+ INS+ ERM, de 3, 7 e 10 dias após aplicação da força: O - tecido ósseo, LP - ligamento periodontal com fibras colágenas, vasos sanguíneos e células, d - dente, seta - osteoclastos. Coloração de HE e Masson

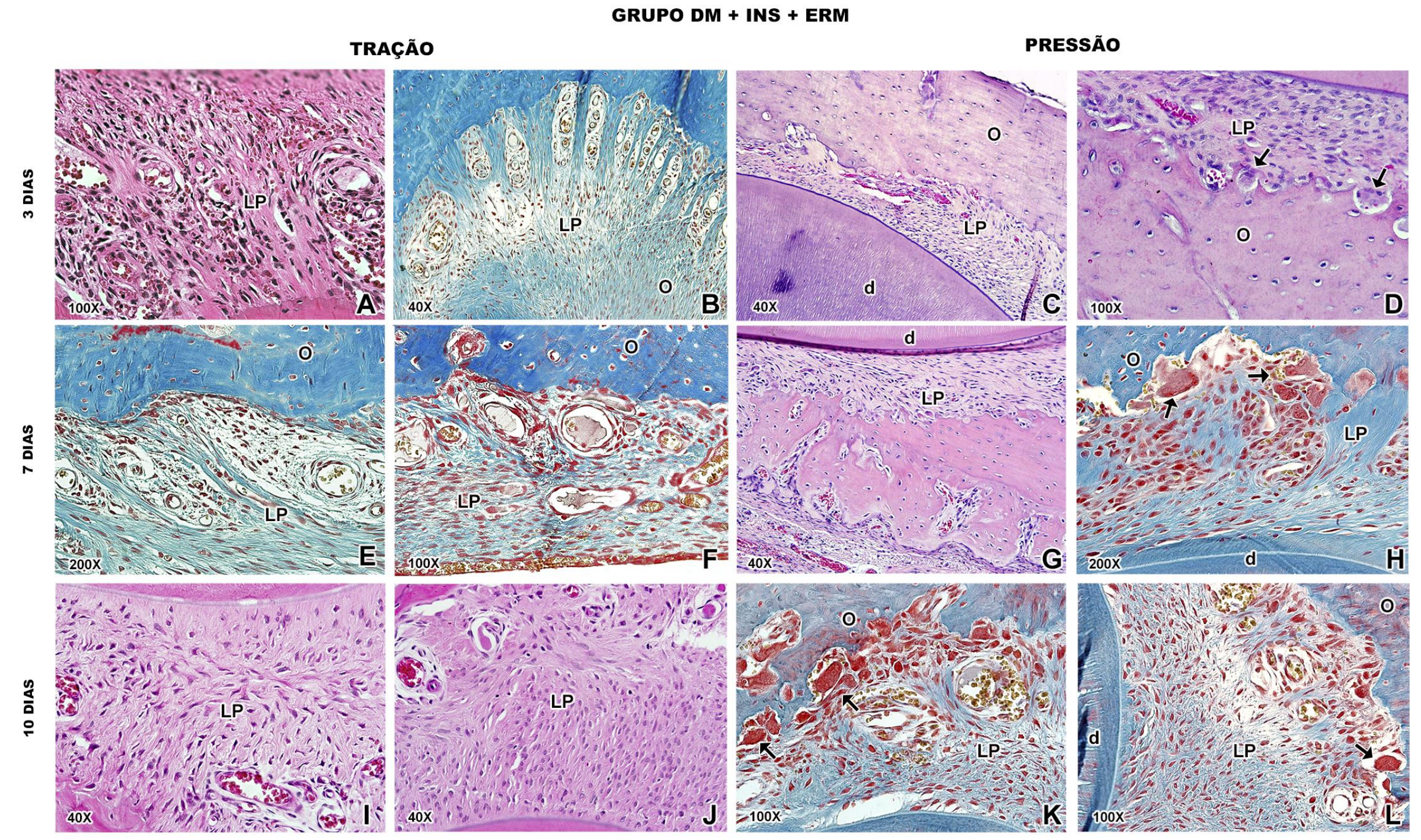





\subsection{Análise Imunoistoquímica}

As análises das reações imunoistoquímicas foram qualitativa e semi quantitativa em microscópio de luz. $\mathrm{Na}$ análise qualitativa foram consideradas a ausência e presença de marcações para as proteínas estudadas e a expressão das mesmas em diferentes tipos celulares. A avaliação semi quantitativa foi realizada a partir da atribuição de escores para as lâminas dos diferentes grupos e períodos experimentais. Foram avaliadas as imunomarcações para as proteínas TRAP; OPG e RANKL, representadas na figura 7, página 104. Nos grupos Controles (Controle, Diabetes Mellitus e Insulina) que não receberam aplicação de forças nos elementos dentários, apresentaram escore 0 (zero), não havendo diferença entre eles, portanto não foram considerados nos testes estatísticos aplicados.

Quadro 1- Escore utilizado para descrever a intensidade da presença de imunomarcação das proteínas analisadas

\begin{tabular}{|c|l|}
\hline Escore & \multicolumn{2}{|c|}{ Imunomarcação } \\
\hline 0 & Ausente $(0 \%)$ \\
\hline 1 & Discreta $(1 \%-30 \%)$ \\
\hline 2 & Moderada $(31 \%-60 \%)$ \\
\hline 3 & Intensa $(61 \%-100 \%)$ \\
\hline
\end{tabular}




\subsubsection{TRAP}

A técnica de imunorreatividade para TRAP foi específica para osteoclastos. Ao analisar as marcações para a proteína TRAP os resultados mostraram a imunomarcação de células semelhantes aos osteoclastos que estavam presentes ao redor do alvéolo e também no interior das cavidades medulares, no lado de pressão (Figura 10, página 107). Os grupos exprimentais (ERM, DM+ERM, DM+INS+ERM) mostraram marcação intensa de células multinucleadas por milímetro na região do periodonto durante o período experimental, sendo que no grupo não diabético (ERM) essa marcação foi maior no período inicial e nos grupos Diabetes Mellitus (DM+ERM) e Diabético tratado com insulina (DM+INS+ERM) a marcação foi mais intensa nos períodos posteriores, demonstrando que a reabsorção óssea ainda estava intensa nestes períodos $(p<0.05)$. (Figura 7 , página 104)

Figura 7- Análise semi-quantitativa da expressão de TRAP nos diferentes grupos e períodos analisados. Expressão da mediana, amplitude interquartil, valores máximos e mínimos dos escores de imunorreatividade para TRAP ( $p<0,05$; Kruskal-Wallis, teste de Dunn). Os dados correspondem a 10 dias de experimento. ${ }^{*} p<0,05 \%,{ }^{* *} p<0,01$
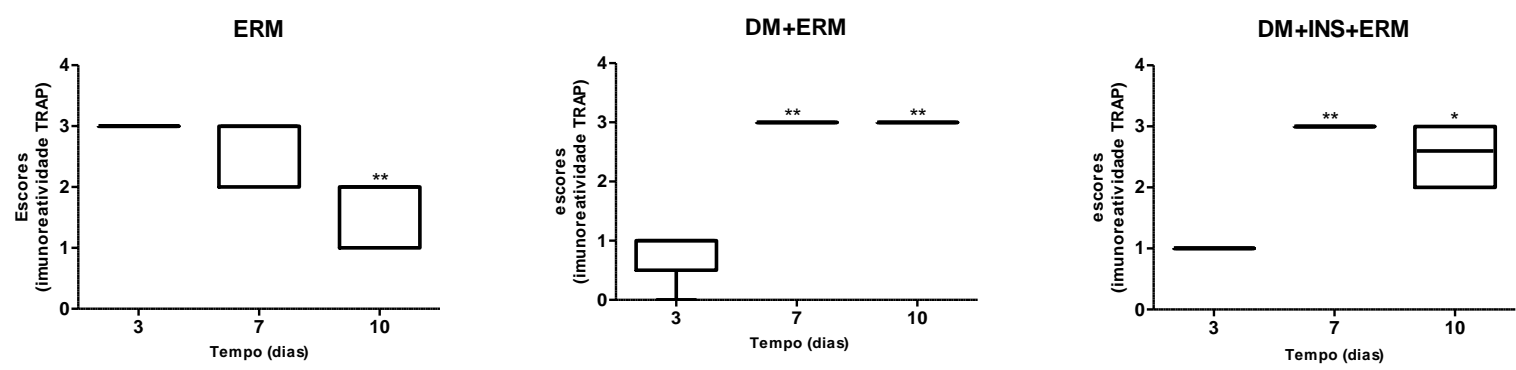


\subsubsection{RANKL}

Através de análise qualitativa, podemos sugerir que ao analisarmos as marcações positivas contra a proteína RANKL (Figura 10, página 107) foram visualizadas em células do tecido conjuntivo com morfologia semelhantes a osteoblastos dispostas ao redor do trabeculado ósseo em fase inicial de formação, e, também em alguns osteócitos aprisionados no tecido ósseo formado durante o processo de reparo alveolar, foram observados com marcação discreta para RANKL. Observamos também, a imunomarcação para o anticorpo contra RANKL nas células de revestimento do tecido ósseo. Estas células marcadas positivamente, apresentam morfologia semelhante a osteoblastos, que pela ausência de atividade metabólica, adquirem forma alongada e desempenham papel de revestimento do tecido ósseo (Figura 10, página 107). Para os grupos controles (C, DM e DM+INS) o escore 0 foi predominante, sem diferença estatística entre eles. Nos grupos experimentais, submetidos ERM o escore 3 prevaleceu, com diferença estatística quando comparado ao seu respectivo tempo experimental inicial $(p<0.05)$. Nos grupos diabéticos os escores 1 e 2 predominaram (Figura 8, página 105).

Figura 8- Análise semi-quantitativa da expressão de RANKL nos diferentes grupos e períodos analisados. Expressão da mediana, amplitude interquartil, valores máximos e mínimos dos escores de imunorreatividade para RANKL ( $p<0,05$; Kruskal-Wallis, teste de Dunn). Os dados correspondem a 10 dias de experimento. ${ }^{*} p<0,05 \%,{ }^{* *} p<0,01$

ERM

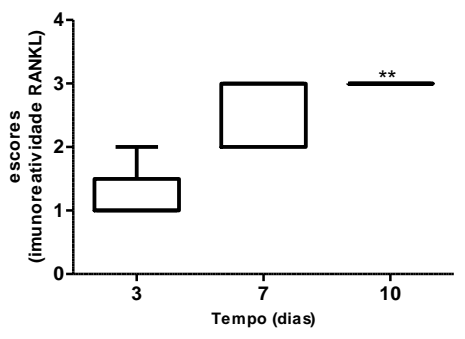

DM+ERM

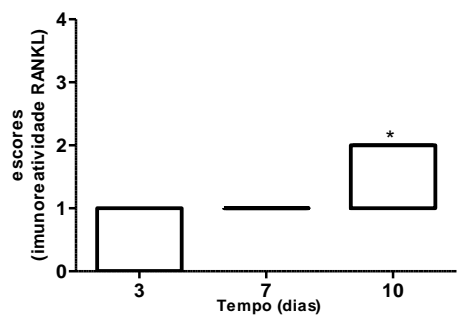

DM+INS+ERM

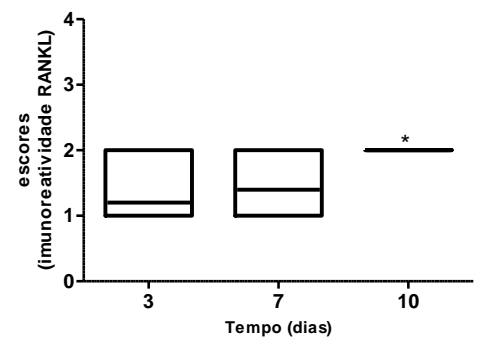




\subsubsection{OPG}

A Osteoprotegerina (OPG) foi visualizada em células do tecido conjuntivo, osteoblastos e osteócitos presentes ao redor e no interior do trabeculado ósseo neoformado (Figura 10, página 107).

Para os grupos controles (N, DM e DM+INS) prevaleceu o escore 1, sem diferença estatítica. Houve diferença estatítica entre os grupos controles e experimentais, sendo que aos 10 dias no grupo ERM prevaleceu o escore 3 e nos grupos DM+ERM e DM+INS+ERM prevaleceram os escores 1 e 2, respectivamente (Figura 9, página 106).

Figura 9- Análise semi-quantitativa da expressão de OPG nos diferentes grupos e períodos analisados. Expressão da mediana, amplitude interquartil, valores máximos e mínimos dos escores de imunorreatividade para OPG ( $p<0,05$; Kruskal-Wallis, teste de Dunn). Os dados correspondem a 10 dias de experimento. ${ }^{*} p<0,05 \%,{ }^{* *} p<0,01$

ERM

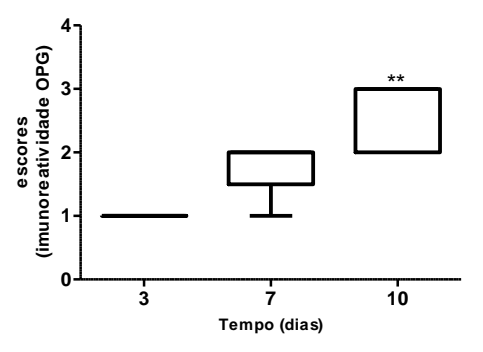

DM+ERM

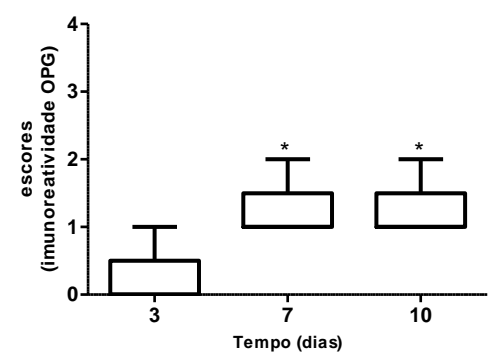

DM+INS+ERM

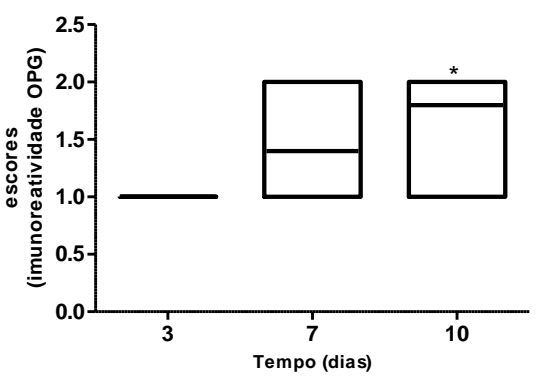


Figura 10- Gráficos mostrando os escores para TRAP (A), RANKL (B) e OPG (C) dos grupos analisados. Fotomicorgrafias mostrando a aparência histológica da imunomarcação para TRAP (A1, A2 e A3); RANKL (B1, B2 e B3) e OPG (C1, C2 e C3)

A

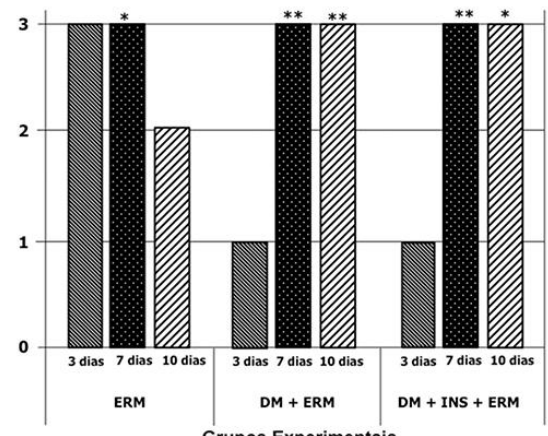

B

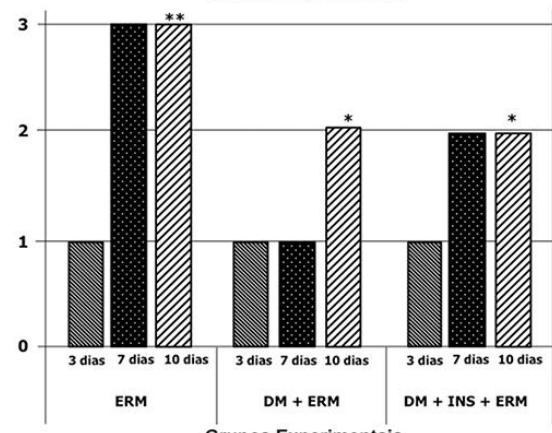

C

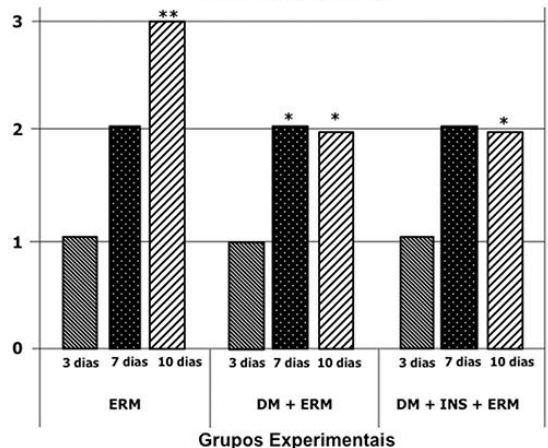

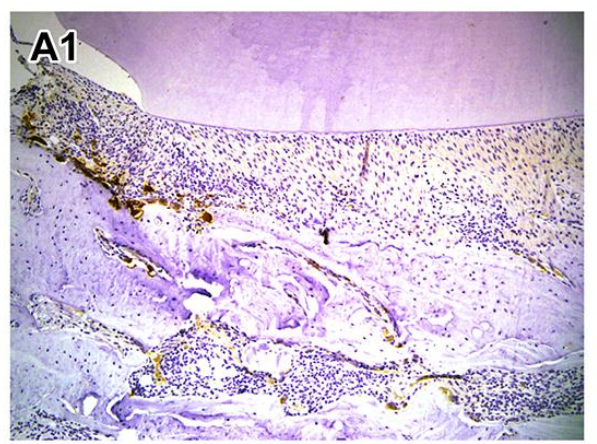
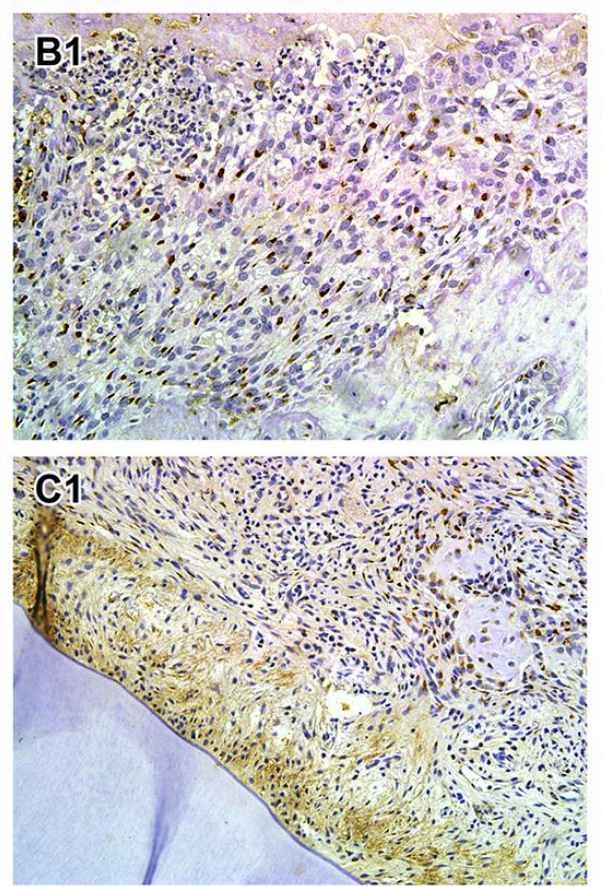
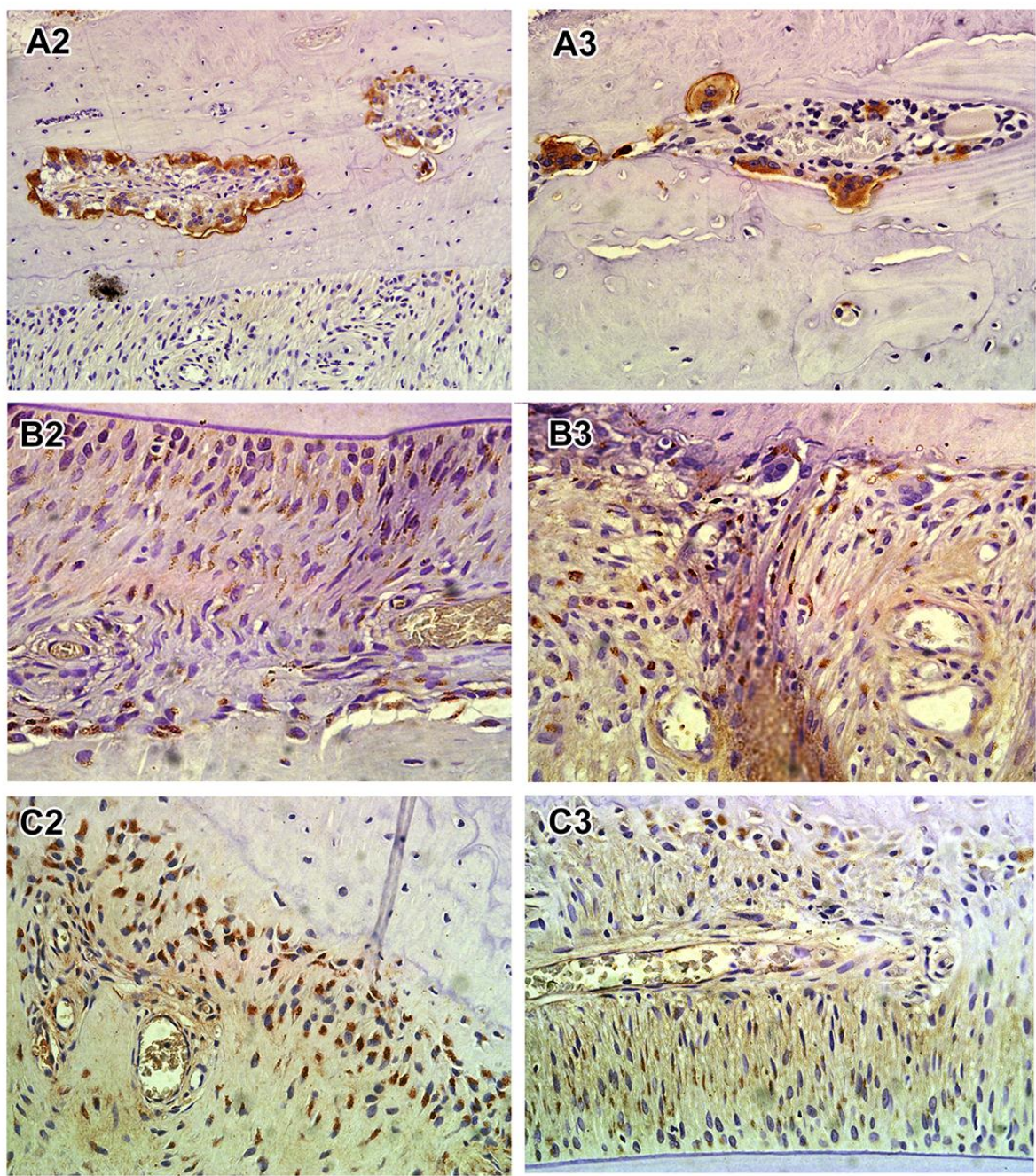

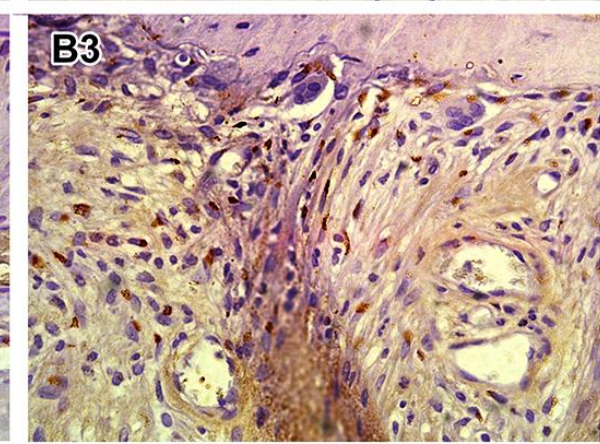

c3.

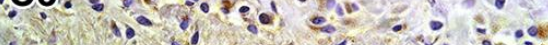

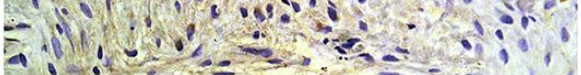

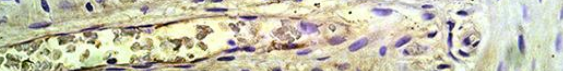

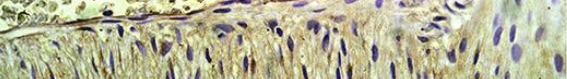

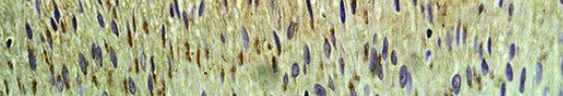

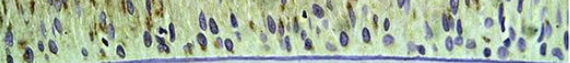



5. Discussão 



\section{DISCUSSÃO}

O Diabetes mellitus é uma doença de importância mundial, considerada um problema de saúde pública, caracterizada por anormalidades no metabolismo de carboidratos, proteínas, lipídios, água e eletrólitos (ADA, 2017; IDF, 2017) e em 2017 aproximadamente 451 milhões de pessoas (entre 18 e 99 anos) eram portadoras de diabetes em todo o mundo. A expectativa é que em 2045 serão 693 milhões de pessoas e praticamente metade das pessoas $(49,7 \%)$ que vivem com diabetes, não são diagnosticadas (Cho et al., 2018). Estimativas atuais presumem que os custos de saúde entre pessoas com diabetes são o dobro daqueles em pessoas sem diabetes, além de que, elas têm um risco aumentado de desenvolver vários problemas de saúde, redução da qualidade de vida e aumento da mortalidade. (Cho et al., 2018).

O diabetes mellitus tem importantes consequências negativas para a saúde, incluindo complicações microvasculares, macrovasculares e neuropáticas. É uma doença sistêmica que afeta quase todos os sistemas, desde a pele até o sistema renal (Abbassy et al., 2015).

Ismail et al. (2015) investigaram em sua revisão sistemática o estado de saúde bucal de crianças com DM1 e verificaram que elas apresentavam um estado de saúde oral geral mais fraco, com fluxo salivar reduzido, a capacidade de tamponamento alterada, pior saúde periodontal, com maior acúmulo de placa, quando comparadas com crianças saudáveis. Os dados também sugeriram que o diabetes mal controlado estava associado a pior estado de saúde bucal (Ismail et al., 2015). Durante as últimas décadas, pesquisadores exploraram o efeito do diabetes mellitus na saúde bucal e nos procedimentos odontológicos. A regeneração deficiente dos tecidos moles e a remodelação óssea retardada em pacientes com diabetes são complicações conhecidas durante a cirurgia oral (Al-Maskari et al., 2011). 
Tanto o DM1 quanto o DM2 estão associados ao comprometimento da saúde óssea. Em indivíduos com DM1 há um aumento de cerca de seis vezes no risco de fratura de quadril e um aumento de cerca de duas vezes no risco de fratura vertebral em comparação com indivíduos sem diabetes (Napoli et al., 2016). Apesar de a DM1 afetar negativamente a qualidade óssea, ela também é caracterizada por uma redução significativa na densidade mineral óssea (DMO), em particular no fêmur (Napoli et al., 2016). Consequentemente, a maior duração da doença e o pior controle da glicose estão associados a maior risco de fraturas (Palermo et al., 2017).

Devido à alta incidência do diabetes mellitus, elevado número de não diagnosticados, torna-se cada vez mais provável, que um paciente diabético, diagnosticado ou não, controlado ou não, procure o tratamento ortodôntico.

O tratamento ortodôntico é baseado no princípio de que uma aplicação prolongada de pressão no dente resultará em movimento, que é uma consequência da remodelação do osso circundante (Villarino, Lewicki, Ubios, 2011). A Ortodontia envolve a indução da movimentação dentária por aparelhos removíveis e fixos, com ou sem modificação do crescimento craniofacial, a fim de tratar o desalinhamento dos dentes e ou maxilares. Vários fatores sistêmicos têm sido observados para afetar adversamente o tratamento ortodôntico (Najeeb et al., 2017).

A ERM é um procedimento ortopédico que tem o objetivo de tratar a mordida cruzada posterior dental, esquelética, ou ambas (Betts et al., 1995; Carvalho et al., 2013; Kumar et al., 2013), e este estudo foi importante para avaliar como se comporta esta força ortopédica sobre o periodonto de sustentação dos dentes que ancoraram o dispositivo ortopédico, em ratos diabéticos tratados ou não com insulina.

A utilização de ratos Wistar como modelo de estudo, tem sido amplamente relatada na literatura (Maia et al., 2014; Gomes et al., 2017; Ferreira et al., 2018), além de minimizar fatores de confusão que podem haver em humanos. A escolha de machos foi para não haver interferência de hormônios do ciclo reprodutivo feminino. Quando aspectos das doenças não podem ser estudados diretamente em humanos, os animais de laboratórios são utilizados para o desenvolvimento das pesquisas. Dentre os diversos animais utilizados como modelo experimental do diabetes, o rato possui algumas vantagens, e a de especial interesse para esta pesquisa é a possibilidade da obtenção de alterações crônicas e degenerativas em pouco tempo, o que concorda com dados de Schellini et al. (1995). 
Existem diversas formas de estudar o diabetes em animais. Alguns autores fazem uso de animais geneticamente modificados (Plut et al., 2015), outros tem feito a indução experimental com aloxano (Maya et al., 2014; Gomes et al., 2017; Ferreira et al., 2018), outros pela estreptozotocina (Li et al., 2010; Braga et al., 2011; Villarino, Lewicki e Ubios, 2011, Zhang et al., 2011; Arita et al., 2016), dentre outras. No presente trabalho o diabetes mellitus foi induzido pela administração de dose única de estreptozotocina (Nascimento-Saba et al., 1997; Li et al., 2010; Villarino, Lewicki, Ubios, 2011), que trata-se de uma droga com alta especificidade e toxicidade menor quando comparada com o aloxano, também indutor do diabetes. Há evidência histológica de necrose das células beta do pâncreas, sete horas após a indução do diabetes com estreptozotocina. Após 24 horas esses sinais tornam-se ainda mais evidentes e o conteúdo de insulina pancreática é reduzido a $5 \%$ do normal (Junod, Lambert, Orci,1967).

Em nosso trabalho, os animais foram considerados diabéticos se o nível glicêmico estava acima de $300 \mathrm{mg} / \mathrm{dl}$, concordando com outros autores (Braga et al., 2011; Zhang et al., 2011) sendo que outros trabalhos consideraram os animais diabéticos, com níveis acima de 200mg/dl (Maya et al., 2014; Gomes et al., 2017). Plut et al. (2015) observaram que os animais geneticamente diabéticos apresentavam glicemia acima de 150mg. No presente experimento, todos os animais tiveram sua glicemia aferida antes da indução do diabetes, para eliminar animas que não fossem normoglicêmicos, e reavaliada $24 \mathrm{~h}$ após a injeção de STZ, quando verificou se os animais induzidos estavam realmente diabéticos (valor acima de $300 \mathrm{mg} / \mathrm{dl}$ ), e se os animais que receberam veículo tiveram alguma alteração do nível glicêmico. Os animais foram novamente avaliados quanto à glicemia no $2^{\circ}$ o dia, e os animais que por algum motivo tiveram reversão do quadro hiperglicêmico, ou do grupo não diabético que teve a glicemia alterada em alguma dessas aferições, foram descartados do experimento. Sabe-se que animais tratados com estreptozotocina retêm alguma capacidade de secretar insulina (Taborsky, 1989) e para eliminar a possibilidade de recuperação da glicemia normal, ao longo do experimento, somente foram considerados diabéticos com glicemia superior a $300 \mathrm{mg} / \mathrm{dl}$.

Diferentes tempos de "ação da hiperglicemia" nos animais foram relatados na literatura, antes que se realizasse o experimento. Alguns autores optaram por induzir o diabetes e apenas 2 semanas depois realizar o experimento, (Arita et 
al.,2016; Gomes et al., 2017), outros aguardaram 3 semanas (Braga et al., 2011) outros 6 semanas (Villarino, Lewicki e Ubios 2011; Maya et al., 2014; Plut et al., 2015) e outros por 8 semanas (Li et al., 2010; Zhang et al., 2011). Em nosso experimento optamos por induzir o diabetes e aguardar 4 semanas (28 dias) de ação do quadro hiperglicêmico, para depois iniciarmos os experimentos e tratamentos.

Nos animais não diabéticos, o nível glicêmico manteve-se baixo, como esperado. Já nos animais diabéticos não tratados com insulina (DM e DM+ERM), após a indução do DM, os níveis glicêmicos se mantiveram elevados (acima de $300 \mathrm{mg} / \mathrm{dl}$ ), e para os grupos DM+INS e DM+INS+ERM, mantiveram-se elevados até os 28 dias (acima de $300 \mathrm{mg} / \mathrm{dl}$ ), quando começaram a ser tratados com insulina. $O$ tratamento foi realizado com insulina NPH humana de ação intermediária, e foi aplicada 2 UI pela manhã e 4 UI a tarde, até a data da eutanásia (Freitas et al., 2007; Sabino-Silva et al., 2009; Okamoto et al., 2011). Uma vez que ratos tem hábitos noturnos de alimentação (Karam, 1997), a maior dose era dada no período da tarde. Embora tenha havido uma queda na glicemia dos animais tratados com insulina, não foi o suficiente para voltar à normoglicemia. Outros autores também fizeram tratamento dos animais induzidos ao diabetes com a insulina. Braga et al. (2011) não deixaram claro quando começaram o tratamento com a insulina, mas relataram conseguir um controle de 90-190mg/dl. Arita et al. (2016) e Villarino et al. (2011) optaram por iniciar o tratamento com insulina apenas $24 \mathrm{~h}$ após a aplicação de STZ, e relataram uma melhoria nos níveis glicêmicos. O primeiro estudo relatou que conseguiram uma melhoria da glicemia para menos de $180 \mathrm{mg} / \mathrm{dl}$, já o segundo estudo não relatou os valores obtidos. Estes autores simularam um quadro agudo de hiperglicemia nos animais e 24 horas após a indução do diabetes, já estabeleceram o tratamento com insulina. Nossos resultados glicêmicos nos animais tratados com insulina foram diferentes, pois os animais foram mantidos hiperglicêmicos por 28 dias, causado um quadro de cronicidade antes de instituir o tratamento com a insulina e provavelmente, teríamos resultados diferentes se utilizássemos a insulina por mais tempo (3, 7, ou 10 dias, de acordo com o grupo), que possibilitaria estabilizar os altos valores glicêmicos obtidos nos experimentos. Outra explicação pelo qual os animais diabéticos tratados com insulina não atingiram os valores de normalidade encontrados nos grupos C e ERM (não diabéticos), pode ser devido ao fato de que a administração de insulina efetuada não correspondeu a secreção fisiológica da mesma pelo pâncreas, talvez precisando ser uma dosagem maior. 
Ferreira et al., (2018) ao estudar o efeito da periodontia em ratos diabéticos submetidos ao uso de aparelho ortodôntico, detectaram que o DM teve efeitos deletérios na densidade óssea e perda óssea na região de furca, e estes efeitos foram maximizados quando associados à indução de periodontite, em animais sob movimentação ortodôntica. Alguns autores (Almadih et al., 2018, Sanz et al., 2018) sugerem que o a periodontite pode levar a um descontrole da glicemia em pacientes diabéticos. Embora em nosso experimento não tenhamos associado a indução de periodontite, pode ser que a glicemia dos animais do grupo $\mathrm{DM}+\mathrm{ERM}$ estaria ainda mais aumentada pós ERM em relação aos animais do grupo DM, pois o uso do dispositivo ortodôntico favorece ao acúmulo de placa bacteriana local, podendo levar a uma inflamação e possivelmente descontrolaria ainda mais a glicemia de tais animais.

Em relação ao peso corporal, os animais do grupo controle e do grupo ERM, desenvolveram-se normalmente, tiveram ganho de peso similar entre si, exceto nos dias iniciais que se seguiram à montagem do aparelho no grupo $\mathrm{ERM}$, que devido à dificuldade inicial de alimentação, verificou-se perda de peso logo após sua instalação, mas na última pesagem os animais mostraram sinal de recuperação, ganhando peso, confirmando que tanto a ERM quanto a mudança da consistência da ração (moída), não interferiu no peso e saúde destes animais (Sawada e Shimizu, 1996; Stuani, 2012).

Já os animais induzidos ao diabetes (DM, DM+INS, DM+ERM e DM+INS+ERM), tiveram uma redução do seu peso corporal observada aos 28 dias, uma das características avaliadas inclusive para auxiliar no diagnóstico do diabetes em humanos (WHO 2016). Nos grupos não tratados com insulina (DM e DM+ERM), estes valores continuaram baixos nos períodos de 3, 7 e 10 dias após a ERM. Estes resultados assemelham-se aos encontrados em outros estudos da literatura (Arita et al., 2016; Villarino, Lewicki e Ubios, 2011).

Por outro lado, nos animais diabéticos tratados com insulina após os 28 dias com hiperglicemia, o peso corporal ainda continuava baixo, semelhante aos animais diabéticos não tratados com insulina, mas com uma tendência ao aumento, que não atingiu o peso dos animais controles. Esse fato provavelmente ocorre, porque o tratamento com insulina que instituímos levou à compensação parcial do metabolismo da glicose, não restaurando a normoglicemia. No trabalho de Villarino et al. (2011), relataram que nos animais induzidos ao diabetes e tratados com 
insulina, o peso foi semelhante aos animais do grupo controle. Isso pode ser devido ao tratamento com insulina ter começado apenas 24 após a injeção de STZ, não havendo tempo da hiperglicemia afetar a perda de peso de modo notável.

A polidipsia faz parte de alguns dos sintomas que são observados para auxiliar no direcionamento do diagnóstico do diabetes junto aos exames laboratoriais (ADA, 2017; IDF, 2017; Cho et al., 2018). No período inicial, todos os animais tiveram um consumo hídrico diário semelhante, que mudou no dia posterior à injeção de STZ e já tiveram seu consumo hídrico aumentado. Nos animais que receberem injeção intraperitoneal do tampão citrato (C, ERM), não houve alteração na quantidade de consumo hídrico, que permaneceu baixo, e nós consideramos 0 padrão de normalidade para a ingestão de água. Já nos grupos que receberam tratamento com insulina pós 28 dias de hiperglicemia, a ingestão de água foi elevada, semelhante aos grupos diabético não tratados. Possivelmente isso se deve ao fato de a insulina aplicada não ter conseguido normalizar a glicemia de tais animais. Schellini et al. (1995), em experimento com animais, não constataram diferença na média de ingestão hídrica dos grupos diabéticos e diabéticos tratados, concordando com os achados do presente estudo.

Em resumo, os animais que receberam a indução do diabetes pela STZ (DM, DM+INS, DM+INS, DM+INS+ERM), tiveram perda de peso, aumento do consumo hídrico e principalmente o quadro de hiperglicemia (maior do que $200 \mathrm{mg} / \mathrm{dl}$ ), sinais clínicos utilizados para confirmar o diagnóstico do DM (SBD, ADA, WHO, CHO 2018), e validar que estes animais estavam com a doença sistêmica diabetes mellitus instalada, e as alterações de normalidade que obtivemos no periodonto de sustentação, provavelmente foi em decorrência dela.

Em relação à descrição histológica, o grupo controle foi utilizado como padrão de normalidade. Como os grupos controle, DM e DM+INS não receberam aplicação de forças ortopédicas, tanto o lado mesial quanto o distal, apresentavamse de modo semelhante. Além disso, entre estes 3 grupos (C, DM e DM+INS), não observamos variação histológica nos 3 tempos estudados (3, 7 e 10 dias pós início experimental), sendo assim, abordamos estes 3 períodos em um resultado "único" para cada um destes grupos.

Os grupos DM e DM+INS foram semelhantes entre si, possivelmente pelo longo tempo de ação da hiperglicemia (28 dias) antes de iniciar o tratamento com insulina, ou devido à dose de insulina aplicada ter sido baixa, ou porque não houve 
tempo suficiente para haver reversão do quadro histológico. Já os dados dos grupos DM e DM+INS, foram distintos em relação ao grupo controle. Os grupos diabéticos apresentaram o contorno interno do osso alveolar levemente irregular em relação ao grupo C. Já o ligamento periodontal, no grupo C era uniforme, com abundância de fibras ordenadas e várias células presentes. O trabalho de Zhang et al. (2011), teve resultados histológicos semelhantes ao nosso no grupo controle, em que tanto o colágeno quanto os capilares, estavam normalmente distribuídos e orientados no ligamento periodontal. Já em nossos grupos DM e DM+INS, o LP apresentou duas regiões distintas, uma próxima ao cemento, caracterizada pela leve perda da orientação das fibras colágenas, presença de muitas células com fibroblastos jovens e núcleos arredondados e volumosos; e a camada voltada para o osso alveolar, com maior vascularização e sinais de hiperemia, menor número de fibroblastos e estes eram alongados ou estrelados, em meio à maior quantidade de fibras colágenas, embora estas apresentassem perda de orientação e mais delgadas.

Nos grupos Diabéticos notou-se alterações na morfologia do ligamento periodontal e osso alveolar. Sabendo-se que a insulina é regulador fisiológico da manutenção da síntese de colágeno tipo I (Johnson, 1992; Nevis, Karimbux, Weber, 1998) e uma vez que esse é o componente principal do ligamento periodontal e da matriz orgânica do osso alveolar, as alterações metabólicas, associadas ao diabetes mellitus, podem afetar a integridade e a resistência das fibras do ligamento periodontal e osso alveolar e a conexão entre os mesmos (Johnson, 1992), razão pela qual maior perda óssea é verificada em pacientes diabéticos, quando comparados aos controles, durante avaliação periodontal (Cianciola, Park, Bruck, 1982; Emrich, Shlossman, Genco, 1991).

Nos Grupos Diabéticos e Diabéticos tratados, duas áreas distintas foram observadas no ligamento periodontal. A primeira camada, próxima ao cemento, e a segunda camada, voltada para o osso alveolar, com maior quantidade de fibras e feixes vásculo-nervoso. Diferenças no arranjo dos fibroblastos no ligamento periodontal, em ratos diabéticos, haviam sido descritas por Sasaki, Ramamurthy e Yu (1992). Nesses grupos, a superfície do osso alveolar, voltada para o ligamento, apresentou contorno irregular. As linhas incrementais estavam em maior número e sem orientação definida.

Alterações específicas na formação e absorção óssea tem sido associadas ao diabetes mellitus (Nevis, Karimbux, Weber, 1998). Diminuição na síntese de 
matriz osteóide (Goodman e Hori 1984), redução no número de osteoclastos (Hough, Avioli, Bergfeld,1981) e osteoblastos (Verhaeghe, Herck, Visser, 1990), alterações estruturais e menor número de proteoglicanas, compondo a matriz óssea (Weiss, Gorn, Nimni, 1981), embora tenham observado quantidades semelhantes de osso neoformado em torno de implantes, relatam a aparência imatura e desorganizada desse osso.

No grupo ERM, entre os incisivos centrais superiores, foi colocado o dispositivo ortodôntico que mantinha a sutura palatina mediana aberta, causando uma área de tração (face mesial), e pressão (distal), no ligamento periodontal dos incisivos superiores, maior nos terços cervical e médio. A escolha dos períodos avaliados neste estudo foi feita a partir de estudos prévios, (Zhang et al.,2011, Stuani, 2012; Arnez, 2014) que observaram aos 3 e 7 dias pós ERM uma reação tecidual intensa e aos 10 dias já uma tendência ao retorno da normalidade.

Nos animais do grupo ERM, observou-se na gengiva marginal livre dos incisivos centrais um processo inflamatório superficial, que pode ser devido ao dispositivo ortodôntico recoberto por resina ter se tornado uma barreira física, onde restos alimentares podem parar. No grupo ERM, no lado de pressão, aos 3 dias, houve uma redução do ligamento periodontal em relação ao controle, com compressão de vasos, células, e áreas de hialinização, com predomínio de infiltrado inflamatório. Na superfície da raiz, havia poucos cementoblastos destruídos e poucos osteoblastos. No ápice radicular, havia absorção cemento-dentinária. $\mathrm{Na}$ superfície alveolar adjacente à área de hialinização, células clásticas promoviam reabsorção à distância. Aspectos histológicos semelhantes aos relatados em diferentes pesquisas (Reitan 1967, Reitan e Rygh 1994, Rygh, Bowling, Sorsa, 1999).

Nos grupos DM+ERM e DM+INS+ERM, as zonas de tração e pressão também foram facilmente distinguidas. $\mathrm{Na}$ área de tração, observou-se aumento na largura do espaço do ligamento periodontal, feixes de fibras distendidas, mas os fibroblastos apresentavam núcleos menos alongados, quando comparados com os do grupo ERM. Já no trabalho de Zhang et al. (2011), no grupo ortodôntico as alterações de capilares comprimidos e colágeno irregular se mantiveram até os 7 dias, e ao 10 dias já apresntou sinais de normalidade, enquanto no grupo DM com ortodontia, capilares distendidos e as fibras colágenas permaneceram anormalmente orientadas até o final do experimento (14 dias). 
Observamos também que nos grupos DM+ERM e DM+INS+ERM, os feixes vásculo nervosos estavam presentes em maior número. O processo de neoformação óssea apresentou deposição de matriz em espículas. O tecido ósseo recém mineralizado apresentava aspecto desorganizado com presença de numerosas linhas incrementais. Na área de pressão, a superfície óssea mostrou-se irregular com poucas lacunas de Howship e osteoclastos em seu interior. A absorção óssea foi frontal em todas as laminas examinadas. As proximidades das áreas de absorção estavam livres de osteoblastos. Achados histológicos realizados por Li et al. (2010), em períodos semelhantes aos do nosso estudo, também evidenciaram que a força ortodôntica estimulou a osteoclastogênese e a formação de lacunas de Howship, tanto no grupo normal quanto no diabético. O número de osteoclasto aumentou em ambos os grupos até seu pico aos 7 dias, mas enquanto aos 14 dias o grupo normal teve uma grande redução, no grupo DM houve uma pequena redução no número de osteoclastos. Em nossos achados também observamos uma redução na quantidade de osteoclastos no grupo ERM ao final dos 10 dias de experimento.

Já no experimento de Gomes et al., (2017), avaliaram histologicamente os períodos de 7, 14 e 21 dias. No grupo DM com aparelho ortodôntico, aos 7 dias, observaram perda óssea alveolar, vasos sanguíneos congestionados, e intenso infiltrado de células inflamatórias mononucleares, enquanto que nos não diabéticos, havia uma perda óssea discreta e leve infiltrado inflamatório. Aos 14 dias, agravouse a reabsorção óssea e aumentou o infiltrado inflamatório, tanto no grupo diabético quanto no normal, com aparelho ortodôntico, o que diferiu de nossos resultados, pois aos 10 dias vimos uma tendência a recuperação no grupo ERM. Este resultados distintos podem ser devido a tipos diferentes de aparelhos e forças utilizados nos trabalhos, gerando um resposta tecidual diferente.

Outros estudos também avaliaram o periodonto de sustentação em animais diabéticos com animais saudáveis, submetidos ao tratamento ortodôntico, e verificou-se uma maior reabsorção óssea e remodelação óssea diminuída em animais diabéticos (Li et al., 2010, Braga et al., 2011; Villarino, Lewicki e Ubios, 2011; Zhang et al., 2011; Plut et al., 2015; Arita et al., 2016). Nossos resultados foram semelhantes aos destes pesquisadores.

Os resultados dessa pesquisa diferem dos encontrados por Souza (2001). Embora nas duas pesquisas o tempo de aplicação da força tenha sido semelhante, o período durante o qual os animais ficaram diabéticos antes da instalação do 
aparelho e início da movimentação ortodôntica foi de 28 dias no presente experimento. Souza (2001) iniciou a movimentação logo após a constatação do diabetes e, logo após o sacrifício observou presença de células inflamatórias e absorção óssea mais acentuada no grupo diabético.

As alterações histológicas verificadas nesse estudo mostraram-se mais marcantes nos grupos Diabéticos. As características observadas nos grupos Diabéticos tratados com Insulina mostraram padrão intermediário, não tendo atingido as características de normalidade do grupo controle. Resultado discordante de trabalhos que afirmam que o trabalho com insulina tenderia a reverter o quadro de alterações (Goodman e Hori 1984; Shyng, Devlin, Sloan 2001; Braga et al., 2011; Villarino, Lewicki, Ubios, 2011, Sun et al., 2017).

Zhang et al., (2011) observaram que após o estresse ortodôntico em animais normoglicêmicos, o Colágeno tipo I teve uma pequena queda até o terceiro dia, quando começou a aumentar gradualmente até atingir o nível do controle, enquanto o MMP-1 teve um aumento até o terceiro dia, quando retornou gradualmente aos níveis de controle no dia 14. No entanto, os níveis de Col - I em ratos induzidos ao diabetes permaneceram mais baixos do início ao final do estudo e os níveis de MMP-1 permaneceram estáveis durante os primeiros 3 dias e após o sétimo dia, aumentaram acentuadamente e permaneceram elevados até o dia 14. Sabendo-se que a MMP-1 causa degradação das fibras de colágeno e outros componentes da matriz extracelular (Kubota et al., 1996), este estudo pode contribuir e corroborar com nossos resultados, pois os animais hiperglicêmicos demonstraram iniciar tardiamente o reparo do periodonto e osso em relação a animais saudáveis.

Reações imunoistoquímicas foram realizadas para evidenciar as proteínas TRAP, RANKL, e OPG. Para estas reações foram realizadas análise qualitativa e semi quantitativa através da atribuição de scores para a intensidade da expressão das proteínas analisadas, sendo escore 0 (ausente), escore 1 (discreta marcação), escore 2 (moderada marcação) e escore 3 (intensa marcação). A alteração sistêmica do diabetes mellitus promove aumento na taxa de reabsorção óssea, pois a imunomarcação para a proteína TRAP foi alta aos 10 dias e, redução significativa na taxa de formação e maturação óssea, pois a imunomarcação para as proteínas RANKL e OPG aos 10 dias foi menor. Isto atrasa o processo de reparo alveolar e reduz as respostas sinalizadoras das células envolvidas no processo de reparo alveolar, mostrado pela menor imunomarcação para as proteínas formadoras de 
osso avaliadas neste projeto. Nosso resultado em relação ao TRAP, concordou com com os de Hie et al. (2007), que após 1 semana da indução do diabetes com STZ em ratos, obtiveram aumento na expressão gênica de TRAP e da catepsina $\mathrm{K}$ em osteoclastos, e obtiveram também uma redução dos níveis de osteocalcina em osteoblastos e isso resultou em aumento da atividade de reabsorção óssea e uma diminuição da formação óssea.

No grupo que teve apenas a ERM os resultados mostraram que qualitativamente ocorre um balanço na expressão das proteínas que caracterizam reabsorção e neoformação óssea nos diferentes períodos estudados, onde aos 10 dias ocorre maior expressão de OPG e RANKL e menor expressão de TRAP. Com relação à proteína TRAP, observou-se que ela foi expressa em osteoclastos diferenciados e às proteínas OPG e RANKL, observou-se que elas apresentavam-se expressas nas células da linhagem osteoblástica e células do tecido conjuntivo, como os fibroblastos, de forma similar, sendo que aos 10 dias foi o período de maior expressão destas proteínas.

O GRUPO ERM apresentou o maior turnover ósseo representado pelas colocalizações de TRAP, OPG e RANKL observada nas células, durante os períodos experimentais. Aos 10 dias apresentou intensa atividade celular representada pela alta imunorreatividade à OPG e RANKL. Nos GRUPO DM+ERM e DM+INS+ERM apresentaram menor turnover ósseo.

Braga et al., (2011) em seu experimento com ratos induzidos ao diabetes por STZ, avaliaram o número de TRAP-positivo (osteclastos) e observaram que todos os grupos que foram submetidos ao tratamento ortodôntico (diabéticos ou não), após 6 dias da sua instalação, tiveram um aumento na quantidade de osteoclastos, e esta quantidade foi estatisicamente maior no grupo diabetes + ortodontia, do que no grupo diabetes+ortodontia+insulina, do que no grupo ortodontia, e estes dois últimos tinham quantidade semelhante entre si. Aos 12 dias, a expressão de TRAP positivo dobrou para todos os grupos com ortodontia, e continuou significante a diferença do grupo diabetes+ortodontia em relação aos outros dois grupos com valores semelhantes (grupo ortodontia+diabetes+insulina e grupo ortodontia). Estes resultados foram semelhantes ao nosso, em que o teve maior marcação para o TRAP no grupo DM+ERM, por volta dos 10 dias. Já em nossos resultados, o grupo DM+ERM+INS teve resultado diferente ao do grupo ERM, pelos possíveis motivos já mencionados. 
No estudo de Gomes et al., (2017), avaliaram pela imunohistoquímica a expressão de OPG e RANKL, e observaram que no período de 14 dias, houve redução significativa da expressão de OPG do grupo não diabético com aparelho em relação ao diabético com aparelho. Em nosso estudo avaliamos o período de 10 dias, que apresentava também baixa expressão de OPG, embora seja difícil estabelecer uma comparação, pois em ratos as mudanças ocorrem muito depressa, além de que, os nossos resultados foram expressos em scores enquanto eles quantificaram.

O receptor ativador do Fator Nuclear Kappa B (RANK), o ligante de RANK (RANKL) e a osteoprotegerina (OPG) fornecem a base celular e molecular para o cross-talk entre osteoblasto e osteoclasto, células cruciais no processo de remodelação óssea (Horowitz et al., 2001). O RANK, que pertence à superfamília do fator de necrose tumoral (TNF), está presente na superfície dos precursores de osteoclastos e é ativado pelo RANKL. Esta interação induz a diferenciação de monócitos em osteoclastos, assim iniciando o processo de reabsorção. O sistema RANK/RANKL/OPG controlam o processo de remodelação e fazem parte do metabolismo ósseo. O RANKL é um agonista que regula aspectos importantes dos osteoclastos como diferenciação, fusão, sobrevivência, ativação e apoptose. Uma vez que a ativação de RANK por RANKL inicia o processo de reabsorção óssea, esse mediador solúvel pode ser considerado um marcador de reabsorção óssea. Por outro lado, a OPG também membro da superfamília do TNF, é um receptor solúvel secretado, que é um antagonista do RANKL, uma vez que interrompe esta ativação pela ligação direta do RANKL, evitando o processo de reabsorção óssea, isto é, a OPG regula negativamente o processo de osteoclastogênese (Horowitz et al., 2001).

Autores sugerem que a hiperglicemia crônica desempenham um papel central na fragilidade óssea e os produtos finais da Glicosilação acançada agem em ação coordenada, inibindo a diferenciação osteoblástica e a formação óssea diretamente e indiretamente, aumentando a expressão da esclerostina nos osteócitos, bem como contribuir para uma baixa taxa óssea de remodelação diminuindo o balanço RANKL / OPG em osteoblastos e osteócitos (Palermo et al., 2017, Kanazawa e Sugimoto, 2018).

Nathan et al., (2014) fazem parte do DCCT (Diabetes Control and Complications Trial) e do EDIC (Epidemiology of Diabetes Interventions and Complications Study). O primeiro é um estudo clínico randomizado (1982-1993), 
multicêntrico, com 1.441 indivíduos com DM1, cujo objetivo era comparar a terapia intensiva, (níveis de glicemia tão próximos do intervalo não diabético), com a terapia convencional (controle glicêmico assintomático) e o segundo (1994-presente), um estudo observacional da coorte do DCCT. Foram projetados para determinar se as complicações que afetam as pessoas com diabetes tipo 1 poderiam ser melhoradas pela terapia glicêmica intensiva. Coletaram dados sobre a história médica, exames de saúde e avaliações laboratoriais e outras avaliações para doença microvascular e macrovascular. O controle glicêmico intensivo reduziu nestes pacientes o risco de retinopatia, nefropatia e neuropatia em $76 \%, 50 \%$ e $60 \%$, respectivamente. Com o tratamento intensivo do diabetes, observaram um atraso no início e retardo da progressão da retinopatia diabética (Nathan et al., 2014). Os resultados desta grande coorte vem juntamente com nossos dados demonstrar que um "controle relativo" da glicemia, não é o suficiente para trazer o paciente à normalidade, e que é necessário e mais salutar, que o paciente faça um controle glicêmico bem monitorado.

Como para a maioria dos pacientes com diabetes tipo 1, as estratégias atuais para otimizar o controle glicêmico são insuficientes para prevenir ou retardar completamente o desenvolvimento de complicações neuropáticas (Nathan et al., 2014), é necessário que mais pesquisas sejam feitas, para que saibamos os pormenores da doença diabetes mellitus e suas complicações clínicas, pois se mesmo muito bem controlada, haverá sequelas, e que uma grande parcela da sociedade possui esta doença, precisamos aprender a lidar tais pacientes.

Os resultados apresentados e discutidos nesta pesquisa mostram que 0 tratamento ortodôntico em pacientes diabéticos deve ser realizado com ressalvas. A força aplicada aos dentes não mostrou diferença clinicamente significativa quando da comparação dos grupos. No entanto, alterações histológicas foram verificadas, o que indicam uma resposta alterada quando na presença do diabetes não controlado. Sendo assim, a preocupação ao se deparar com paciente diabético, deve ser quanto à importância de um controle glicêmico rigoroso por parte do paciente. 

6. Conclusão 



\section{CONCLUSÃO}

A partir do presente estudo, pode-se concluir que:

1. A ERM resultou em intensa remodelação do periodonto de sustentação dos incisivos superiores dos ratos, caracterizada por tecido desorganizado com intensas áreas inflamatórias, hemorrágicas e reabsortivas em períodos iniciais, seguida por tecido ósseo neo-formado bastante celularizado com numerosos vasos sanguíneos, fibroblastos e osteoblastos em fase tardia de reparo. O Diabetes mellitus tipo I exacerbou e prolongou os eventos inflamatórios após a ERM, com presença de tecido desorganizado e atividade osteoclástica persistente em períodos mais tardios de reparo.

Nos animais com diabetes mellitus, não submetidos à ERM, observou-se histologicamente um atraso na remodelação óssea fisiológica.

2. Ocorreu estímulo à osteoclastogênese nos grupos submetidos à ERM, com menor magnitude nos ratos com diabetes. Os marcadores de osteogênese foram estimulados nos animais submetidos à ERM, durante todo o tempo avaliado. A associação entre os dois fatores de estudo, o diabetes e a ERM, contribuiu para o atraso no reparo ósseo. 

Referências 



\section{REFERÊNCIAS}

Abbassy MA, Watari I, Bakry AS, Hamba H, Hassan AH, Tagami J, Ono T Diabetes detrimental effects on enamel and dentine formation. J Dent. 2015 May; 43(5):589-96.

Abbassy MA, Watari I, Soma K. Effect of experimental diabetes on craniofacial growth in rats. Arch Oral Biol. 2008 Sep; 53(9):819-25.

Almadih A, Al-Zayer M, Dabel S, Alkhalaf A, Mayyad AA, Bardisi W, Alshammari S, and Alsihati Z. Orthodontic Treatment Consideration in Diabetic Patients. J Clin Med Res. 2018 Feb; 10(2):77-81.

Al-Maskari AY, Al-Maskari MY, Al-Sudairy S. Oral Manifestations and Complications of Diabetes Mellitus: A review. Sultan Qaboos Univ Med J. 2011 May; 11(2):179-86.

American Diabetes Association. (ADA) Standards of Medical Care in Diabetes - 2011. Diabetes Care. 2011; 34 (Suppl1):S11-S61.

American Diabetes Association®- Statistics about diabetes. [Online]. Available: http://www.diabetes.org/diabetes-basics/statistics/?referrer=https://www.google.com.eg/.

Accessed: 06-Apr-2017.

Arita K, Hotokezaka H, Hashimoto M, Nakano-Tajima T, Kurohama T, Kondo T, Darendeliler MA, Yoshida N. Effects of diabetes on tooth movement and root resorption after orthodontic force application in rats. Orthod Craniofac Res. 2016 May; 19(2):83-92.

Arnez MFM. Diabetes Mellitus altera a sinalização osteogênica e atrasa o processo reparo ósseo após a Expanão Rápida da Maxila [doutorado]. Ribeirão Preto: Faculdade de Odontologia de Ribeirão Preto da Universidade de São Paulo; 2014.

Arnez MFM, Ribeiro LSN, Barretto GD, Monteiro PM, Ervolino E, Stuani MBS. RANK/RANKL/OPG Expression in Rapid Maxillary Expansion. Braz. Dent. J. [Internet]. 2017 June [cited 2018 July 29] ; 28( 3 ): 296-300. Available from: http://www.scielo.br/scielo.php?script=sci_arttext\&pid=S0103-64402017000300296\&lng=en. http://dx.doi.org/10.1590/0103-6440201601116.

Betts NJ, Vanarsdall RL, Barber HD, Higgins-Barber K, Fonseca RJ. Diagnosis and treatment of transverse maxillary deficiency. Int $\mathrm{J}$ Adult Orthodon Orthognath Surg. $1995 ; 10(2): 75-96$.

Blondel $\mathrm{O}$, Bailbe $\mathrm{D}$, Portha B. Relation of insulin deficiency to impaired insulin action in NIDDM adult rats given streptozotocin as neonates. Diabetes. 1989; 38:610-617.

Boyle WJ, Simonet WS, Lacey DL. Osteoclast differentiation and activation. Nature 15: 33742, 2003. 
Braga SM, Taddei SR, Andrade I Jr, Queiroz-Junior CM, Garlet GP, Repeke CE, Teixeira MM. et al. Effect of diabetes on orthodontic tooth movement in a mouse model. Eur $\mathrm{J}$ Oral Sci. 2011;119(1):7-14.

Carvalho ACP, Okamoto T. Reparações do Alvéolo Dental. In Cirurgia Bucal. Fundamentos Experimentais aplicados à Clínica. São Paulo: Panamericana. 1987.

Carvalho AC, Paiva SM, Viegas CM, Scarpelli AC, et al. Impact of Malocclusion on Oral Health-Related Quality of Life among Brazilian Preschool Children: a Population-Based Study. Braz. Dent. J. [Internet]. 2013 Dec [cited 2018 July 29; 24 (6):655-661.

Cianciola LJ, Park BH, Bruck E. Prevalence of periodontal disease in insulin-dependent diabetes mellitus (juvenile diabetes). JADA. May 1982; 104(5):653-60.

Cho NH, Shaw JE, Karuranga S, Huang Y, da Rocha Fernandes JD, Ohlrogge AW, Malanda B. IDF Diabetes Atlas: Global estimates of diabetes prevalence for 2017 and projections for 2045. Diabetes Res Clin Pract. 2018 Apr; 138:271-281. Epub 2018 Feb 26. J Clin Med Res. 2018 Feb;10(2):77-81.

Consolaro A. Reabsorçoes dentárias nas especialidades clínicas. 2ª Ed., Maringá, PR, Dental Press. 2005; 372 p. 332p. 355p.

Danaei G, Finucane MM, Lu Y, Singh GM, Cowan MJ, Paciorek CJ, et al. National, regional, and global trends in fasting plasma glucose and diabetes prevalence since 1980: systematic analysis of health examination surveys and epidemiological studies with 370 country-years and 2.7 million participants. Lancet 2011; 378:31-40.

Davidovitch Z, Nicolay OF, Ngan PW, Shanfeld JL. Neurotransmitters, cytokines and the control of alveolar bone remodeling in orthodontics. Dent Clin North Am. 1988; 32:411-35.

El-Bialy T, Aboul-Azm SF, El-Sakhawy M. Study of craniofacial morphology and skeletal maturation in juvenile diabetics (type I). Am J Orthod Dentofacial Orthop. 2000; 118:189-95.

Emrich, L.J., Shlossman, M., Genco, R.J. Periodontal disease in non-insulin-dependent diabetes mellitus. J Periodontal. Feb 1991; 62(2):123-31.

Ferreira CL, da Rocha VC, da Silva Ursi WJ, De Marco AC, Santamaria M Jr, Santamaria MP, Jardini MAN. Periodontal response to orthodontic tooth movement in diabetes-induced rats with or without periodontal disease. J Periodontol. 2018 Mar; 89(3):341-350.

Freitas, HS, Shaan BD, Silva RB, Okamoto MM, Oliveira-Souza M, Machado UF. Insulin but not phlorizin treatment induces a transient increase in GLUT2 gene expression in the kidney of diabetic rats. Nephron Physiol. 2007; 105:42-51.

Fukushima O, Bekker PJ, Gay CV. Ultrastructural localization of tartrate-resistant acid phosphatase (purple acid phosphatase) activity in chicken cartilage and bone. Am J Anat. 1991 Jul; 191(3):228-36.

Garant PR. Oral Cells and Tissues. Illinois: Quintessence Books. 2003.

Gianelly AA. Force induced changes in the vascularity of the periodontal ligament. Am. J. Orthod., St. Louis. Jan.1969; 55(1): 5-11.

Gianelly AA, Goldman HM. Biologic Basis of Orthodontics. Philadelphia, Lea e Febiger, $1971 ; 414 p$. 
Garlet TP, Coelho U, Silva JS, Garlet GP. Cytokine expression pattern in compression and tension sides of the periodontal ligament during orthodontic tooth movement in humans. Eur J Oral Sci. 2007 Oct; 115(5):355-62.

Giglio MJ, Lama MA. Effect of experimental diabetes on mandibular growth in rats. Eur J Oral Sci. 2001; 109:193-7.

Gomes MF, da Graças Vilela Goulart M, Giannasi LC, Hiraoka CM, de Fátima Santana Melo G, de Sousa AGV, Nóbrega CJP, Zangaro RA, Salgado MAC. Effects of the GaAIAs diode laser $(780 \mathrm{~nm})$ on the periodontal tissues during orthodontic tooth movement in diabetes rats: histomorphological and immunohistochemical analysis. Lasers Med Sci. 2017 Sep; 32(7):1479-1487.

Goodman WG, Hori MT. Diminished bone formation in experimental diabetes. Diabetes. 1984 Sept; 33(9)825-31.

Hie M, Shimono M, Fujii K, Tsukamoto I. Increased cathepsin K and tartrate-resistant acid phosphatase expression in bone of streptozotocin-induced diabetic rats. Bone. 2007 Dec; 41(6):1045-50.

Horowitz MC, Xi Y, Wilson K, Kacena MA. Control of osteoclastogenesis and bone resorption by members of the TNF family of receptors and ligands. Cytokine Growth Factor Rev. 2001 Mar; 12(1):9-18.

Hough S, Avioli LV, Bergfeld MA. Correction of abnormal boné and mineral metabolismo in chronic streptozocin-induced diabetes mellitus in the rat by insulin therapy. Endocrinology. 1981 June; 108(6):2228-34.

Hughes FJ, Turner W, Belibasakis G, Martuscelli G. Effects of growth factors and cytokines on osteoblast differentiation. Periodontol 2000. 2006; 41:48-72.

International Diabetes Federation [internet]. Guideline on Oral Health for people with diabetes. Brussels: IDF, 2009 [cited 2012, jun 11]. Available from site http://www.idf.org/guidelines/diabetes-and-oral-health/guideline.

International Diabetes Federation. IDF Diabetes Atlas, 8th edn. Brussels, Belgium:International Diabetes Federation, 2017. Available from site: http://www.diabetesatlas.org/resources/how-to-cite.html.

Ismail AF, McGrath CP, Yiu CK. Oral health of children with type 1 diabetes mellitus: A systematic review. Diabetes Res Clin Pract. 2015 Jun; 108(3):369-81.

Johnson RB. Morphological characteristics of the depository surface of alveolar bone of diabetic mice. J Periodontal Res. 1992 Jan; 27(1):40-7.

Junod A, Lambert AE, Orci L. Studies of diabetogenic action os streptozocin. Proc Soc Exp Biol Med. 1967 Oct; 126 (1):201-205.

Kanazawa I, Sugimoto T. Diabetes Mellitus-induced Bone Fragility. Intern Med. 2018 May; 18.

Karam J.H. Pancreatic hormones \& Diabetes Mellitus. In: Greenspan, F.S., Strewler, G.J. Basic \& Clinical Endocrinology. 5ed. Stamford Appleton \& Lange. 1997.

Katchburian e Arana, V. Histologia Básica, 1를., São Paulo. Editora Médica Panamericana, 1999; 381p. 
Krishnan V, Davidovitch Z. Cellular, molecular, and tissue-level reactions to orthodontic force. Am J Orthod Dentofacial Orthop. 2006 Apr; 129(4):469.e1-32.

Kubota T, Nomura T, Takahashi T, Hara K. Expression of mRNA for matrix metalloproteinases and tissue inhibitors of metalloproteinases in periodontitis-affected human gingival tissue. Arch Oral Biol 1996; 41:253-262.

Kumar P, Londhe SM, Kotwal A, Mitra R Prevalence of malocclusion and orthodontic treatment need in schoolchildren - An epidemiological study. Med $\mathrm{J}$ Armed Forces India. 2013 Oct; 69(4):369-74.

Kyrkanides S, O'Banion MK, Subtelny JD. Nonsteroidal anti-inflammatory drugs in orthodontic tooth movement: metalloproteinase activity and collagen synthesis by endothelial cells. Am J Orthod Dentofacial Orthop. 2000 Aug; 118(2):203-9.

Lerner UH. Osteoclast formation and resorption. Matrix Biol. 2000. May; 19(2):107-20.

Li X, Zhang L, Wang N, Feng X, Bi LJ. Periodontal ligament remodeling and alveolar bone resorption during orthodontic tooth moviment in rats with diabetes. Diabetes Technol Ther 2010; 12:65-73.

Lu Huafei, Kraut D, Gerstenfeld Lc, Graves DT. Diabetes interferes with the bone formation by affecting the expression of transcription factors that regulate osteoblast differentiation. Endocrinology. 2003; 144:346-352.

Macapanpan LC, Weinmann JP, Brodie AG. Early tissue changes following tooth movements in rats. Angle Orthod. Appleton, 1954 Apr; 24(2):79-95

Maia LG, Alves AV, Bastos TS, Moromizato LS, Lima-Verde IB, Ribeiro MA, Gandini Júnior LG, de Albuquerque-Júnior RL. Histological analysis of the periodontal ligament and alveolar bone during dental movement in diabetic rats subjected to low-level laser therapy. J Photochem Photobiol B. 2014 Jun; 5; 135:65-74.

Maia LG, Monini Ada C, Jacob HB, Gandini LG Jr. Maxillary ulceration resulting from using a rapid maxillary expander in a diabetic patient. Angle Orthod. 2011; 81:546-50.

Masella RS1, Meister M. Current concepts in the biology of orthodontic tooth movement. Am J Orthod Dentofacial Orthop. 2006 Apr; 129(4):458-68.

Meikle MC. The tissue, cellular, and molecular regulation of orthodontic tooth movement: 100 years after Carl Sandstedt. Eur J Orthod 2006; 28:221-140.

Minkin C. Bone acid phosphatase: tartrate-resistant acid phosphatase as a marker of osteoclast function. Calcif Tissue Int. 1982 May; 34(3):285-90.

Mishima N, Sahara N, Shirakawa M, Ozawa H. Effect of streptozotocin-induced diabetes mellitus on alveolar bone deposition in the rat. Arch Oral Biol. 2002; 47:843-849.

Monteiro, Patrícia Maria. Efeito da inalaçãode fumaça de cigarrono processo de remodelação óssea após expansão rápida da maxila, 2017. Tese de doutorado apresentada à Faculdade de Odontologia de Ribeirão Preto, Universidade de São Paulo, Ribeirão Preto, 2012.

Nascimento-Saba CC, Breitenbach MM, Rosenthal D. Pituitary-thyroid axis in short- and long-term experimental diabetes mellitus. Braz J Med Biol Res. 1997; 30:269-74. 
Najeeb S, Siddiqui F, Qasim SB, Khurshid Z, Zohaib S, Zafar MS. Influence of uncontrolled diabetes mellitus on periodontal tissues during orthodontic tooth movement: a systematic review of animal studies. Prog Orthod. 2017 Dec; 18(1):5.

Nakagawa M1, Kukita T, Nakasima A, Kurisu K. Expression of the type I collagen gene in rat periodontal ligament during tooth movement as revealed by in situ hybridization. Arch Oral Biol. 1994 Apr; 39(4):289-94.

Napoli N, Chandran M, Pierroz DD et al (2016) Mechanisms of diabetes mellitus-induced bone fragility. Nat Rev Endocrinol. 2016;153.

Nathan DM and for the DCCT/EDIC Research Group* The Diabetes Control and Complications Trial/Epidemiology of Diabetes Interventions and Complications Study at 30 Years: Overview. Diabetes Care. 2014 Jan; 37(1):9-16.

Nevis ML, Karimbux NY, Weber HP. Wound healing around endosseous implants in experimental diabetes. Int. J. Oral Maxillofac. Implants. 1998 May; 13(5):620-29.

OKADA, Elaine Machado Pingueiro. Efeito do laser de baixa potência após a expansão rápida da maxila, na ativação de regiões cerebrais relacionadas à nocicepção. 2012. Dissertação (Mestrado em Odontopediatria) - Faculdade de Odontologia de Ribeirão Preto, Universidade de São Paulo, Ribeirão Preto, 2012.

Okamoto MM, Anhê GF, Sabino-Silva R, Marques FSF, Freitas HS, Mori RCT et al. Intensive insulin treatment induces insluin resistance in diabetic rats by imparing glucose metabolismrealted mechanisms in muscle and liver. J Endocrinol. 2011;211:1-10.

Okamoto T, de Russo MC. Wound healing following tooth extraction. Histochemical study in rats. Rev Fac Odontol Aracatuba. 1973; 2(2):153-69.

Palermo A, D'Onofrio L, Buzzetti R, Manfrini S, Napoli N. Pathophysiology of Bone Fragility in Patients with Diabetes. Calcif Tissue Int. 2017 Feb; 100(2):122-132.

Plut A, Sprogar S, Drevensek G, et al. Bone remodeling during orthodontic tooth movement in rats with type 2 diabetes. Am J Orthod Dentofacial Orthop. 2015; 148:1017-1025.

Reitan K. Clinical and histological observation on tooth movement during and after orthodontic treatment. Am. J. Orthod. 1967 Oct; 53(10):721-45.

Reitan K, Rygh P. Principios e reações biomecânicas. In Graber TM, Vanarsdall RL. Ortodontia - Principios e técnicas atuais. 2ed. St Louis The Mosby Co. 1994.

Robey PG, Fedarko NS, Hefferan TE, Bianco P, Vetter UK, Grzesik W, Friedenstein A, Van der Pluijm G, Mintz KP, Young MF, et al. Structure and molecular regulation of bone matrix proteins. J Bone Miner Res. 1993 Dec; 8 Suppl 2:S483-7.

Rygh P, Bowling, NS, Sorsa T. Mediated events in diabetes. Ann Ny Acad Sci. June 1999; 878(30):311-334.

Sabino-Silva R, Freitas HS, Lamers ML, Okamoto MM, Santos MF, Machado UF. Na+glucose cotransporter SGLT1 protein in salivary glands: potential involvement in the diabetes-induced decrease in salivary flow. J Membrane Biol. 2009; 228:63-69.

Sanz M, Ceriello A, Buysschaert M, Chapple I, Demmer RT, Graziani F, Herrera D, Jepsen S, Lione L, Madianos P, Mathur M, Montanya E, Shapira L, Tonetti M, Vegh D. Scientific evidence on the links between periodontal diseases and diabetes: Consensus report and 
guidelines of the joint workshop on periodontal diseases and diabetes by the International diabetes Federation and the European Federation of Periodontology. Diabetes Res Clin Pract. 2018 Mar; 137:231-241.

Sawada M, Shimizu N. Stimulation of bone formation in the expanding mid-palatal suture by transforming growth factor-beta 1 in the rat. Eur J Orthod. 1996; 18:169-79.

Sasaki T. Ramamurthy NS, Yu Z. Tetracycline administration understanding mechanically induced boné remodeling and their relevance to orthodontic theory and practice. Am. J. Orthod. Dentofac. Orthod. 1992 Mar; 103(3):212-22.

Schellini SA, Padovani CR, Spadella CT. O rato como modelo experimental do diabetes estudo clínico laboratorial. Rev. Ciencia Biomed. 1995; 16:25-36.

Shyng YC, Devlin H, Sloan P. The effect os streptozotocin-induced experimental diabetes mellitus on calvarial defect. Healing and boné turnover in the rat. Int $\mathrm{J}$ Oral Maxillofac Surg. 2001 Feb; 30 (2):70-74.

Sociedade Brasileira de Diabetes [internet]. Diretrizes da Sociedade Brasileira de Diabetes. Rio de Janeiro: SBD; 2009 jun [cited 2016] avaliable from site http://diabetes.org.br/publicacoes/diretrizes-e-posicionamentos.

Souza LA. Estudo do periodonto do molar de rato diabético submetido à movimentação dentária. Tese de Doutorado em Odontologia. Universidade Estadual paulista, Araraquara, 2001.

Starup-Linde J, Lykkeboe S, Gregersen S, Hauge EM, Langdahl BL, Handberg A, Vestergaard P. Bone Structure and Predictors of Fracture in Type 1 and Type 2 Diabetes. J Clin Endocrinol Metab. 2016 Mar; 101(3):928-36.

Stuani AS. Avaliação da remodelação óssea após disjunção da sutura palatina mediana experimental e laserterapia de baixa potência, em ratos Wistar. Tese de Doutorado, Faculdade de Ciências Farmacêuticas, Universidade de São Paulo, São Paulo. 2012.

Sun J, Du J, Feng W, Lu B, Liu H, Guo J, Amizuka N, Li M. Histological evidence that metformin reverses the adverse effects of diabetes on orthodontic tooth movement in rats. $J$ Mol Histol. 2017 Apr ;48(2):73-81.

Taborsky JR, GJ. The endocrine pâncreas controlo f secretion, In: Patton HD, Fuchs AF, Hile B. Textbook of Physiology. 21ed. Philadelphia W.B. Saunders, 1989.

Ten Cate AR. Histologia Básica. Desenvolvimento, Estructura e Função. 5aㅗ ed., Rio de Janeiro, Guanabara Koogan. 2001; 439p.

Ten Cate histologia oral: desenvolvimento, estrutura e função. NANCI, Antonio. 8. ed. Rio de Janeiro: Elsevier, 2013. A 8ª edição do livro Ten Cate Histologia.

Thrailkill KM, Liu L, Wahl EC, Bunn RC, Perrien DS, Cockrekk GE, Skinner RA, Hogue WR, Carver AA, Fowlkes, Aronson J, Lumpkin CK Jr. Bone formation is impared in a model of type 1 diabetes. Diabetes. 2005; 54:2875-2881.

Um YJ, Jung UW, Kim CS, Bak EJ, Cha JH, Yoo YJ, Choi SH. The influence of diabetes mellitus on periodontal tissues: a pilot study. J Periodontal Implant Sci. 2010; 40:49-55.

Verhaeghe J, Herck EV, Visser WJ. Bone and mineral metabolismo in BB rats with long-term diabetes - Decreased boné turnover and osteoporosis. Diabetes. 1990 Apr.39(4):477-82. 
Villarino ME, Lewicki M, Ubios AM. Bone response to orthodontic forces in diabetic Wistar rats. Am J Orthod Dentofacial Orthop. 2011; 139:S76-S82.

World Health Organization [internet]. Definition, Diagnosis and Classification of Diabetes Mellitus and its Complications. Part 1: Diagnosis and Classification of Diabetes Mellitus. Geneva: WHO,1999 [cited 2012, jun 11]. Available from site http://www.who.int/diabetes/currentpublications/en/.

World Health Organization [internet]. Definition and diagnosis of diabetes mellitus and intermediate hyperglycemia: report of a WHO/IDF consultation. Geneva: WHO; 2006 [cited 2012, jun 11]. Available from site http://www.who.int/diabetes/publications/en/.

World Health Organization [internet]. Global report on diabetes. consultation. Geneva: WHO; 2016. Available from site http://apps.who.int/iris/bitstream/10665/204871/1/9789241565257_eng.pdf.

Weiss RE, Gorn AH, Nimni ME. Abnormalities in the biosynthesis of cartilage and boné proteoglycans in experimental diabetes. Diabetes. 1981 Mar; 30(8):200-207.

Zhang L, Li X, Bi LJ. Alterations of collagen-I, MMP-1 and TIMP-1 in the periodontal ligament of diabetic rats under mechanical stress. J Periodontal Res. 2011; 46:448-455. 

$\mathcal{A}_{\text {nexo }}$ 



\title{
ANEXO 1 - COMITÊ DE ETICA EM PESQUISA
}

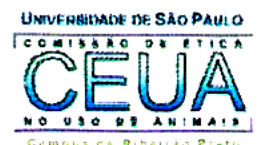

\author{
UNIVERSIDADE DE SÃO PAULO \\ Campus de Ribeirăo Preto \\ Comissão de Etica no Uso de Animais
}

\section{E R T I F I A D O}

Certificamos que o trabalho (Protocolo $n^{\circ}$ 10.1.1026.53.6), intitulado "Avaliação do Processo de Remodelação Óssea Durante Aplicação de Biomecânica Ortopédica em Ratos Diabéticos Tipo 1 - Induzidos. Estudo delular e biomelecular", de autoria de Maria Bernadete Sasso Stuani, por estar de acordo com os Princípios Éticos na Experimentação Animal adotado pela Comissão de Ética no Uso de Animais (CEUA) do Campus de Ribeirão Preto - USP foi aprovado em reunião da CEUA de 07/10/2010.

This is to certify that the work (Protocol number 10.1.1026.53.6), entitled: "Avaliação do Processo de Remodelação Óssea Durante Aplicação de Biomecânica Ortopédica em Ratos Diabéticos Tipo 1 - Induzidos. Estudo delular e biomelecular", by Maria Bernadete Sasso Stuani, is in accordance with the Ethic Principles in Animal Experimentation adopted by Ethic Commission for the Use of Animals (CEUA) of the Campus of Ribeirão Preto - USP, and was approved in the meeting, October 07, 2010.

Ribeirão Preto, 19 de outubro de 2010.

Enita Leiteranisi

Presidente da CEUA

Profa.Dra. Christie Ramos Andrade Leite Panissi

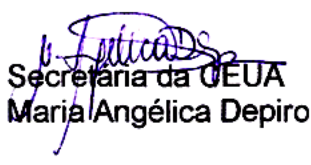

Av. Bandeirantes, 3900 - CEP 14040-900 - Ribeirão Preto - Sáo Paulo Fone: (16) 36024469 - Fax: (16) 36337964 